\title{
PROJECTIONS OF FUTURE CLIMATE FOR EUROPE, URUGUAY AND CHINA WITH IMPLICATIONS ON FORESTRY
}

ARI VENÄLÄINEN

KIMMO RUOSTEENOJA

ILARI LEHTONEN
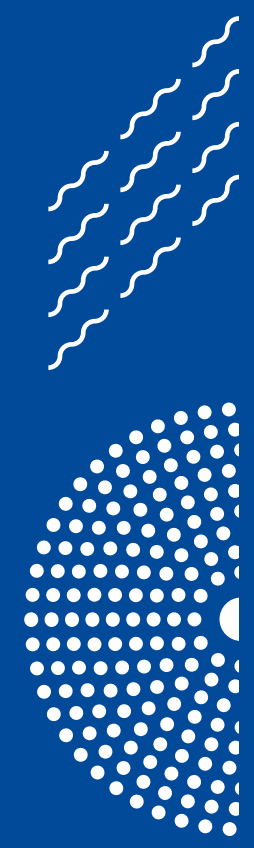
RAPORTTEJA

RAPPORTER

REPORTS

No. 2019:3

PROJECTIONS OF FUTURE CLIMATE FOR EUROPE, URUGUAY AND CHINA WITH IMPLICATIONS ON FORESTRY

Ari Venäläinen

Kimmo Ruosteenoja

Ilari Lehtonen

Ilmatieteen laitos

Meteorologiska institutet

Finnish Meteorological Institute

Helsinki 2019 
ISBN (paperback) 978-952-336-084-6

ISBN (pdf) 978-952-336-085-3

ISSN 0782-6079

Edita Prima Oy

Helsinki, 2019 


\begin{tabular}{|l|l}
\hline Julkaisija & Julkaisusarjan nimi ja numero \\
Ilmatieteen laitos & Raportteja 2019:3 \\
\cline { 2 - 2 } $\begin{array}{l}\text { Erik Palménin aukio 1 } \\
\text { 00101 Helsinki }\end{array}$ & Julkaisuaika \\
Tekijät & Toimeksiantaja \\
Ari Venäläinen, Kimmo Ruosteenoja ja Ilari Lehtonen & UPM-Kymmene Oy \\
\hline Nimeke & \\
Malliennusteisiin perustuva tulevaisuuden ilmasto Euroopassa, Uruguayssa ja \\
Kiinassa sekä ilmastonmuutoksen vaikutuksia metsätalouteen.
\end{tabular}

Tiivistelmä

Raportti tarkastelee odotettavissa olevia ilmastonmuutoksia neljällä UPM-Kymmenen toiminnan kannalta keskeisellä maantieteellisellä alueella: Suomessa, Etelä-Saksassa, Uruguayssa ja Itä-Kiinassa. Lisäksi arvioidaan ilmastonmuutoksen vaikutuksia metsien kasvuun ja käsitellään muutoksesta mahdollisesti seuraavia kasvua häritseviä tekijöitä. Ilmastonmuutosarviot perustuvat 28 maailmanlaajuisella ilmastomallilla tehtyihin ajoihin. Arvioitten pohjana käytetään RCP4.5skenaariota, joka vastaa kohtalaisen voimakkaita kasvihuonekaasujen päästöjä. Ensisijaisesti tarkastellaan vuosisadan puolivälin (jakso 2040-2069) ilmastoa verrattuna 1900-luvun lopun (jakso 1971-2000) tilanteeseen.

Kaikki tutkimuksessa mukana olleet mallit ennustavat lämpötilojen nousevan tulevaisuudessa, joskin lämpiämisen voimakkuus vaihtelee aika paljon mallista toiseen. Monille muille ilmastosuureille, kuten sademäärälle ja auringonsäteilylle, muutoksen suuntaa ei sen sijaan aina voida varmuudella päätellä. Tarkastelluilla alueilla sademäärä kuitenkin pääsääntöisesti kasvaa. Poikkeuksia ovat Etelä-Saksa kesällä ja alkusyksystä, Itä-Kiina loppusyksystä sekä Uruguay eteläisen pallonpuoliskon talvella ja keväällä, joissa sademäärä vähenee. Sielläkin missä sademäärät jonkin verran kasvavat, korkeamman lämpötilan aiheuttama haihdunnan voimistuminen lisää kuivuuden riskiä. Joissakin tapauksissa sekä kovat sateet että kuivat jaksot yleistyvät.

Euroopan metsävarat ovat viime vuosikymmeninä kasvaneet. Erityisesti Pohjois-Euroopan metsät ovat hyötyneet lämpimämmästä ilmastosta ja hiilidioksidipitoisuuden kohoamisesta. Tulevina vuosikymmeninä tämä kehitys ei välttämättä jatku ainakaan entistä tahtia, sillä metsien kasvua saattavat häiritä mm. kuivuus, lisääntyvät metsäpalot ja tuhohyönteisten aiheuttamat vahingot. Pyrittäessä hillitsemään ilmastonmuutosta metsien merkitys hiilen nieluina on tärkeä. Sen tähden mielipiteenvaihto metsien tehokkaasta mutta samalla kestävästä käytöstä jatkunee vilkkaana.

Jos ihmiskunnan pyrkimykset hillitä ilmaston muuttumista osoittautuvat tehokkaiksi, on mahdollista, että tulevat muutokset jäävät selvästi pienemmiksi ja tapahtuvat hitaammin kuin mitä tässä raportissa tarkastellun RCP4.5-skenaarion perusteella olisi odotettavissa. Tämä kuitenkin edellyttää maailmanlaajuisten kasvihuonekaasupäästöjen nopeaa leikkaamista. Hillinnän epäonnistuminen puolestaan johtaisi tässä arvioitua vakavampiin seurauksiin.

Julkaisijayksikkö

Sään ja ilmastonmuutoksen vaikutustutkimus

Luokitus (UDK)

551.515.9, 551.556.1, 551.577.62, 551.583, 632.11, 632.92

ISSN ja avainnimike

0782-6079 Raportteja

\begin{tabular}{l|l|l|}
$\begin{array}{l}\text { ISBN } \\
\text { 978-952-336-084-6 (nide) } \\
\text { 978-952-336-085-3 (pdf) }\end{array}$ & $\begin{array}{l}\text { Kieli } \\
\text { englanti, (tiivistelmä myös } \\
\text { ruotsiksi ja suomeksi) }\end{array}$ & $\begin{array}{l}\text { Sivumäärä } \\
67\end{array}$ \\
\hline $\begin{array}{l}\text { DOI } \\
\text { https://doi.org/10.35614/isbn.9789523360853 }\end{array}$ &
\end{tabular}

Asiasanat

ilmasto, ilmastonmuutos, ilmastoskenaariot, ilmastonmuutokseen sopeutuminen, ilmastonmuutoksen aiheuttamat riskit, metsätalous 


\section{Utgivare}

Meteorologiska institutet

Erik Palméns plats 1

PB 503

00101 Helsingfors

Författare

Ari Venäläinen, Kimmo Ruosteenoja och Ilari Lehtonen

\section{Rubrik}

Den beräknade framtida klimatförändringen i Europa, Uruguay och Kina samt förändringens inverkan på skogsbruket

Sammandrag

Denna rapport behandlar beräknade klimatförändringar inom fyra verksamhetsområden för bolaget UPM-Kymmene: Finland, södra Tyskland, Uruguay och östra Kina. Dessutom diskuteras konsekvenserna av dessa förändringar för skogsbruket, inklusive skogstillväxt, produktivitet och potentiella störningar som förorsakas av klimatförändringen. Klimatprognoserna baserar sig på simulationer utförda med 28 globala klimatmodeller. Analyserna baserar sig på RCP4.5växthusgas-scenariot som representerar måttligt stora utsläpp. Huvudsakligen granskar vi prognoser för perioden 2040-2069 (i jämförelse med perioden 1971-2000).

Alla de analyserade modellerna simulerar högre temperaturer för framtiden. Storleken på uppvärmningen varierar dock ganska mycket bland modellerna. För många andra klimatvariabler, till exempel nederbörden och solstrålningen, kan även tecknet på den framtida förändringen vara osäker. I de regionerna som undersökts är det dock mer sannolikt att nederbörden kommer att öka än minska, med undantag för södra Tyskland på sommaren och under tidig höst, Uruguay på södra halvklotets vinter och vår samt Kina på senhösten. Den stigande temperaturen ökar avdunstningen och risken för torka, även i områden med en måttlig ökning i nederbörd. Under vissa årstider beräknas både intensiva ösregn och torra perioder bli allmännare.

Under de senaste decennierna har skogsresurserna i Europa ökat. Särskilt i Nordeuropa har skogens tillväxt gynnats av det varmare klimatet och den ökande CO2-koncentrationen i atmosfären. Under de kommande decennierna kan denna positiva utveckling, åtminstone delvis, avbrytas på grund av potentiella störningar. Till exempel kan skador orsakas av torka, skogsbränder och skadedjur. Skogens roll som kolsänka är viktig för att begränsa klimatförändringen. Därför kommer en livlig diskussion om den mest gynnsamma och hållbara användningen av skogsresurserna att fortsätta.

Om den globala klimatpolitiken visar sig vara framgångsrik, kan de framtida klimatförändringarna möjligen vara lindrigare än de som förväntas på basen av RCP4.5-scenariot, vilka har diskuterats $\mathrm{i}$ den här rapporten. Detta kräver dock snabba globala begränsningar av växthusgasutsläppen.

Publikationsenhet

Forskning av väder och klimatförändringens effekter

Klassificering (UDK)

$551.515 .9,551.556 .1,551.577 .62,551.583,632.11,632.92$

klimat, klimatscenarier,
Nyckelord anpassning till

klimatförändringen, risker, skogsbruk, global uppvärmning

ISSN ja och serietitel

0782-6079 Rapporter

\begin{tabular}{l|l|l|}
$\begin{array}{l}\text { ISBN } \\
\begin{array}{l}\text { 978-952-336-084-6 (volum) } \\
\text { 978-952-336-085-3 (pdf) }\end{array}\end{array}$ & $\begin{array}{l}\text { Språk } \\
\text { engelska (sammandrag också } \\
\text { på svenska och finska) }\end{array}$ & $\begin{array}{l}\text { Sidantal } \\
67\end{array}$ \\
\hline $\begin{array}{l}\text { DOI } \\
\text { https://doi.org/10.35614/isbn.9789523360853 }\end{array}$
\end{tabular}




\begin{tabular}{|l|}
\hline Publisher \\
Finnish Meteorological Institute \\
Erik Palménin aukio 1 \\
P.O. Box 503 \\
00101 Helsinki, Finland \\
\hline Authors \\
Ari Venäläinen, Kimmo Ruosteenoja and Ilari Lehtonen \\
\hline Tille \\
\hline
\end{tabular}

Report name and number Reports 2019:3

Date

2019

Commissioned by

UPM-Kymmene Oy

Title

Projections of future climate for Europe, Uruguay and China with implications on forestry

Summary

This report deals with projected climatic changes in four areas of operation of the UPMKymmene company: Finland, southern Germany, Uruguay and eastern China. The implications of the projected changes for forestry, including forest growth and productivity and possible climate change induced disturbances, are discussed as well. Climate projections have been derived from the output of 28 global climate models. Analyses focus on the RCP4.5 greenhouse gas scenario that represents an alternative of moderately large emissions. Mainly, projections calculated for the period 2040-2069 (relative to 1971-2000) have been examined.

All the models analyzed simulate higher temperatures for the future. However, the degree of warming varies quite a lot among the models. For many other climate variables, like precipitation and incident solar radiation, even the sign of the future change can be uncertain. Even so, in the regions examined mean precipitation is more likely to increase than decrease, except for southern Germany in summer and early autumn, Uruguay in Southern Hemisphere winter and spring and China in late autumn. Rising temperatures enhance evaporation and increase drought risks despite modest increases in precipitation. In some seasons, both the intense rainfall events and dry periods are projected to become more severe.

In recent decades, forest resources have been increasing in Europe. Especially in Northern Europe, forests have benefitted from the warmer climate and increased $\mathrm{CO}_{2}$ concentration in the atmosphere. During the coming decades, this positive development may at least partly be cancelled due to potentially increasing disturbances for the forest growth. For example, drought, fire and insect pests may cause damage. The role of forests as a carbon sink is an important aspect in the context of climate change mitigation activities, and vivid discussion on the most beneficial and sustainable use of forest resources is foreseen to continue.

If global climate policy proves to be successful, it is possible that future changes in climate will be weaker than those based on the RCP4.5 scenario discussed in this report. However, this requires rapid restrictions of the greenhouse gas emissions globally.

Publishing unit

Weather and Climate Change Impact Research

Classification (UDK)

$551.515 .9,551.556 .1,551.577 .62,551.583,632.11,632.92$

Keywords

climate, climate scenarios, adaptation to climate change, climate risks, forestry, global warming

ISSN and series title

0782-6079 Reports

\begin{tabular}{|c|c|c|}
\hline $\begin{array}{l}\text { ISBN } \\
978-952-336-084-6 \text { (print) } \\
978-952-336-085-3 \text { (pdf) }\end{array}$ & $\begin{array}{l}\text { Language } \\
\text { English (abstract also in } \\
\text { Swedish and Finnish) }\end{array}$ & $\begin{array}{l}\text { Pages } \\
67\end{array}$ \\
\hline
\end{tabular}




\section{PREFACE}

There is a growing need for consistent, scientific and forward-looking information on climate change and its impacts on environment and societies. For a company, it is crucial to understand how its business model, operations and assets could be affected by physical climate change and by transitional aspects such as policies, regulation, technologies and market behaviour.

Understanding the exposures to risks and opportunities of changing climate helps in building the response and taking actions that help adaptation to possible future scenarios. At the same time, it reminds of the urgency of mitigation actions.

To get the best possible information relying on the latest scientific knowledge, UPM engaged with the Finnish Meteorological Institute to study the physical impacts of climate change in its main areas of operations. The study focused especially on company's main raw material source, forest, but takes also into account other aspects such as water availability and weather extremes. 


\section{CONTENTS}

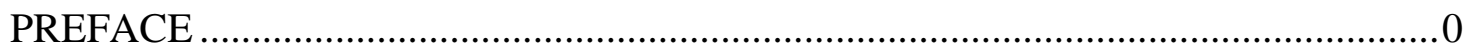

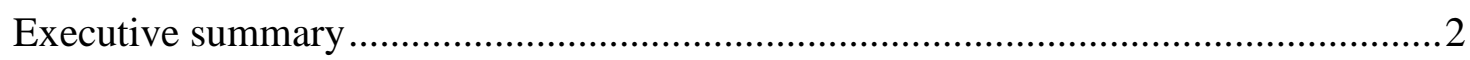

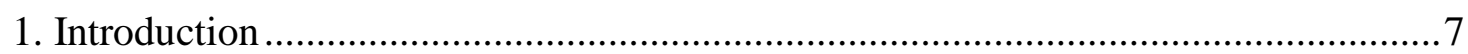

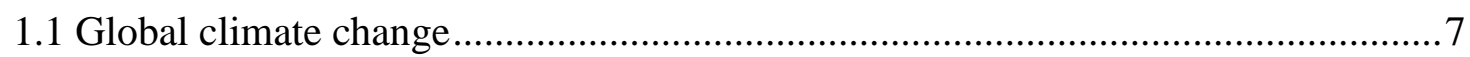

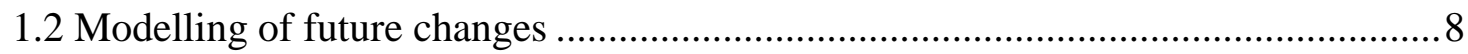

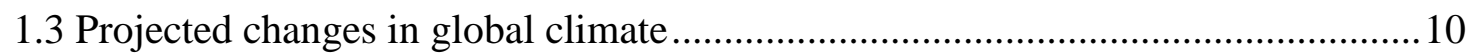

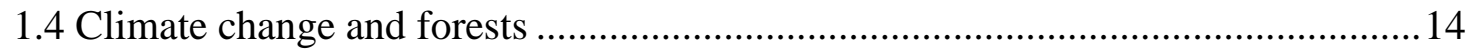

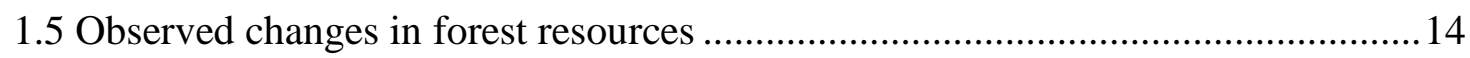

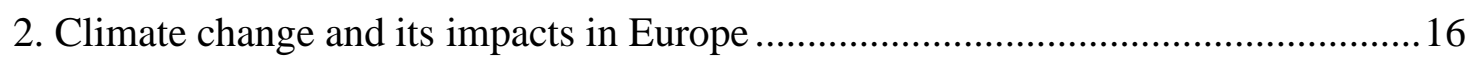

2.1 Overview of projected climate change in Europe .............................................. 16

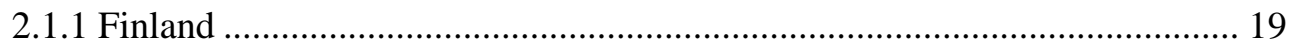

2.1.2 Southern Germany ................................................................................... 26

2.2 Climate change impacts in Europe with focus on forest sector ...............................30

2.3 Climate change induced risks to forests in Europe ................................................. 32

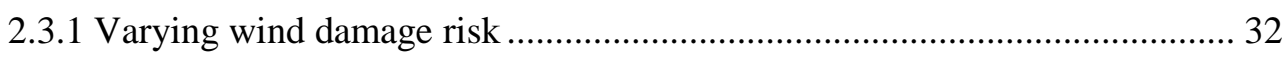

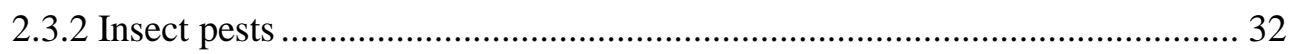

2.3.3 Less soil frost .......................................................................................... 35

2.3.4 Drought leading to higher forest fire risk............................................ 37

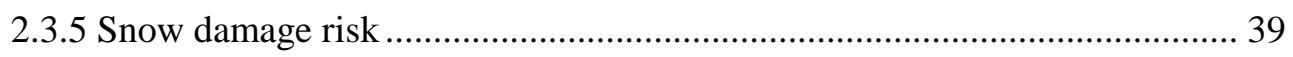

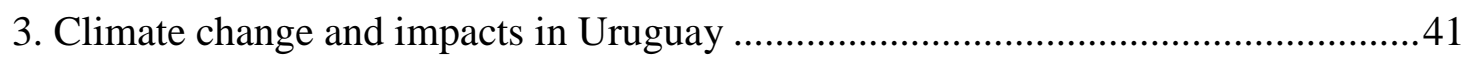

3.1 Projected change of climate in Uruguay .......................................................... 41

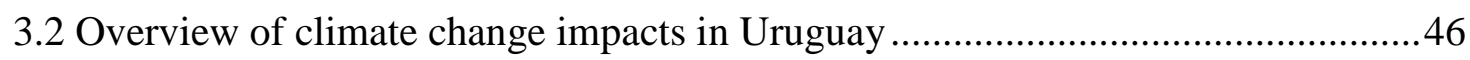

4. Climate change and impacts in China .................................................................49

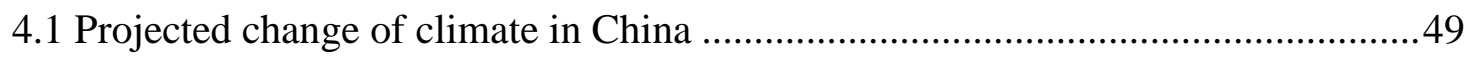

4.2 Impacts on the Yangtze River hydrology ............................................................53

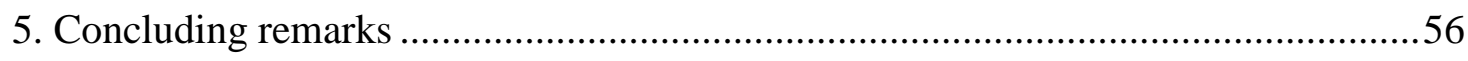

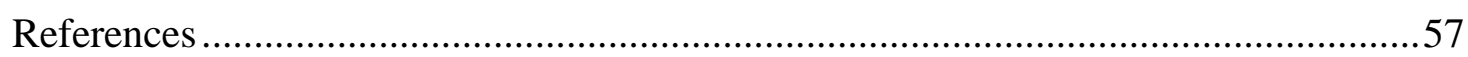

Appendix A: Technical information about the model data and the analysis methods..65

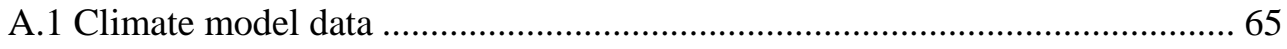

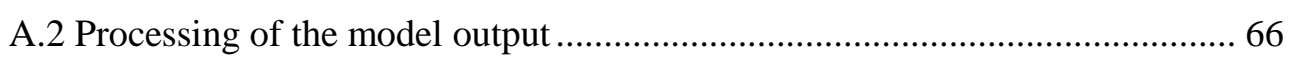




\section{Executive summary}

Discussion on how forests can be utilized in a sustainable way requires information about the ongoing climate change and as well, about the impacts of the change. This report provides estimates for future climatic changes for four key regions that are of interest for the operations of the UPM-Kymmene company: Finland, Southern Germany, Uruguay and Eastern China. Climate projections have been derived from the output of 28 global climate models (GCMs), even though for some climate parameters, data were not available from all the models. In the model runs, three alternative greenhouse gas scenarios have been used, RCP8.5 representing very large, RCP4.5 intermediate and RCP2.6 very small emissions of carbon dioxide and other greenhouse gases. This report mainly examines projections calculated for the period 2040-2069 (relative to 1971-2000) under the RCP4.5 scenario. Potential impacts of the projected changes are discussed as well.

\section{The principal anticipated changes of climate for the focal areas}

If not otherwise stated, the numerical values refer to the multi-model mean changes, the uncertainty interval of the change following in parentheses.

\section{(a) Finland}

- Mean temperature is projected to increase by about $4^{\circ} \mathrm{C}$ (1 to $\left.6^{\circ} \mathrm{C}\right)$ in winter and slightly over $2^{\circ} \mathrm{C}\left(1\right.$ to $\left.4^{\circ} \mathrm{C}\right)$ in summer. Temporal variations of temperature attenuate in winter but remain virtually unchanged in summer. Thermal growing seasons lengthen by 3-4 weeks and the effective temperature sums increase by $\sim 400$ degree days.

- Precipitation increases by $15 \%$ (0 to $30 \%)$ in mid-winter and $5 \%(-15$ to $+25 \%)$ in mid-summer. Consequently, it is nearly certain that mean precipitation increases in winter but in summer the sign of change is uncertain, even though precipitation is more likely to increase slightly than decrease. Events of heavy precipitation intensify. Dry periods are likely to shorten in all seasons apart from summer. Soil moisture declines in spring while in summer the changes are on average fairly modest.

- Wind speeds change little; this holds both for the temporal averages and the high wind speeds.

- Solar radiation received at the surface may decrease in winter and slightly increase in summer, but the inter-model agreement on the sign of change is low.

- Discharge in the Kymmene river increases in winter by 30-40\% (the best estimate of change) and decreases in late summer by about $20 \%$.

\section{(b) Southern Germany}

- Mean temperature is projected to increase by about $2.5^{\circ} \mathrm{C}\left(1\right.$ to $\left.4^{\circ} \mathrm{C}\right)$ in summer and slightly less than $2^{\circ} \mathrm{C}\left(1\right.$ to $\left.3^{\circ} \mathrm{C}\right)$ in the other seasons. Temporal variations of temperature attenuate slightly in winter and remain unchanged at other times.

- Precipitation increases by $10 \%(-10$ to $25 \%)$ in mid-winter and decreases by $5 \%$ (uncertainty interval from -30 to $+20 \%$ ) in late summer. The events of heavy precipitation become more intense, less so in summer than in the other seasons. Dry periods are likely to lengthen in summer and autumn. Soil moisture declines substantially in summer and early autumn.

- Wind speeds are anticipated to change rather little.

- Solar radiation increases in summer by $10 \%$ (0 to $20 \%$ ). In the other seasons the increase is smaller and less robust. Relative humidity declines in late summer by 6 percentage points (uncertainty interval from -12 to $+2 \%$ points). In other seasons the drying of air is weaker. 


\section{(c) Uruguay}

- Monthly mean temperatures are projected to increase by about $1.2-1.5^{\circ} \mathrm{C}(0.5$ to $2^{\circ} \mathrm{C}$ ). Temporal variations of temperature do not alter significantly.

- Precipitation increases by about $10 \%(-15$ to $+40 \%)$ in the Southern Hemisphere autumn and decreases by about $5 \%$ (uncertainty from -25 to $+15 \%$ ) in spring. The events of heavy precipitation become more intense, especially in the Southern Hemisphere autumn. Dry periods are likely to lengthen in winter, perhaps also in spring and summer.

- Wind speeds are most likely to change little.

- Changes in solar radiation and relative humidity are likely to be small as well.

(d) Eastern China

- Mean temperatures are projected to increase by about $2^{\circ} \mathrm{C}\left(1\right.$ to $\left.3^{\circ} \mathrm{C}\right)$ throughout the year. Temporal variations of temperature do not alter significantly.

- Precipitation increases slightly, by $0-10 \%(-15$ to $+25 \%)$, in all seasons except late autumn. The events of intense precipitation become more severe in all seasons. Dry periods are more likely to lengthen slightly than shorten in winter, spring and autumn.

- Wind speeds and relative humidity are likely to change fairly little.

- Solar radiation increases by $2 \%$ (-4 to $8 \%$ ) in winter and by $4 \%$ (-2 to $10 \%)$ in summer. However, this is not a purely climatological phenomenon but also affected by decreasing air pollution.

It is important to note that changes simulated by the individual models diverge substantially. Even if it is virtually certain that the mean temperatures rise in all the regions throughout the year, for many other parameters even the sign of the future change cannot be established firmly. For example, the direction of the precipitation change is generally at least to some extent uncertain, with the exception of Finland in winter, where the likelihood of an increasing precipitation is very high. The present projections correspond to the RCP4.5 scenario. If climate change mitigation measures are effective, the changes will be weaker than assessed in this report. Accordingly, planning of future activities must inevitably be founded on information that is more or less imprecise.

\section{Observed changes in vegetation and forest resources}

- When we look the recent changes in vegetation, the measurements made from satellites indicate greening of the world. The greening trend can be detected especially in China and India. In China, the greening is caused mainly by increasing forest area. However, there are also regions on the globe where the forested area has been declining; for example in Brazil, Democratic Republic of Congo and Indonesia.

- In Europe, the forested area and also growing stock have increased. During the recent years, the increase of forested area in the EU-28 countries has been more than 400,000 ha per year. Concurrently, also the growing stock has increased.

- In Finland, the total increment of forests is currently more than 100 million $\mathrm{m}^{3}$ per year and the total drain of trees (felling and death due to natural causes) more than 80 million $\mathrm{m}^{3}$.

\section{Climate change impacts in Europe}

It is likely that climate change will have both positive and negative effects on wood production and wood supply.

- The positive impacts are due to warmer temperatures, longer growing seasons and fertilization caused by the increased $\mathrm{CO}_{2}$ concentration in the atmosphere. Tree 
growth and productivity are predicted to increase especially at relatively high latitudes and altitudes where low temperatures currently limit the growth.

- The changes may be positive in near future and negative in the mid and long term. The possible increase of meteorological disturbances, which likewise expose forests to biotic damages, may to some extent cancel the climate change-induced productivity increase.

- Increase in the frequency and severity of summer droughts will have an impact on forest fire danger. In the Mediterranean region, large forest fires occur almost every summer, and huge fires are not rare either in the boreal forests of Russia and Canada. The risk of large fires will increase also in northern Europe. Drought may also impact negatively especially the growth of Norway spruce.

- Most of insect pests will benefit from climate change because their development is primarily regulated by air temperature. In Finland, Norway spruce is the most sensitive tree species to climate change, and increasing drought occurrence may weaken its defence against insect pests. In addition to already existing insect pests and fungi, new invasive species can be accidentally introduced by international plant trade.

- In Finland, snow is one of the most important abiotic disturbance agent reducing stand quality in forests. Assessments based on climate model simulations indicate a potentially increasing risk for snow damage in eastern and northern Finland, particularly in the regions of North Karelia, Kainuu, Koillismaa and Lapland. In southern and western Finland, on the other hand, snow loads on tree crowns are projected to decrease.

- Climate change will shorten frozen soil period in northern Europe, making tree harvesting more challenging in locations having poor bearing capacity.

- The overall effect of climate change on forest resources requires continuous multidisciplinary research. It is obvious that intense discussion on the level of sustainable utilization of forest resources related to the EU's land use, land use change and forestry (LULUCF) will continue.

\section{Climate change impacts in Uruguay}

The impacts of climate change in Uruguay are related to sea level rise and other possible hazards such as droughts and floods, heatwaves, hails, storms and tornados. The El Niño - Southern Oscillation phenomenon (ENSO) intensifies inter-annual variations in weather conditions, with higher precipitation during the El Niño years and longer droughts during the La Niña years. If climate change influences the frequency and intensity of this phenomenon, it may cause new challenges to the Uruguay society.

- The tree cover loss between 2001 and 2017 in Uruguay was 327,000 ha whereas the tree cover gain was 499,000 ha. The tree-covered area has thus increased about 170,000 ha during the about 15 -year period. This development can contribute to Uruguay's greenhouse gas balance in a positive way, i.e., the role of forests as a carbon sink increases.

- The largest economic risk caused by sea level rise will be experienced in urbanized areas like the Maldonado-Punta del Este resort and in Montevideo. Sea level rise may cause also other effects like flooding and salinization of lowlands and the lower course of the water flows that discharge along the coast.

- For winter crops, like barley and wheat, the increase of temperature can be harmful but for summer crops like rice, warming can be positive. As well, warmer temperatures may benefit grassland production. Conversely, the increased variability of precipitation is regarded as harmful. 


\section{Climate change impacts on Yangtze River hydrology in China}

- Several published studies indicate that climate change will cause a general increase in annual streamflow at Yangtze River. The increase is predicted to occur mainly during the warm season whereas during the cool season the streamflow can even decrease. The increased fluctuations in rainfall can increase the variability of maximum streamflows and flooding events.

- Glaciers at the source region of Yangtze River are shrinking. This leads to an increase of water resources over the short term, but on the long-run the impacts of melting glaciers can be negative and decline water resources.

- Besides rainfall patterns and the glacial melting, the erosion caused by the sediment starvation and the sea level rise are influencing the hydrological conditions near the Yangtze River delta. River damming and soil conservation decrease sediment discharge, and in conjuction with the sea level rise, this increases the erosion potential of the delta area. As well, saltwater intrusion and storm surge intensity in the delta area may increase. 
Table 1. Climate change projections and impacts of climate change under greenhouse gas concentration pathways RCP2.6, RCP4.5 and RCP8.5. Information given in items 1 and 2 has been extracted from IPCC. Items 5-9 are derived from the findings of the present report. In items 3-4, some examples of risks have been selected that the authors regard as particularly severe. The reported degree of severity may vary to some extent in literature.

\begin{tabular}{|c|c|c|c|}
\hline & RCP8.5 & RCP4.5 & RCP2.6 \\
\hline $\begin{array}{l}\text { 1. Global warming relative to } \\
\text { the preindustrial level. }\end{array}$ & $\begin{array}{l}2.7^{\circ} \mathrm{C} \text { by the } 2050 \mathrm{~s} \\
4.2^{\circ} \mathrm{C} \text { by the } 2080 \mathrm{~s}\end{array}$ & $\begin{array}{l}2.1^{\circ} \mathrm{C} \text { by the } 2050 \mathrm{~s} \\
2.6^{\circ} \mathrm{C} \text { by the } 2080 \mathrm{~s}\end{array}$ & $\begin{array}{l}1.7^{\circ} \mathrm{C} \text { by the } 2050 \mathrm{~s} \\
1.8^{\circ} \mathrm{C} \text { by the } 2080 \mathrm{~s}\end{array}$ \\
\hline $\begin{array}{l}\text { 2. Global sea level rise from } \\
\text { the } 1990 \text { s to } 2090 \text { s. In brackets } \\
\text { there are likely ranges for } \\
\text { projections. }\end{array}$ & $\begin{array}{l}63 \mathrm{~cm} \\
(45 \mathrm{~cm}-82 \mathrm{~cm})\end{array}$ & $\begin{array}{l}47 \mathrm{~cm} \\
(32 \mathrm{~cm}-63 \mathrm{~cm})\end{array}$ & $\begin{array}{l}40 \mathrm{~cm} \\
(26 \mathrm{~cm}-55 \mathrm{~cm})\end{array}$ \\
\hline 3. Impacts on global scale & $\begin{array}{l}\text { Significant fraction of plant and } \\
\text { animal species may be extinct. } \\
\text { Living conditions in many } \\
\text { developing countries deteriorate } \\
\text { drastically. Risk of massive } \\
\text { immigration into wealthy countries. }\end{array}$ & $\begin{array}{l}\text { Widespread extinction of species but } \\
\text { less severe than under RCP8.5. } \\
\text { Increasingly severe societal problems } \\
\text { in many developing countries. } \\
\text { Immigration pressure into wealthy } \\
\text { countries is likely to increase. }\end{array}$ & $\begin{array}{l}\text { Regional destructions of } \\
\text { ecosystems. Societal problems } \\
\text { exacerbate in some developing } \\
\text { countries. Immigration } \\
\text { pressure into wealthy countries } \\
\text { may increase. }\end{array}$ \\
\hline $\begin{array}{l}\text { 4. Risks of irreversible } \\
\text { changes (examples) }\end{array}$ & $\begin{array}{l}\text { Greenland and Antarctic Ice Sheet } \\
\text { losing mass. Rapid Arctic summer } \\
\text { sea-ice loss. Amazon forest and } \\
\text { boreal forest dieback }\end{array}$ & $\begin{array}{l}\text { Greenland and Antarctic Ice Sheet } \\
\text { losing mass. Frequent Arctic summer } \\
\text { sea-ice loss. }\end{array}$ & $\begin{array}{l}\text { Occasional Arctic summer } \\
\text { Sea-ice loss. }\end{array}$ \\
\hline 5. Impacts on Finnish forests & $\begin{array}{l}\text { Spruce forests suffer seriously from } \\
\text { drought in southern and central } \\
\text { Finland. Forest fire danger increases } \\
\text { manifold. Increased snow damage } \\
\text { risk in northern and reduced in } \\
\text { southern parts of country. Seriously } \\
\text { increased biotic }{ }^{2} \text { damage risk. } \\
\text { Largely reduced soil frost hampers } \\
\text { forest harvesting. }\end{array}$ & $\begin{array}{l}\text { Spruce forests suffer from drought in } \\
\text { southern and central Finland. Pine and } \\
\text { birch benefit of change. Increased } \\
\text { forest fire danger and biotic damage } \\
\text { risk. Reduced soil frost hampers forest } \\
\text { harvesting. }\end{array}$ & $\begin{array}{l}\text { Excluding spruce, forests } \\
\text { benefit from the higher } \mathrm{CO}_{2} \\
\text { concentration and longer } \\
\text { growing season. Slightly } \\
\text { increased forest fire danger } \\
\text { and biotic damage risk. }\end{array}$ \\
\hline $\begin{array}{l}\text { 6. Annual mean temperature } \\
\text { changes in eastern-central } \\
\text { Finland relative to } 1971-2000 \text {. }\end{array}$ & $\begin{array}{l}\text { About } 3.8^{\circ} \mathrm{C} \text { by the } 2050 \text { s and nearly } \\
6^{\circ} \mathrm{C} \text { by the } 2080 \mathrm{~s} \text {. In late- } 21^{\text {st }} \\
\text { century, annual mean temperatures } \\
\text { similar to those in northern Germany } \\
\text { in recent past. }\end{array}$ & $\begin{array}{l}\text { About } 2.8^{\circ} \mathrm{C} \text { by the } 2050 \mathrm{~s} \text { and } 3.6^{\circ} \mathrm{C} \\
\text { by the } 2080 \mathrm{~s} \text {. In late- } 21^{\text {st }} \text { century, } \\
\text { annual mean temperatures similar to } \\
\text { those in southernmost Sweden in } \\
\text { recent past. }\end{array}$ & $\begin{array}{l}\text { About } 2.3^{\circ} \mathrm{C} \text { for both periods. } \\
\text { In late- } 21 \mathrm{st} \text { century, mean } \\
\text { temperatures similar to those } \\
\text { of the southern coast of } \\
\text { Finland in recent past. }\end{array}$ \\
\hline $\begin{array}{l}\text { 7. Changes in southern } \\
\text { Germany by the } 2050 \text { s. }\end{array}$ & $\begin{array}{l}\text { Annual mean warming } 2.7^{\circ} \mathrm{C} \\
\text { relative to } 1971-2000 . \\
\text { drought risk in summer. }\end{array}$ & $\begin{array}{l}\text { Annual mean warming } 2.0^{\circ} \mathrm{C} \text { relative } \\
\text { to } 1971-2000 \text {. Drought risk in summer. }\end{array}$ & $\begin{array}{l}\text { Annual mean warming } 1.6^{\circ} \mathrm{C} \\
\text { relative to } 1971-2000 . \\
\text { Occasional drought risk in } \\
\text { summer. }\end{array}$ \\
\hline $\begin{array}{l}\text { 8. Changes in Uruguay by the } \\
2050 \text { s. }\end{array}$ & $\begin{array}{l}\text { Annual mean warming } 1.8^{\circ} \mathrm{C} \\
\text { relative to } 1971-2000 \text {. Increasing } \\
\text { risk of floods in Southern } \\
\text { Hemisphere summer and autumn }\end{array}$ & $\begin{array}{l}\text { Annual mean warming } 1.3^{\circ} \mathrm{C} \text { relative } \\
\text { to } 1971-2000 \text {. Minor increase in flood } \\
\text { risk. }\end{array}$ & $\begin{array}{l}\text { Annual mean warming } 0.9^{\circ} \mathrm{C} \\
\text { relative to } 1971-2000 .\end{array}$ \\
\hline $\begin{array}{l}\text { 9. Changes in eastern China by } \\
\text { the } 2050 \text { s. }\end{array}$ & $\begin{array}{l}\text { Annual mean warming } 2.7^{\circ} \mathrm{C} \\
\text { relative to } 1971-2000 \text {. Increasing } \\
\text { occurrence of floods in Yangtze } \\
\text { river in summer. }\end{array}$ & $\begin{array}{l}\text { Annual mean warming } 2.0^{\circ} \mathrm{C} \text { relative } \\
\text { to } 1971-2000 \text {. Increasing occurrence } \\
\text { of floods in Yangtze river but not as } \\
\text { severe as under RCP8.5. }\end{array}$ & $\begin{array}{l}\text { Annual mean warming } 1.6^{\circ} \mathrm{C} \\
\text { relative to } 1971-2000 \text {. Some } \\
\text { increase in flood occurrence in } \\
\text { Yangtze river. }\end{array}$ \\
\hline
\end{tabular}

${ }^{1}$ Estimates are derived from IPCC; much higher estimates have been given in other sources. In the very recently published draft of IPCC Special Report Ocean and Cryosphere, the estimated rise under RCP8.5 is about $20 \mathrm{~cm}$ higher but under RCP2.6 about the same as given here.

${ }^{2}$ For example bark beetle and root rot 


\section{Introduction}

\subsection{Global climate change}

Earth and its atmosphere have been existing for more than four milliard years, and the climate of our planet has fluctuated all this time. Over the majority of the time, climate has been rather warm, and no wide ice sheets have occurred. These long warm periods have been interspersed by cool epochs that typically have lasted tens or hundreds millions years. Cool climate epochs are characterized by widespread continental glaciation.

Global climate is fundamentally determined by the heat balance of the planet. The principal source of energy is solar radiation. About $70 \%$ of the incoming solar radiation is absorbed by the Earth, and the remaining $30 \%$ is reflected back into the space without being converted into heat. The energy input from the absorption of solar radiation is balanced by the emission of thermal infrared radiation into the space. In low latitudes between about $40^{\circ} \mathrm{S}$ and $40^{\circ} \mathrm{N}$, the radiation balance is positive with solar absorption exceeding the emission of thermal radiation; in latitudes higher than $40^{\circ}$ the situation is vice versa. The surplus of heat is transported from the equatorial areas into polar latitudes by ocean currents and atmospheric circulation. Local climate in the various regions of the Earth is strongly influenced by the oceanic and atmospheric circulation. For example, in northern Europe climate is quite mild compared with the conditions prevailing in these latitudes on average. This is due to the warm oceanic currents that transport heat into the north Atlantic area and, in particular, the prevailing westerly winds that advect the heat into north-western Eurasia.

Thermal infrared radiation emitted by the surface of the Earth does not penetrate into the space directly, but a majority of the radiation is absorbed and then re-emitted by the atmosphere. This property of the atmosphere is termed the greenhouse effect. The principal greenhouse gases are water vapour and carbon dioxide, with methane, ozone, nitrous oxide and several other gases having a smaller but still nonnegligible importance. Without the greenhouse effect, the average surface temperature of the Earth would be about $-18^{\circ} \mathrm{C}$; thanks to these gases, however, the present global mean temperature is about $+14^{\circ} \mathrm{C}$, i.e., more than $30^{\circ} \mathrm{C}$ higher than in the absence of the greenhouse effect.

Natural climate changes occurred in the climate history of the Earth have been caused by several factors: long-term changes in solar radiance, changes in the composition of the atmosphere, continental drift, volcanic eruptions, etc. In the early times of the existence of the Earth, solar radiation was substantially weaker than presently. The resulting deficit in the heath input was compensated by a strong greenhouse effect, caused by the very high concentration of carbon dioxide in the atmosphere. For the relatively cool climate that has prevailed during the past few million years, two (potentially complementary) main explanations have been suggested. First, the Antarctic continent, previously in connection with the other continents of the Southern Hemisphere, was isolated due to continental drift about 50 million years ago. This allowed a cold ocean current to begin to circulate around the continent. The transport of heat into southern high latitudes declined drastically, which was followed by a gradual glaciation of the Antarctica. The high albedo (the ability to reflect solar radiation) of the ice-covered surface increased the portion of solar radiation that was reflected into the space, thus reducing the production of heat by the absorption of solar radiation. Secondly, the development of the Himalayan mountain range brought certain minerals, especially calcium silicate, to the surface in contact with the air. Such minerals can react with carbon dioxide, thus reducing the concentration of that gas in the atmosphere. These changes took place in time scales of millions of years.

During the latest million years, climatic fluctuations have been strong. Ice ages and milder interglacial periods have followed one another in time scales of 10000 to 100000 
years. The glacial-interglacial variations are primarily induced by periodic changes in the orbit and axis of rotation of the Earth. Furthermore, the variations are amplified by contemporaneous changes in the atmospheric carbon dioxide concentration.

For a reader interested in natural climate variations more deeply, exoteric literature is available abundantly. In particular, the well-written book of Eronen (1991) can be recommended.

During the past few centuries and, in particular, during the recent decades, the main drivers of global climate change have been the human-induced emissions of greenhouse gases and aerosol precursors. The concentration of carbon dioxide has increased from the pre-industrial level of $280 \mathrm{ppm}$ (parts per million in volume) to $410 \mathrm{ppm}$ in 2019. Simultaneously, the concentration of methane has more than doubled. On the other hand, small aerosol particles, especially sulphates, originating from anthropogenic emissions act to increase the reflection of solar radiation into the space and thus have a cooling effect. Until presently, increased aerosol forcing has partially compensated global warming caused by the strengthening of the greenhouse phenomenon. In the long term, however, increasing greenhouse gas concentrations will dominate owing to the long atmospheric lifetime of the greenhouse gas emissions. While aerosol particles are washed out from the atmosphere within a few weeks, present emissions of carbon dioxide influence the atmospheric composition for several millenia. The major source of carbon dioxide is the combustion of fossil fuels, but deforestation and other changes in the land use have some importance as well.

\subsection{Modelling of future changes}

Compared to the pre-industrial era, global mean temperature has risen by about one degree. Future climatic changes can been assessed by examining simulations performed with climate models. A climate model is a simulation tool that is founded on the physical laws governing the different components of the climate system (in particular, atmosphere, oceans, soil, vegetation and cryosphere) and their mutual interactions. The operational principle of climate models is described in more detail in the textbook chapter of Ruosteenoja (2011), for instance. Because of limitations in computational capacity, the models inevitably describe the climate system in an approximative way.

Presently, several tens of different climate models have been developed. Because of the different approximations employed in the models, simulated future changes diverge across the models. In order to obtain the most realistic picture of the anticipated future changes and their uncertainties, it is therefore necessary to study a multitude of models rather than relying on a single or a few ones. In the calculations of this report, we have utilized the output of 28 global climate models (GCMs) participating in Phase 5 of the Coupled Model Intercomparison Project (Table A1 in the Appendix of this report).

Future emissions and the resulting atmospheric concentrations of the various greenhouse gases cannot be known in advance. Therefore, multiple alternative greenhouse gas scenarios have been developed, founded on different estimates of the future evolution of world population, energy consumption, land use, energy production technologies and other factors that determine the future emissions. In the present report, we examine three Representative Concentration Pathway (RCP) greenhouse gas scenarios, RCP2.6 representing very small, RCP4.5 moderate and RCP 8.5 very large emissions. The number after the acronym refers to radiative forcing, i.e., the imbalance between the solar radiation absorbed and the thermal infrared radiation emitted by the Earth. For example, if the RCP4.5 scenario were realized, the positive (=warming) globally averaged radiative forcing at the end of the 21 st century would be $4.5 \mathrm{~W} / \mathrm{m}^{2}$. The philosophy behind the RCP forcing scenarios is discussed in detail in van Vuuren et al. (2011). 
The evolution of the emissions and atmospheric concentrations of the most important greenhouse gas, carbon dioxide, under the three RCP scenarios is shown in Figure 1.1. Under the RCP8.5 scenario, emissions would continue to increase throughout the $21 \mathrm{st}$ century, ultimately three-folding compared to the level that prevailed in 2000 , and the concentration of $\mathrm{CO}_{2}$ would approach $1000 \mathrm{ppm}$ by 2100. According to the other two scenarios, global emissions start to decline during this century. If the RCP4.5 scenario is realized, the $\mathrm{CO}_{2}$ concentration stabilizes close to $540 \mathrm{ppm}$, a level about double that in the pre-industrial era. Under the most environmental-friendly RCP2.6 scenario, the concentrations start to diminish slowly after mid-century. The RCP2.6 scenario is likely to meet the targets of the Paris Agreement. In addition to carbon dioxide, the RCP scenarios describe future emissions and atmospheric concentrations of several other greenhouse gases as well as the precursors of aerosol particles.
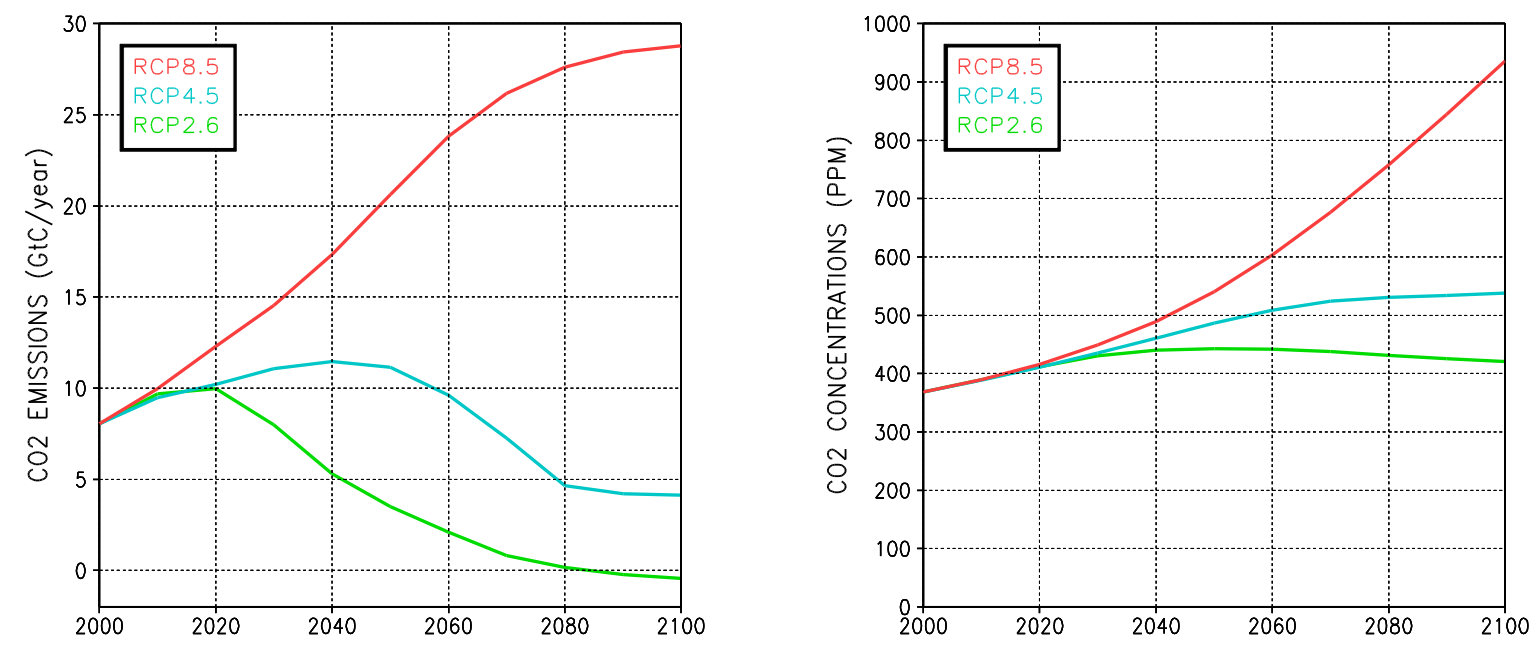

Figure 1.1: Temporal evolution of the global emissions (gigatonnes of carbon per year; left panel) and atmospheric concentrations (parts per million in volume; right panel) of carbon dioxide in 2000-2100 according to three RCP scenarios; see the legend.

In this report, projections of multiple climate quantities (temperature, precipitation, etc.) for the target areas (Finland, southern Germany, Uruguay and eastern China) are first given in multi-model mean changes. The multi-model mean can be regarded as the most probable or "best estimate" projection for the future. Projected changes are expressed relative to the baseline-period 1971-2000 mean. Time series of the 30-year running mean change, covering the time span from the 2000s to the 2080s, are depicted separately for all three RCP scenarios. The spatial distributions of the change are only shown for the period 2040-2069 under RCP4.5.

In addition to the multi-model mean projections, we present 5 to $95 \%$ uncertainty intervals of the change for the key variables. According to the model data analyzed here, there is a $90 \%$ probability that the projected change falls within this interval. Correspondingly, probabilities for the change being below the lower limit or above the upper limit of the interval are both $5 \%$. Of course, as simulations performed with new model generations become available in the future, the climate change estimates will have to be modified.

To further elucidate changes in precipitation climate, we examine model-based changes in two precipitation indices. Heavy precipitation events are considered by studying the maximum precipitation falling within a single day. For drought stress, we analyze the lengths of the periods of consecutive dry days, with precipitation $<1$ millimeter/day in every day within the period. The exact definition of these indices is given in Lehtonen and Jylhä (2019). Unlike projections for the other quantities, owing to data 
availability the projections for the precipitation indices are given for the period 2071-2100 rather than 2040-2069. Since climate change will most likely be more ample for the more distant than the earlier period, changes in the indices are thus not entirely comparable with the projections given for the other climate quantities. In many cases, changes in the precipitation indices vary materially across the models. Therefore, we do not fit any statistical distribution in the data but visualize the inter-model scatter of the change in the indices by quantile plots.

For Finland, we likewise examine changes in the thermal growing season (onset, termination and degree days), changes in strong wind speeds and soil moisture (analyzed soil moisture data is not available outside of Europe), and projections for the discharge in the Kymmene river. The thermal growing season, consisting of those days when the daily mean temperature is above $+5^{\circ} \mathrm{C}$, is a relevant measure of growing conditions only in areas of a cool climate.

Additional technical information about the model data and the analysis methods is presented in the Appendix of this report.

\subsection{Projected changes in global climate}

The simulated evolution of global-mean warming under the three RCP scenarios is shown in Figure 1.2. Recall that in this figure (as well as elsewhere in this report) the changes are expressed relative to the temporal mean of the period 1971-2000, before which global mean temperature had already increased by about $0.5^{\circ} \mathrm{C}$. Under RCP8.5, global warming would continue throughout the century without any sign of deceleration, the global mean temperature increasing by about $4^{\circ} \mathrm{C}$ in 100 years. If the RCP4.5 scenario is realized, the corresponding increase would be about $2^{\circ} \mathrm{C}$ and under RCP2.6, slightly above $1{ }^{\circ} \mathrm{C}$. Considering the global warming already taken place before the baseline period 1971-2000, the latter alternative would correspond to a warming slightly less than $2^{\circ} \mathrm{C}$ compared to the pre-industrial level.

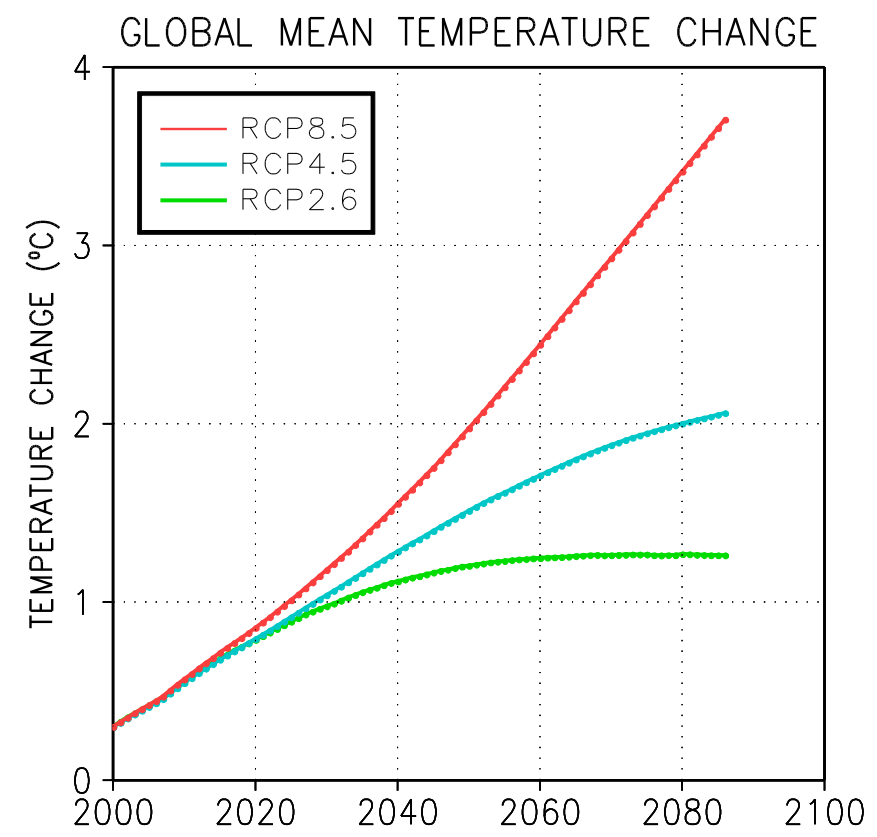

Figure 1.2: Projected changes in global mean annual temperature $\left(\right.$ in $\left.{ }^{\circ} \mathrm{C}\right)$ for the period 2000-2085 (relative to 1971-2000) under the RCP2.6, RCP4.5 and RCP8.5 scenarios (see the legend); a mean of the simulations performed with 28 global climate models. Prior to 1971-2000, global mean temperature had increased about $0.5^{\circ} \mathrm{C}$ compared to the preindustrial level. 
The projections depicted in Figure 1.2 represent a mean over the 28 climate models examined (Table A1 in the Appendix). In practice, the simulated rate of warming diverges across the models; this topic will be discussed later in this report when considering regional climate projections. Anyhow, it is evident that, regardless of the future reductions of emissions, warming will continue during the next few decennia, and mankind must endeavour to adjust to the anticipated change. On the other hand, the vigour of climate policy decisively affects the degree of warming that the next generations of mankind have to experience during the second half of this century and later on.

In particular, in the long term the RCP8.5 scenario would lead to catastrophically large changes in climate, environment and society, especially in many under-developed countries. For example, in wide areas of the world, agricultural production would suffer severely from overly high temperatures and shortage of water. Worsening living conditions in the third world would induce a massive migration pressure into wealthier countries. Migration and actions to prevent it would hazard societal stability in industrialized countries as well. Also, the sea level rise is substantially more rapid under RCP8.5 than under the other RCP scenarios, particularly after 2100. Fortunately, considering the present advances in climate policy, the RCP8.5 scenario seems to be quite an unlikely alternative for long-term global evolution. On the other hand, the RCP2.6 scenario would require drastic reductions in global emissions as early as in the 2020s (Figure 1.1), which does not sound very easy at present. Therefore, we have deemed RCP4.5 the most realistic alternative for the evolution by the mid-century, and the projections will mainly be presented for this scenario.

The geographical distributions of projected changes in temperature and precipitation for the mid-21st century are shown in Figures 1.3 and 1.4. Very intense warming is simulated for northern polar areas in winter; this is related to the partial disappearance of wintertime ice cover. Besides, land areas with scant or decreasing precipitation warm rather rapidly, especially in summer. In these areas, latent heat consumed for evaporation of water does not restrict warming materially. Conversely, in ocean areas south of Iceland, warming is modest since weakening of the warm ocean current partially cancels the influence of global warming.

Precipitation is projected to increase in equatorial areas, mainly over oceans, and in high latitudes especially in winter. Decreasing precipitation totals are simulated for lowlatitude areas at both sides of the equator. All the projected changes in Figures 1.3 and 1.4 correspond to multi-model means, and consequently the projections are subject to intermodel differences. This topic will be discussed below when presenting projections for focal areas.

The geographical pattern of change in temperature and precipitation is qualitatively very similar for all three RCP scenarios and also for the less and more distant future periods (Figures 5-6 and S4-S7 of Ruosteenoja et al., 2016a), the amplitude of the response being approximatively proportional to the global mean temperature increase (Figure 1.2). One can thereby approximate the local warming or precipitation change for any scenario and time horizon by multiplying the change shown in the map 1.3 or 1.4 by the ratio of global temperature increase for that period and scenario to the global warming corresponding to the period 2040-2069 and the RCP4.5 scenario.

An illustrative example: according to Figure 1.3, winter temperatures in Northern Ostrobotnia in Finland would rise by about $4.0^{\circ} \mathrm{C}$ by the period $2040-2069$ under RCP4.5. If one is interested to assess the corresponding temperature increase for the 2070s under $\mathrm{RCP} 2.6$, for instance, one should first find the required global temperature increases in Figure 1.2: $1.27^{\circ} \mathrm{C}$ for the 2070 s under RCP2.6 and $1.61^{\circ} \mathrm{C}$ for the 2050 s under RCP4.5. The ratio of the former to the latter is $1.27 / 1.61=0.79$. By multiplying the above- 
mentioned warming extracted from the map by this ratio, one obtains an approximation for the inquired local temperature increase: $\mathrm{DT} \approx 0.79 \times 4.0^{\circ} \mathrm{C} \approx 3.2^{\circ} \mathrm{C}$.

Figure 1.2 indicates that global mean warming between the periods 1971-2000 and 2040-2069 under RCP4.5 is likely to be about $1.5^{\circ} \mathrm{C}$, corresponding to a temperature increase of close to $2^{\circ} \mathrm{C}$ when compared with the pre-industrial climate. Accordingly, if the objective to restrain the global mean temperature increase to $1.5^{\circ} \mathrm{C}$ relative to the preindustrial level were achieved, the geographical pattern of the change would be similar to that in Figure 1.3 or 1.4 but the amplitude would be somewhat weaker (by a factor of $\approx$ $0.75)$. Even so, bearing in mind that the global temperature has already increased by about $1^{\circ} \mathrm{C}$, avoiding the exceedance of the $1.5^{\circ} \mathrm{C}$ threshold is an extremely challenging target.

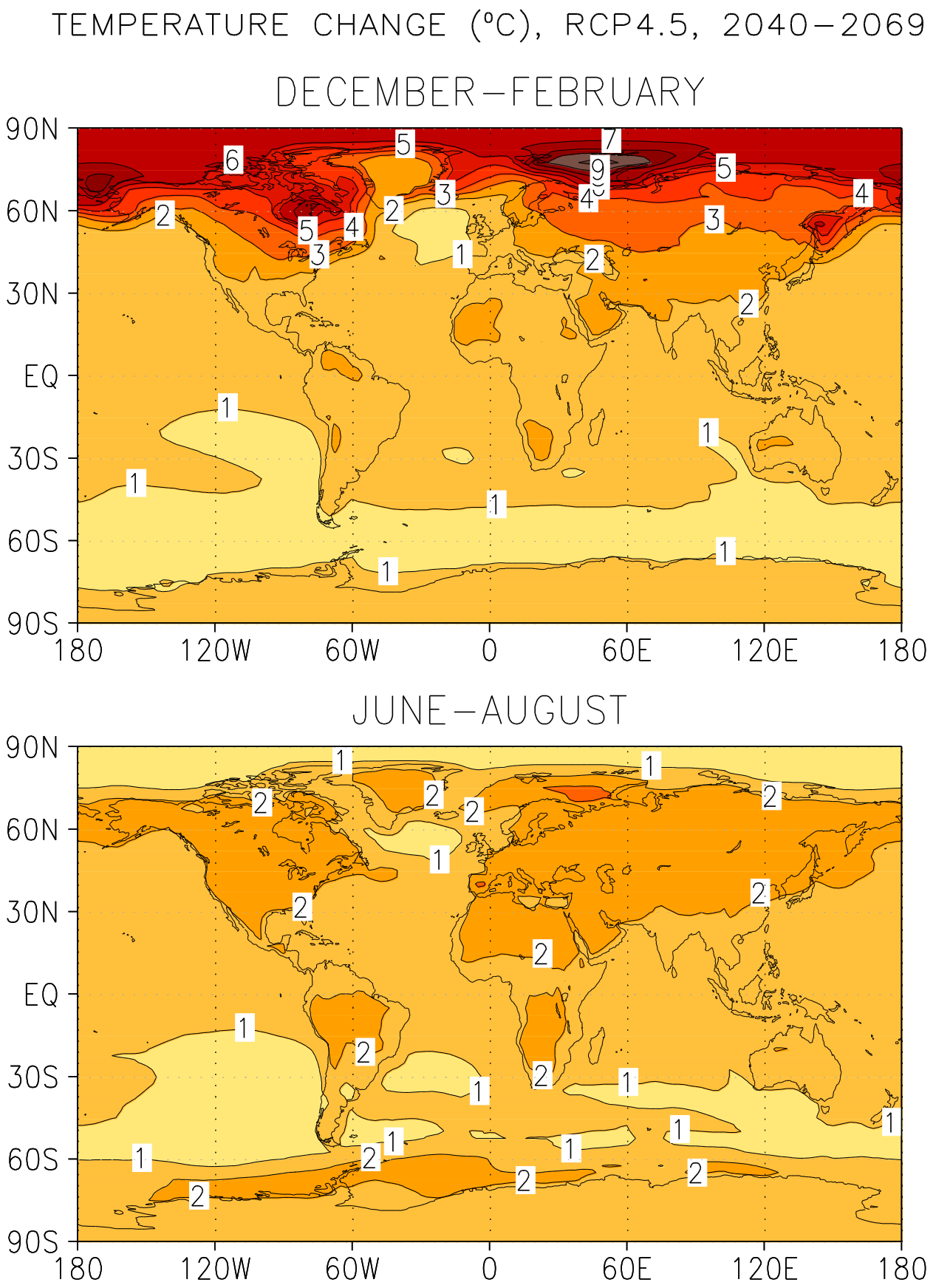

Figure 1.3: Projected change in mean temperature $\left(\right.$ in ${ }^{\circ} \mathrm{C}$ ) in December-February (upper panel) and June-August (lower panel) from the period 1971-2000 to 2040-2069 under the RCP4.5 scenario; a mean of the simulations performed with 28 climate models. 
PRECIPITATION CHANGE (\%), RCP4.5, 2040-2069

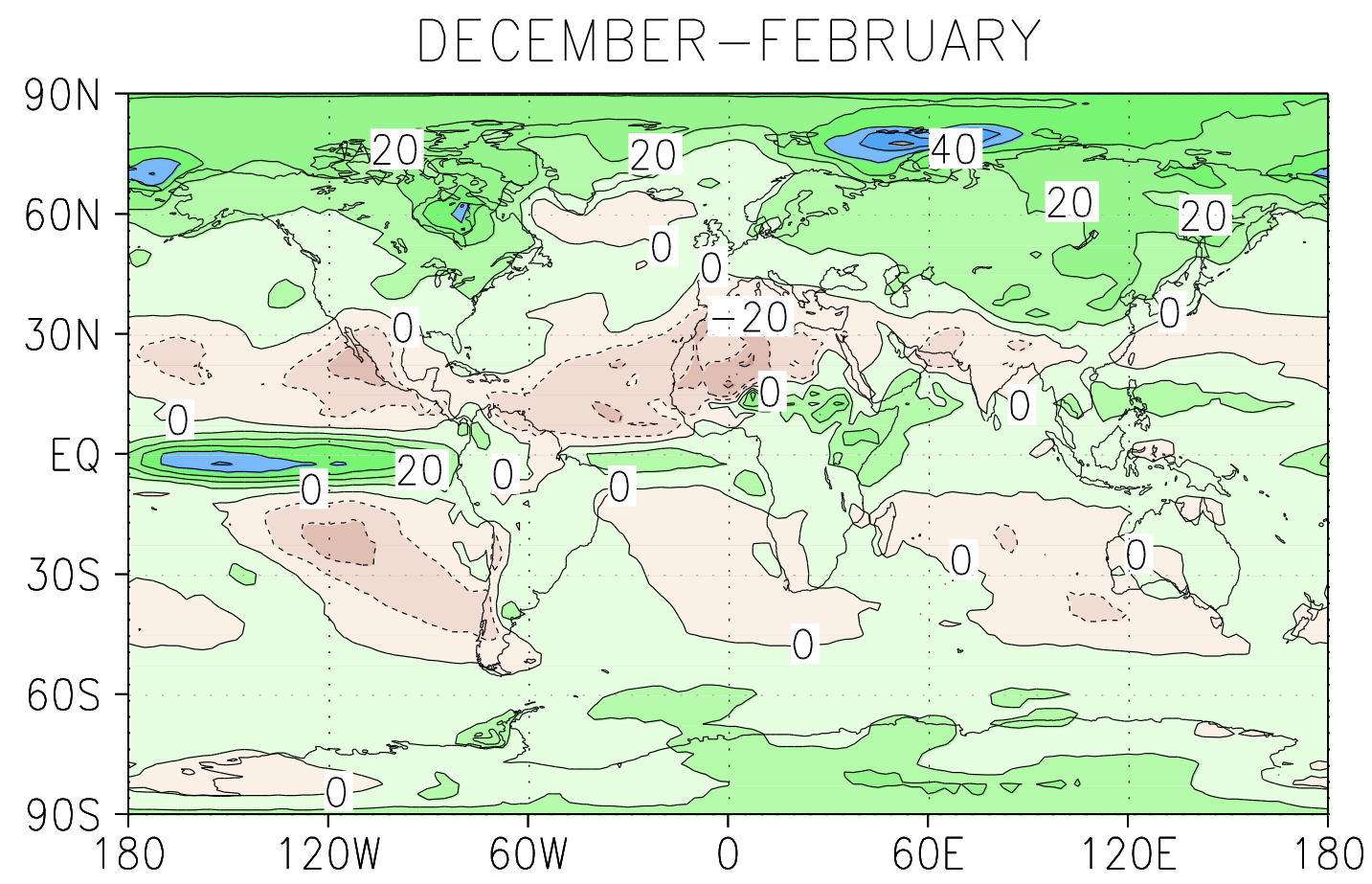

JUNE-AUGUST

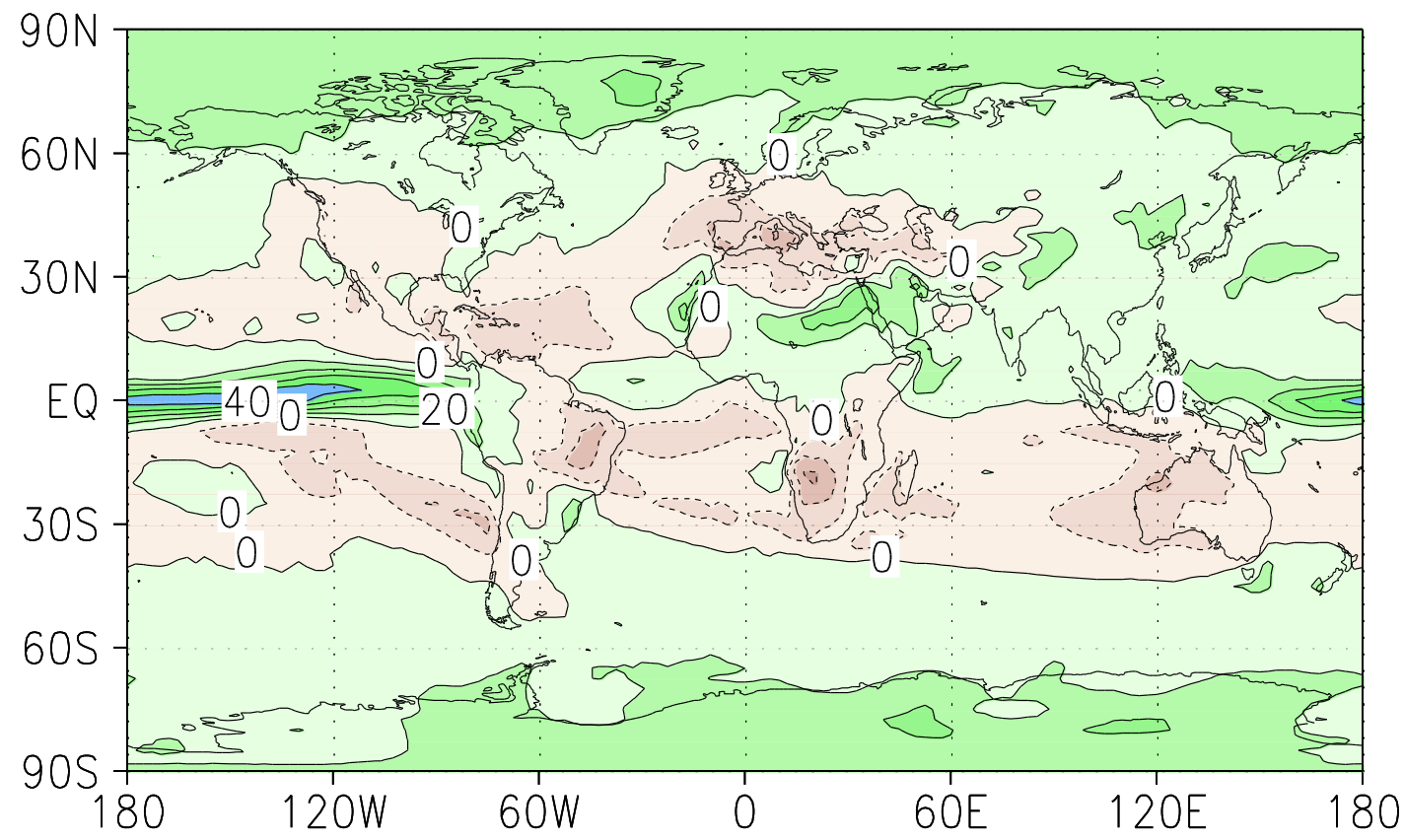

Figure 1.4: Projected multi-model mean change in precipitation (in \%) in DecemberFebruary (upper panel) and June-August (lower panel) from the period 1971-2000 to 2040-2069 under RCP4.5. 


\subsection{Climate change and forests}

Forest growth conditions are influenced by several climatological factors, e.g, air temperature, solar radiation and rainfall. In addition, the atmospheric concentration of $\mathrm{CO}_{2}$ has a major impact on forest productivity and forest dynamics. Increasing $\mathrm{CO}_{2}$ behaves as a fertilizer accelerating growth. Forests can remove large amounts of carbon from the atmosphere, but as well, large amounts of carbon can be released into atmosphere, e.g., during wide forest fires. There are also feedback mechanisms i.e., vegetation and forests impact meteorological phenomena like the absorption and reflection of solar radiation. Hence, change of forests to shrubs or grassland, or the opposite, may have substantial influence on earth's energy balance. Forests also act as a source of cloud-forming aerosols.

\subsection{Observed changes in forest resources}

Satellite measurements indicate greening of the world during the past decades. The greening based on the leaf area index $(\mathrm{LAI})^{3}$ is very prominent in India and China (Chen et al., 2019). In China, $42 \%$ of the greening is explained by forests and $32 \%$ by croplands whereas in in India, forests have a smaller contribution. Chen et al. (2019) estimated that for the EU, 51.4\% of vegetated land showed greening. According to Munier et al. (2018), satellite measurement indicate that LAI of the European forests has been increasing during the period 1995-2015 (Figure 1.5). The increase is most prominent in northern Europe. Both Munier et al (2018) and Chen et al. (2019) reported small changes of LAI for Uruguay. Elsewhere in South-America, like in southern Brazil, an increase of LAI has been detected whereas in the northern Brazil LAI has decreased.

The forested area has been declining for example in Brazil, Democratic Republic of Congo and Indonesia, and increasing e.g. in China (FAO, 2016). According to the FAO (2016) estimate, the global rate of forest loss will probably continue to decelerate in coming years and gradually level out. The fulfilment of FAO's prediction depends largely on political decisions taken by the major contributors like Brazil.

Forests cover about $33 \%$ of Europe and about $73 \%$ of the Finnish land area. The forest area in Europe (excluding the Russian Federation) is about 215 million hectares, and about 160 million hectares are available for wood supply. During the period 1990-2015, the forest area in Europe expanded by 17.5 million ha (Figure 1.6). Finland has the most extensive forest cover in Europe as 22.2 million hectares are classified as forest area.

\footnotetext{
${ }^{3}$ Leaf area index is defined as the projected area of leaves over a unit area of land surface $\left(\mathrm{m}^{2}\right.$ $\mathrm{m}^{-2}$ )
} 

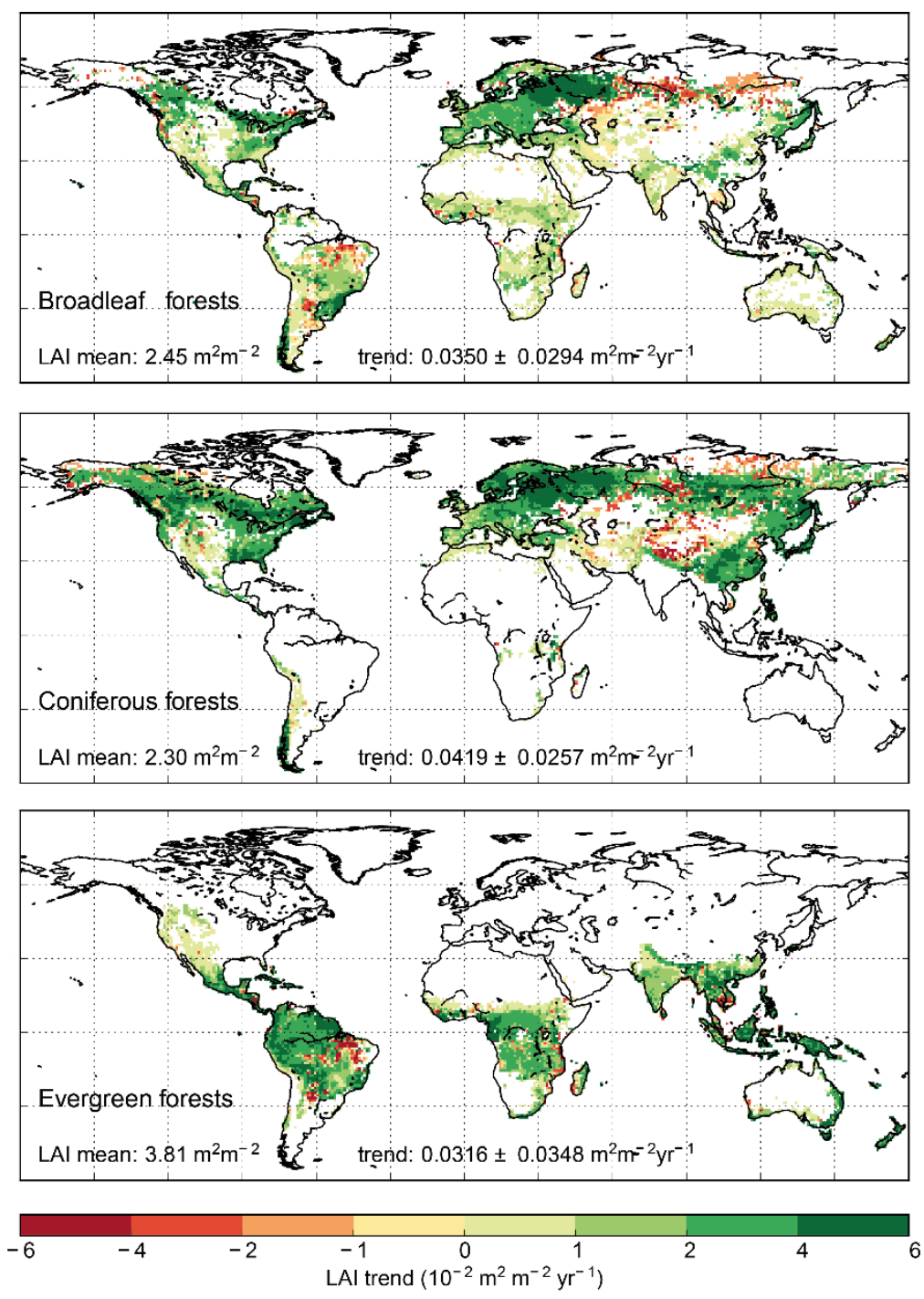

Figure 1.5: The trend of Leaf Area Index for broadleaf, coniferous and evergreen forests over the 1999-2015 period (Munier et al., 2018). Only areas with significant trend ( $p$ value <0.01) are marked by colour.

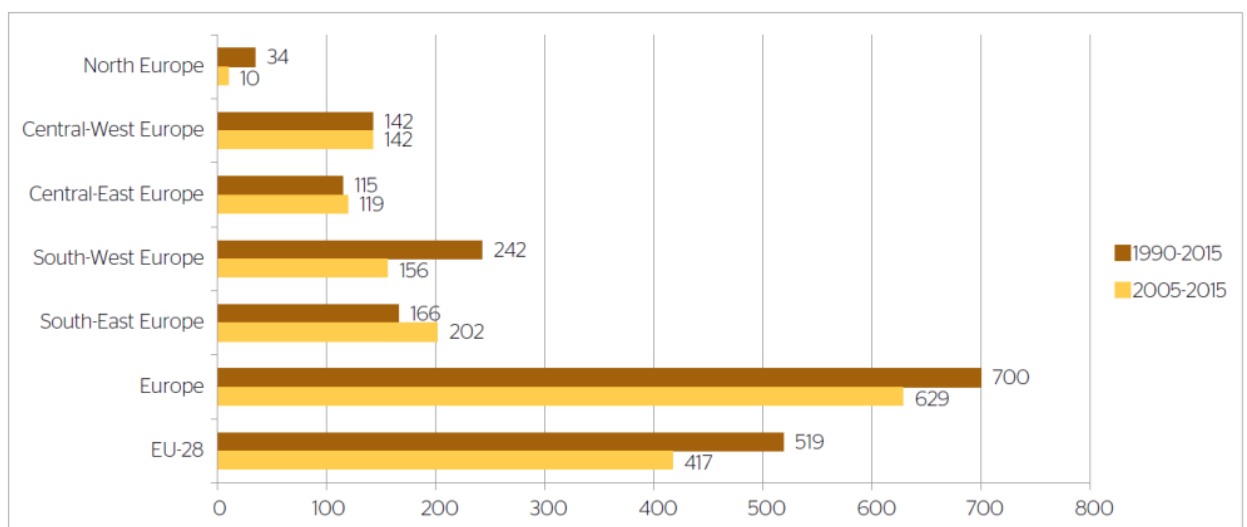

Figure 1.6: Annual increase in forest area by region in Europe, 1990-2015 and 20052015 (1,000 ha per year) (Forest Europe, 2015).

In Europe, about $66 \%$ of the annual forest increment is harvested, while in Finland that proportion is about $70 \%$ (LUKE, 2018; Forest Europe, 2015). The growing stock available for wood supply in Europe (excluding Russian Federation) is more than 29 milliard $\mathrm{m}^{3}$ and the annual increase about 400 million $\mathrm{m}^{3}$ (Forest Europe, 2015) (Figure 
1.7). In Finland, the annual increment of growing stock has been clearly larger than drain since the 1970s. In 2017, the estimated increment was 107 million $\mathrm{m}^{3}$ whereas the drain was 87 million $\mathrm{m}^{3}$ (Figure 1.8).

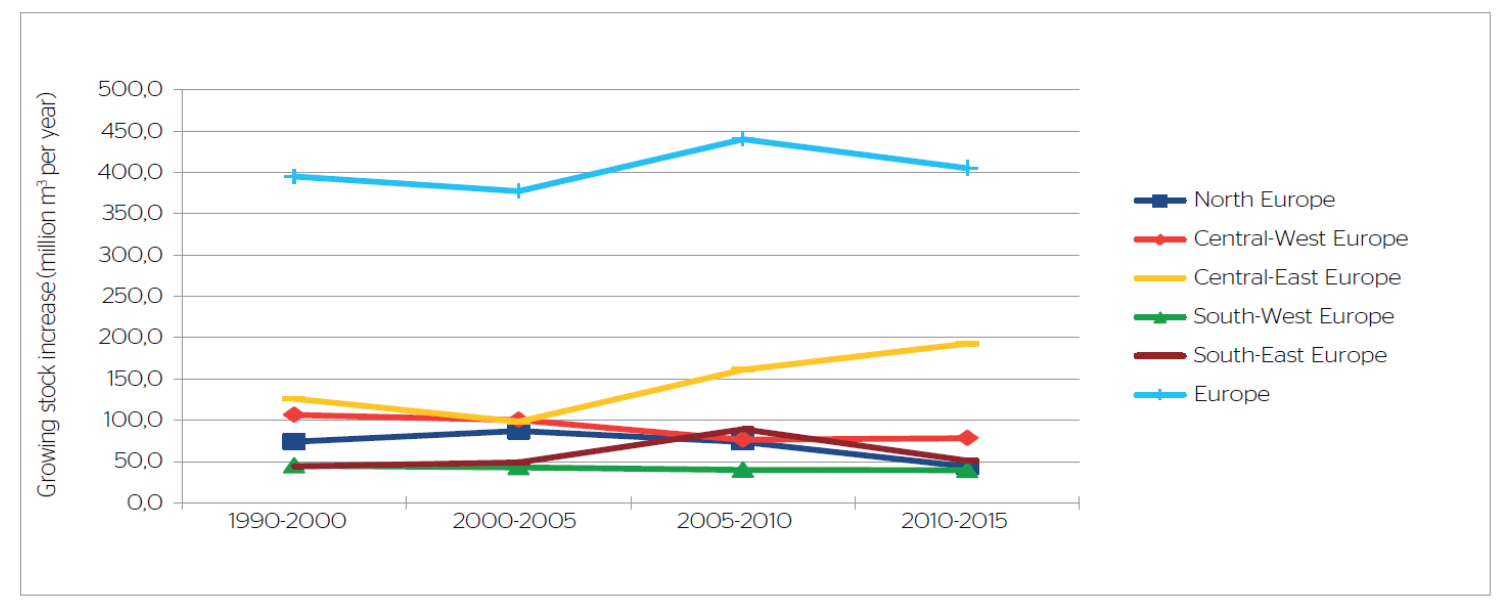

Figure 1.7: Annual increase in growing stock (million $\mathrm{m}^{3}$ per year) by region, 1990-2015 (Forest Europe, 2015).

The distribution of tree species is changing significantly but slowly. Trees migrate relatively slowly, primarily into newly suitable habitats, e.g., towards the north and higher altitudes. Simultaneously, former suitable habitats may become unsuitable, e.g., due to changed precipitation patterns leading to droughts. The climate change affects forest ecosystems and individual species. The assessment of the total impacts is not always straightforward as forests are under management, and the effects of forest management are difficult to separate from the influence of climate change. Nevertheless, over the past decades, forest biomass has increased at an accelerating rate (EEA, 2016a; EEA, 2016b).

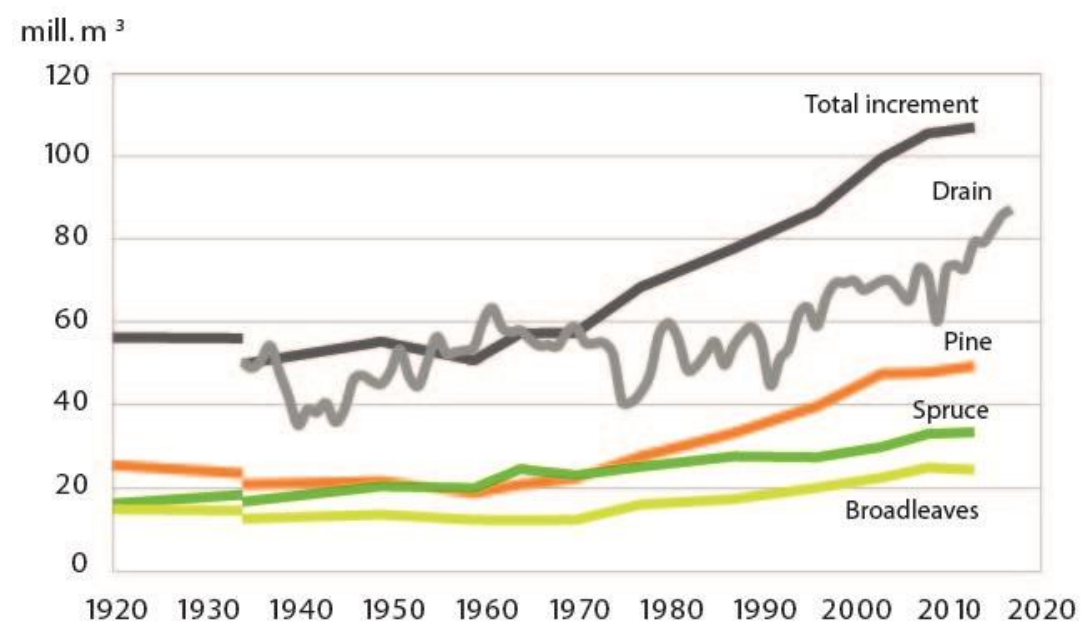

Figure 1.8: The annual growth and drain of trees (felling and death due to natural causes) in Finland (Lier et al., 2018).

\section{Climate change and its impacts in Europe}

\subsection{Overview of projected climate change in Europe}

When considering the multi-model mean and the mid-century climate under RCP4.5, climate models project the largest annual mean temperature increase, more than $3^{\circ} \mathrm{C}$, for 
the north-eastern parts of Europe (Figure 2.1(a)). In western Europe and on the coasts of the Mediterranean Sea, warming would correspondingly be about $2^{\circ} \mathrm{C}$ or even less. Annual precipitation is projected to increase in northern and central Europe and to decrease in the south, the largest local changes being about $\pm 10 \%$ (Figure $2.1(\mathrm{~b})$ ).

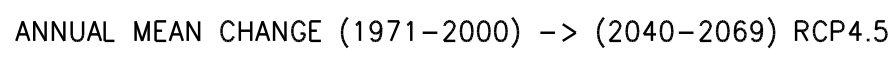

(A) TEMPERATURE

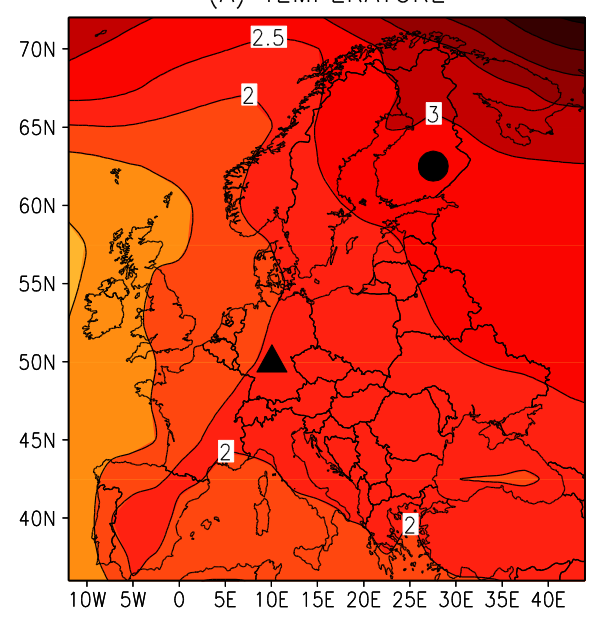

(C) SOLAR RADIATION

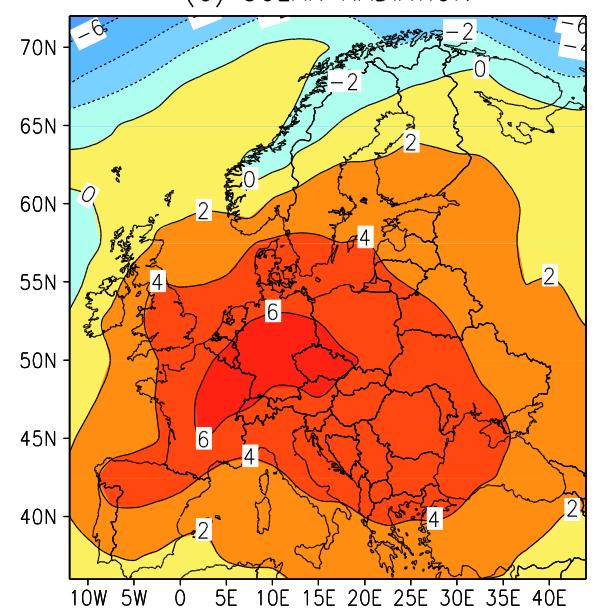

(B) PRECIPITATION

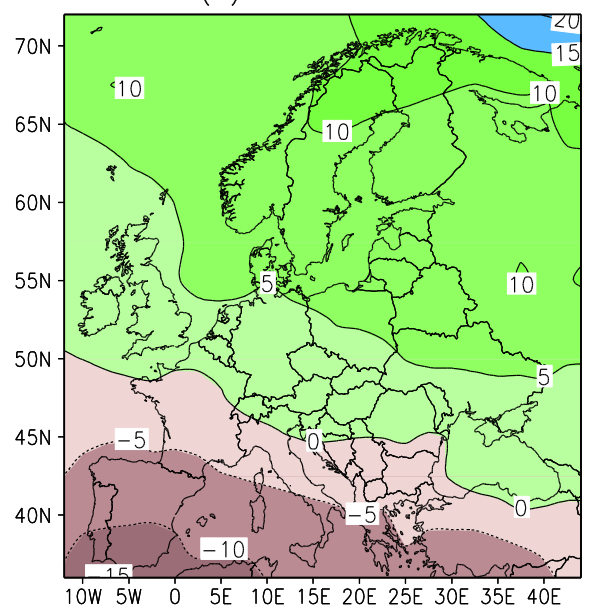

(D) RELATIVE HUMIDITY

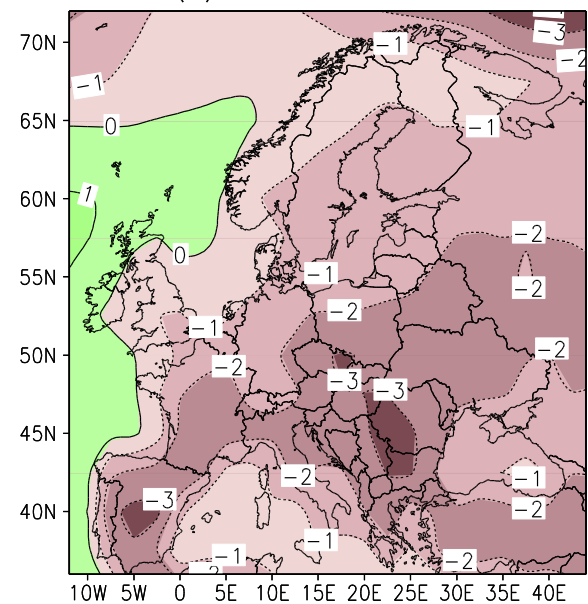

Figure 2.1: Projected changes in annual mean (a) temperature $\left(\right.$ in $\left.{ }^{\circ} \mathrm{C}\right),(\mathrm{b})$ precipitation (in \%), (c) incident solar radiation (in \%) and (d) relative humidity (in percentage points) in Europe from the period 1971-2000 to 2040-2069 under RCP4.5. The positions of the grid point $62.5^{\circ} \mathrm{N}, 27.5^{\circ} \mathrm{E}$ and $50^{\circ} \mathrm{N}, 10^{\circ} \mathrm{E}$, examined in the more detailed analyses, are marked by a dot and a triangle in panel $(a)$.

The annual aggregate amount of solar radiation received at the surface appears to increase in the majority of the continent, in central Europe by up to about $6 \%$ (Figure 2.1(c)). Changes in relative humidity (RH) are fairly modest. In the bulk of Europe, RH decreases by 1-3 percentage point (Figure 2.1(d)); most strongly in southern European inland areas. In conjunction with changes in the mean climate, temporal variations of temperature will attenuate and fluctuations in precipitation amplify, mainly in northern and north-eastern Europe (Figure 2.2). As will be shown below, in reality all these changes are subject to substantial seasonal variability and inter-model differences. 
ANNUAL MEAN CHANGE (1971-2000) -> (2040-2069) RCP4.5

(A) TEMPERATURE STDEV

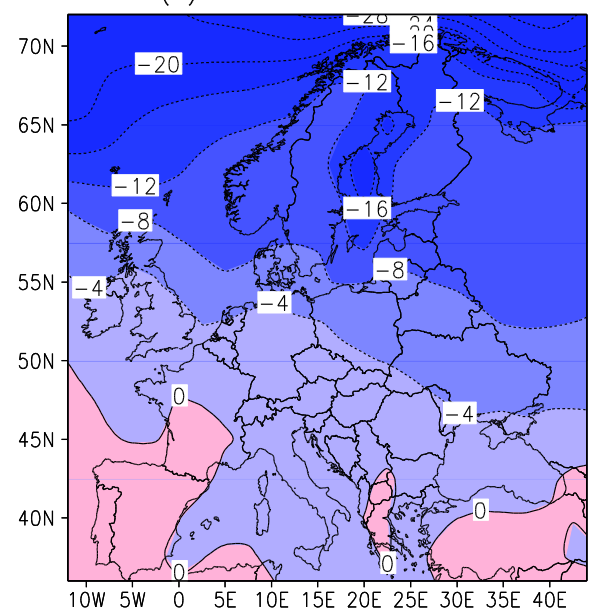

(B) PRECIPITATION STDEV

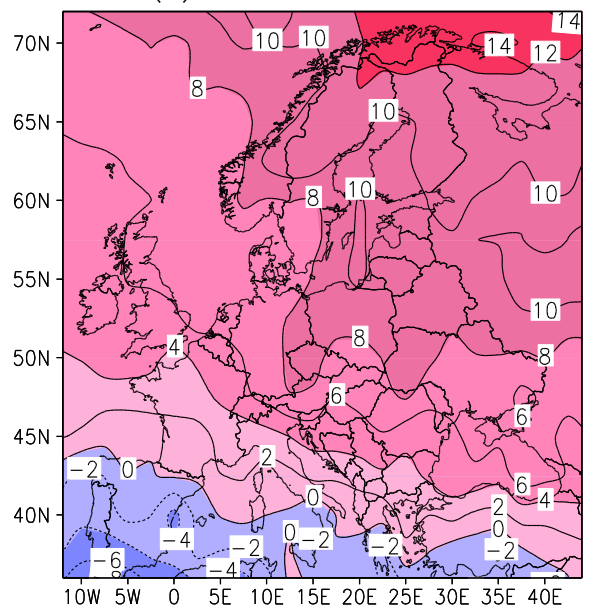

Figure 2.2: Projected changes in the standard deviation of temporal variations in (a) temperature and (b) precipitation (both in \%) in Europe from the period 1971-2000 to 2040-2069 under RCP4.5.

In contrast to temperature, precipitation and many other climate quantities, changes in the wind speeds do not appear to be particularly significant. By the mid-century, time mean wind speeds generally alter less than $\pm 2 \%$ (Figure 2.3 ). The somewhat larger changes apparent in southern European mountainous areas in summer are evidently spurious, induced by the subterranean extrapolation of surface pressure into the standard sea level (Ruosteenoja et al., 2019). 
(A) DEC-FEB RCP 4.5

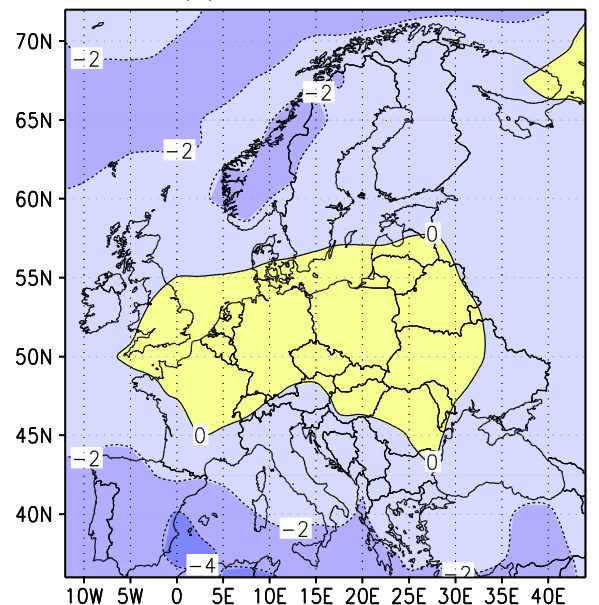

(B) MAR-MAY RCP 4.5

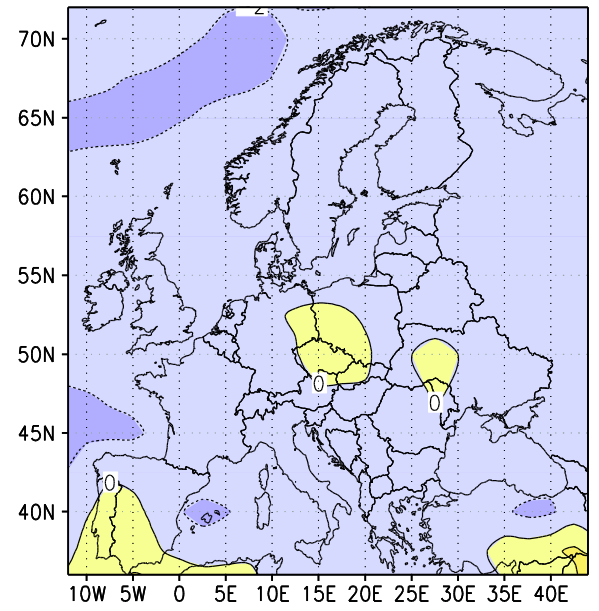

(C) JUN-AUG RCP4.5

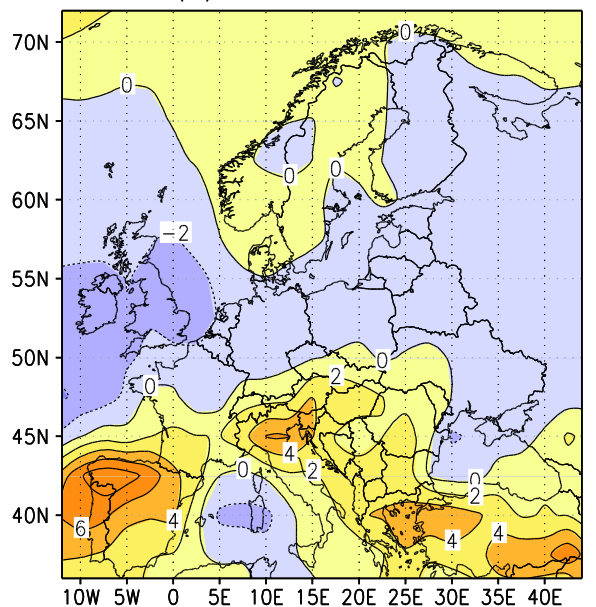

(D) SEP-NOV RCP4.5

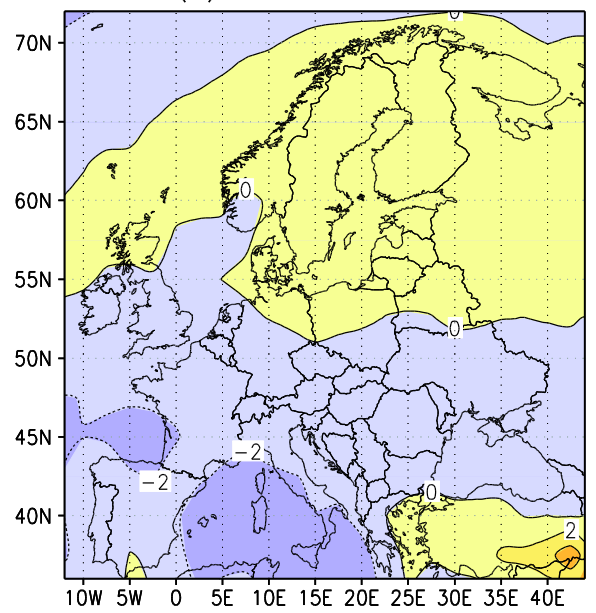

Figure 2.3: Projected seasonal changes (in percent) in the time-mean geostrophic wind speed from 1971-2000 to 2040-2069 in Europe under RCP4.5 in (a) December-February, (b) March-May, (c) June-August and (d) September-November. The contour interval is 2 $\%$.

\subsubsection{Finland}

Multi-model mean projections for the temporal evolution of four key climate quantities in Finland are shown in Figure 2.4. The grid point considered, $62.5^{\circ} \mathrm{N}, 27.5^{\circ} \mathrm{E}$, is located in eastern central Finland (the position of the point is marked in Figure 2.1(a)) and thus represents the area of the most intensive forestry in Finland.

Annual mean temperature in Finland (Figure 2.4(a)) increases by 1.6-1.9 times as rapidly as the global mean temperature (see Figure 1.2). In a qualitative sense, however, the temporal evolution of the change is very similar. In the early 21 st century, temperature is projected to rise by $0.4-0.5^{\circ} \mathrm{C}$ per a decade. Near the mid-century and, in particular, the second half of the present century, the projected temperature increases corresponding to the three RCP scenarios tend to gradually diverge. According to RCP8.5, warming continues at nearly a constant rate. Under RCP4.5, warming likewise continues throughout the 21th century but is less rapid in the second than in the first half of the century. If the extremely low-emission RCP2.6 scenario were realized, warming would cease after the 2050s. Under the RCP8.5 scenario, annual mean temperature in Finland would increase by nearly $6^{\circ} \mathrm{C}$ in hundred years. Under RCP4.5, the corresponding warming would be 
about $3.6^{\circ} \mathrm{C}$ and under RCP2.6 only $2.2^{\circ} \mathrm{C}$. This demonstrates the potential of vigorous climate policy to reduce warming in the long run.

TIME SERIES OF CHANGE FOR CENTRAL FINLAND

(A) TEMPERATURE, $62.5^{\circ} \mathrm{N}, 27.5^{\circ} \mathrm{E}$

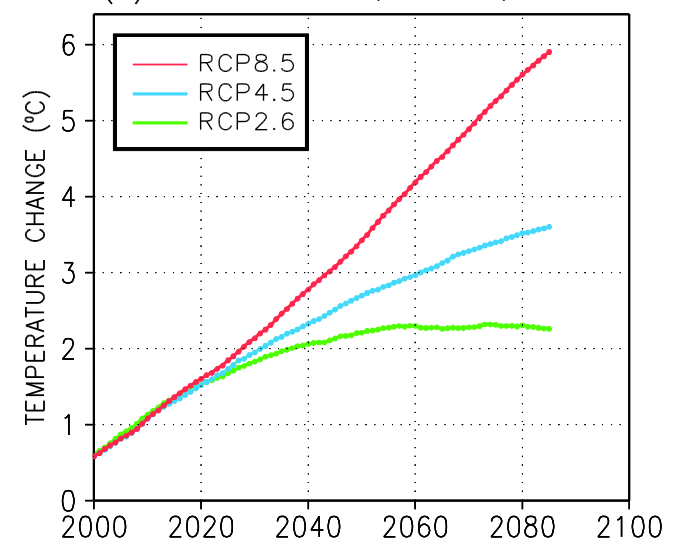

(C) SOLAR RADIATION, $62.5^{\circ} \mathrm{N}, 27.5^{\circ} \mathrm{E}$

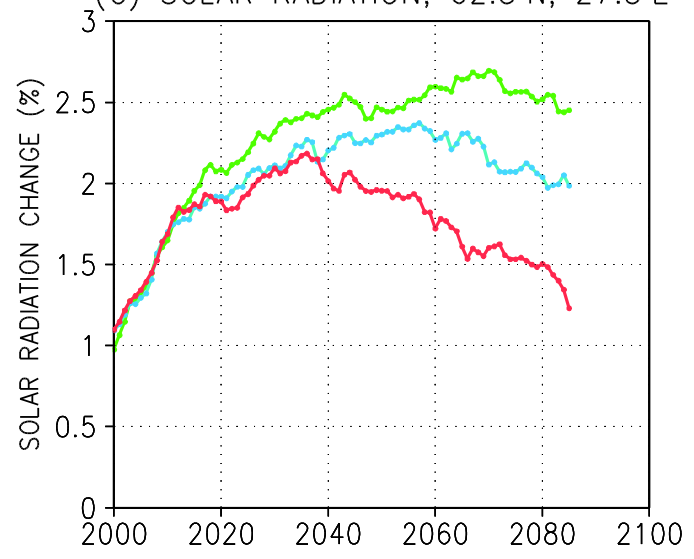

(B) PRECIPITATION, $62.5^{\circ} \mathrm{N}, 27.5^{\circ} \mathrm{E}$

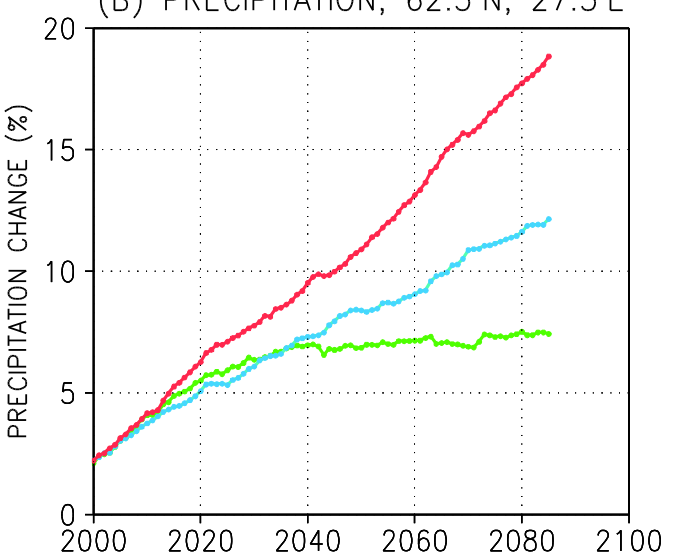

(D) RELATIVE HUMIDITY, $62.5^{\circ} \mathrm{N}, 27.5^{\circ} \mathrm{E}$

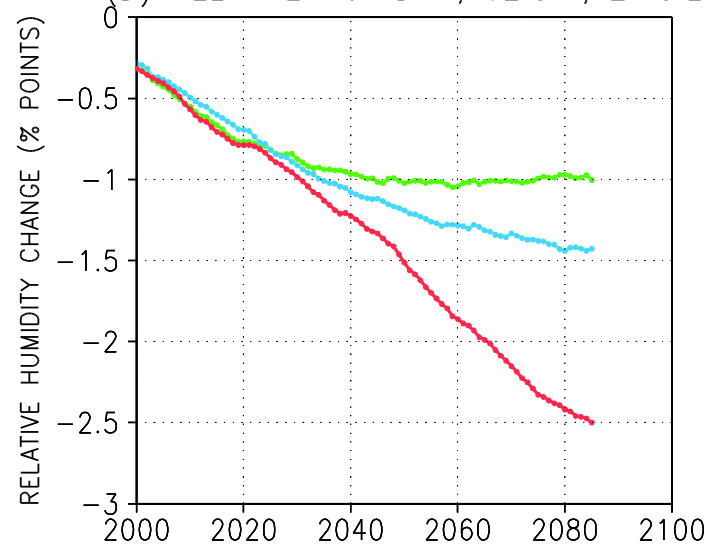

Figure 2.4: Projected annual mean changes relative to 1971-2000 in (a) mean temperature (in $\left.{ }^{\circ} \mathrm{C}\right),(b)$ precipitation (in \%), (c) incident solar radiation (in \%) and (d) relative humidity (in percentage points) at $62.5^{\circ} \mathrm{N}, 27.5^{\circ} \mathrm{E}$ (central Finland; the position is marked in Figure 2.1(a)). The time series are shown separately for the RCP2.6, RCP4.5 and RCP8.5 scenarios (see the legend).

When considering all three RCP scenarios but not inter-model scatter, annual precipitation total is projected to increase by $7-18 \%$ by the late- 21 st century (Figure 2.4(b)). In this case as well, the business-as-usual RCP8.5 scenario yields the largest change. In incident solar radiation and relative humidity, changes are fairly small on the annual-mean level (Figures 2.4(c-d)). The quite rapid increase in the simulated solar solar radiation prior to the 2020s is partially explained by the decreasing emissions of sulphur dioxide and other pollutants acting as aerosol precursors in Europe after the 1980s. 
(A) TEMPERATURE, $62.5^{\circ} \mathrm{N}, 27.5^{\circ} \mathrm{E}$

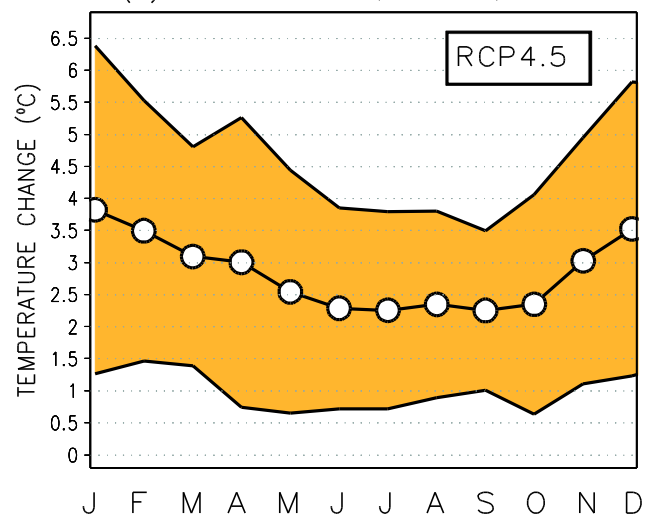

(C) SOLAR RADIATION, $62.5^{\circ} \mathrm{N}, 27.5^{\circ} \mathrm{E}$

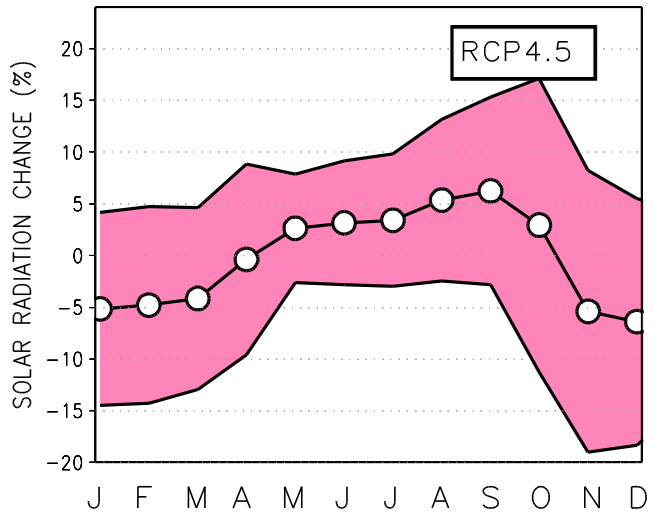

(E) TEMPERATURE STDEV, $62.5^{\circ} \mathrm{N}, 27.5^{\circ} \mathrm{E}$

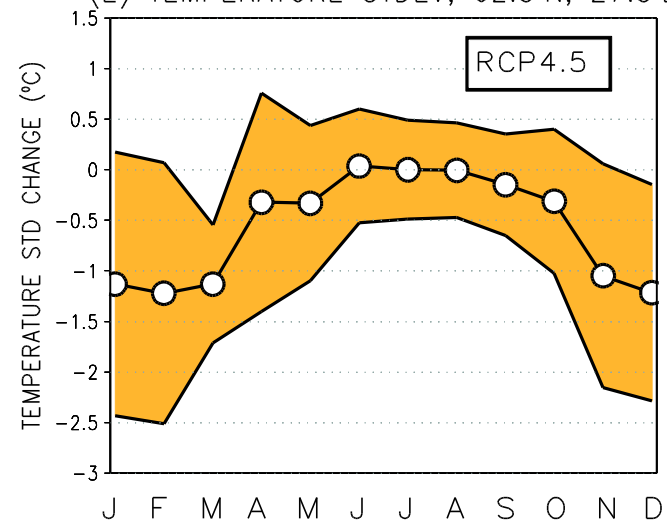

(B) PRECIPITATION, $62.5^{\circ} \mathrm{N}, 27.5^{\circ} \mathrm{E}$
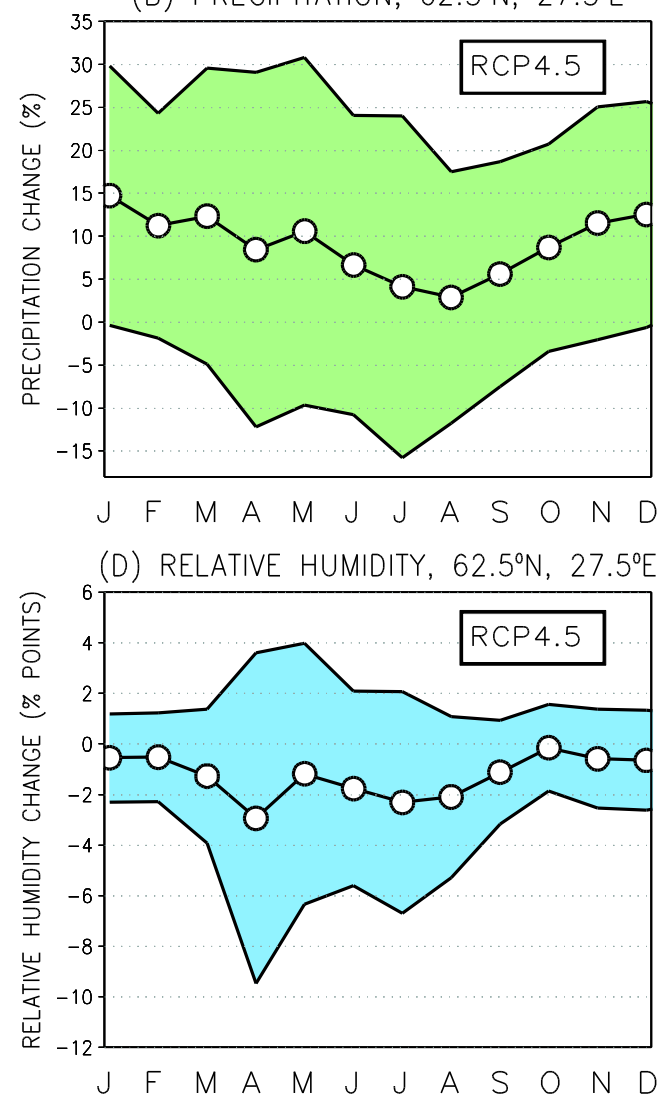

(F) PRECIPITATION STDEV, $62.5^{\circ} \mathrm{N}, 27.5^{\circ} \mathrm{E}$

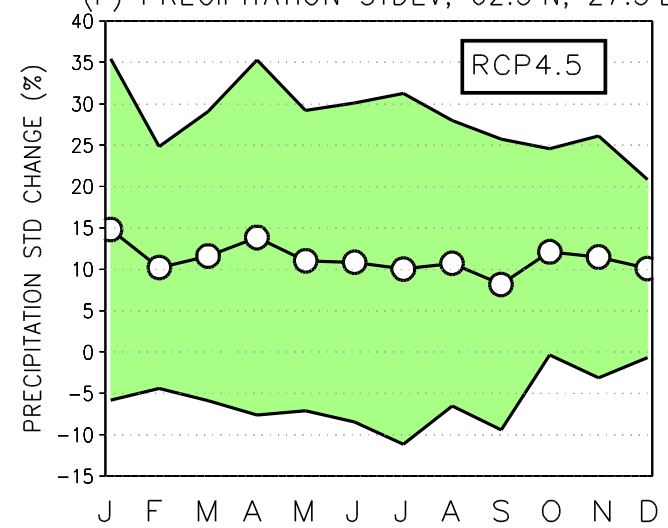

Figure 2.5: Projected monthly changes in (a) the mean temperature (in $\left.{ }^{\circ} \mathrm{C}\right),(b)$ precipitation (in \%), (c) incident solar radiation (in \%) and $(d)$ relative humidity (in percentage points) at $62.5^{\circ} \mathrm{N}, 27.5^{\circ} \mathrm{E}$ (central Finland; the position is marked in Figure 2.1(a)) under RCP4.5 for the period 2040-2069, relative to 1971-2000. Corresponding changes in the temporal standard deviation of daily-mean temperature $\left(\right.$ in ${ }^{\circ} \mathrm{C}$ ) and precipitation (in \%) are shown in panels (e) and (f). The multi-model mean projections for individual calendar months $(J=$ January,..., $D=$ December $)$ are denoted by open circles. Shading shows the $90 \%$ uncertainty intervals for the projection.

The seasonal course of projected changes in multiple climate indicators, along with an estimate of the inter-model scatter in the change, is depicted in Figure 2.5. Increases in temperature are simulated by all the models, the warming being larger in winter than in summer. According to the multi-model mean, temperature would increase (by the mid- 
century) by about $4{ }^{\circ} \mathrm{C}$ in mid-winter and slightly more than $2^{\circ} \mathrm{C}$ in summer and early autumn. Even so, inter-model differences in the simulated temperature change are substantial. For winter temperatures, the $90 \%$ probability interval of the increase ranges from about $1^{\circ} \mathrm{C}$ to $5-6^{\circ} \mathrm{C}$. The corresponding uncertainty interval for the projected summertime warming is from 1 to $4^{\circ} \mathrm{C}$. Note, however, that according to the normality assumption it is more likely that future warming will fall near the multi-model mean estimate than close to the edges of the interval.

For precipitation, the most likely projection is an increase of $15 \%$ in winter and of $\sim 5$ $\%$ in summer (Figure 2.5(b)). In winter, inter-model agreement on the increasing future precipitation is high but the uncertainty interval is nevertheless wide, ranging from nearly 0 to $30 \%$. In other seasons, particularly in summer, there is a nonnegligible likelihood that precipitation would even decrease; in July, for instance, the uncertainly interval ranges from $-15 \%$ to $+25 \%$. Solar radiation is likely to diminish from November to March and increase in summer and early autumn, even though the inter-model scatter is large (Figure 2.5(c)). The signal-to-noise ratio is likewise low for relative humidity projections; the most likely alternative is that $\mathrm{RH}$ would decrease by about $2 \%$ in spring and summer and remain virtually unchanged in autumn and winter (Figure $2.5(\mathrm{~d})$ ).

Climate change affects moisture conditions in the soil as well. Figure 2.6 shows the seasonal cycle of the near-surface soil moisture change for central Finland. A very significant drying is apparent in spring; this is related to an earlier melting of snow and soil frost in the future. In the summer months, the decline of soil moisture is fairly modest. The response in soil moisture is a residual of the influences of increasing precipitation and the strengthening evaporation induced by higher temperatures.

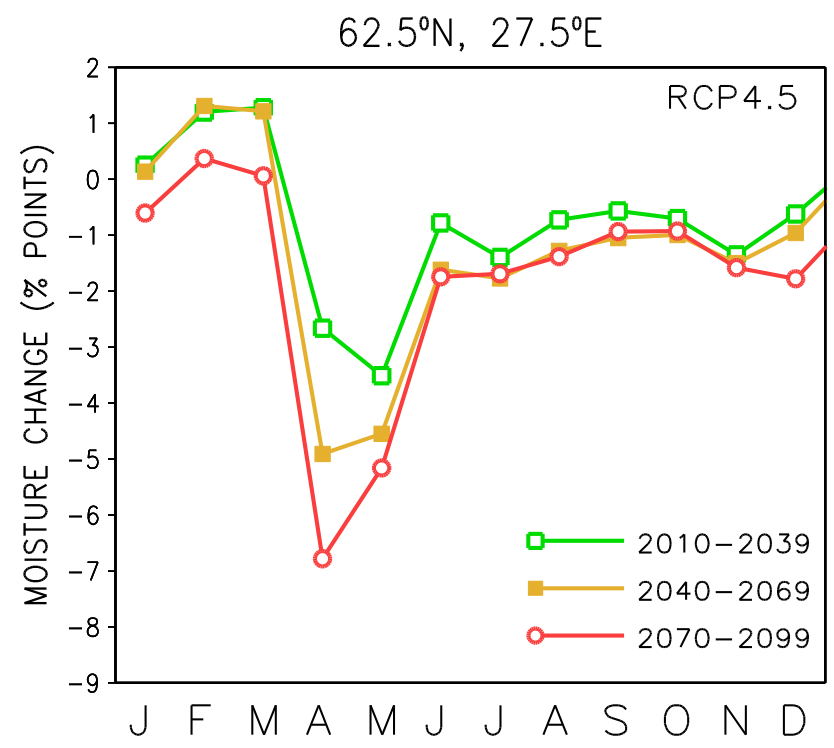

Figure 2.6: Multi-model mean monthly responses $(J=$ January, $F=$ February, ... $)$ in nearsurface (the uppermost $10 \mathrm{~cm}$ layer) soil moisture (in percentage points) for three future time spans (2010-2039, 2040-2069 and 2070-2099, relative to 1971-2000; see the legend) at $62.5^{\circ} \mathrm{N}, 27.5^{\circ} \mathrm{E}$ under the $R C P 4.5$ scenario.

The temporal fluctuations of temperature will attenuate in winter (Figure 2.5(e)). This indicates that the most extreme low wintertime temperatures will become much warmer. In the mean temperature and particularly in the mildest temperatures, warming is not as large. Accordingly, in the future the Finnish wintertime temperature climate is going to be less variable than in the recent past. In summer, no drastic changes in the variability are to 
be anticipated; relatively cold and warm temperatures become warmer broadly at an equal rate.

In precipitation, temporal variations are likely to intensify (Figure 2.5(f)). Considering the multi-model mean, in winter the increase in the variability is of the similar magnitude as the increase in the time-mean precipitation, in summer somewhat larger. Although the $90 \%$ probability interval of the change intersects the zero line, an increase in the variability is far more likely than a decrease.

Simultaneous increases in the mean precipitation and its variability imply that heavy precipitation events will intensify. This tendency is even more distinctly apparent (in part, due to the more distant projection period) in Figure 2.7, which shows the long-term averaged change in the 24-hour precipitation total of the wettest day of the season. According to the multi-model median, the maximum 1-day precipitation would increase by $12-17 \%$, depending on the season. Inter-model scatter is certainly fairly large in this quantity as well, but virtually all the models examined simulate at least some increase in extreme precipitation. In summer, for instance, the interquartile interval of the increase in this precipitation index is from 11 to $23 \%$, in winter from 10 to $15 \%$. Some individual models project even far more intense increases.

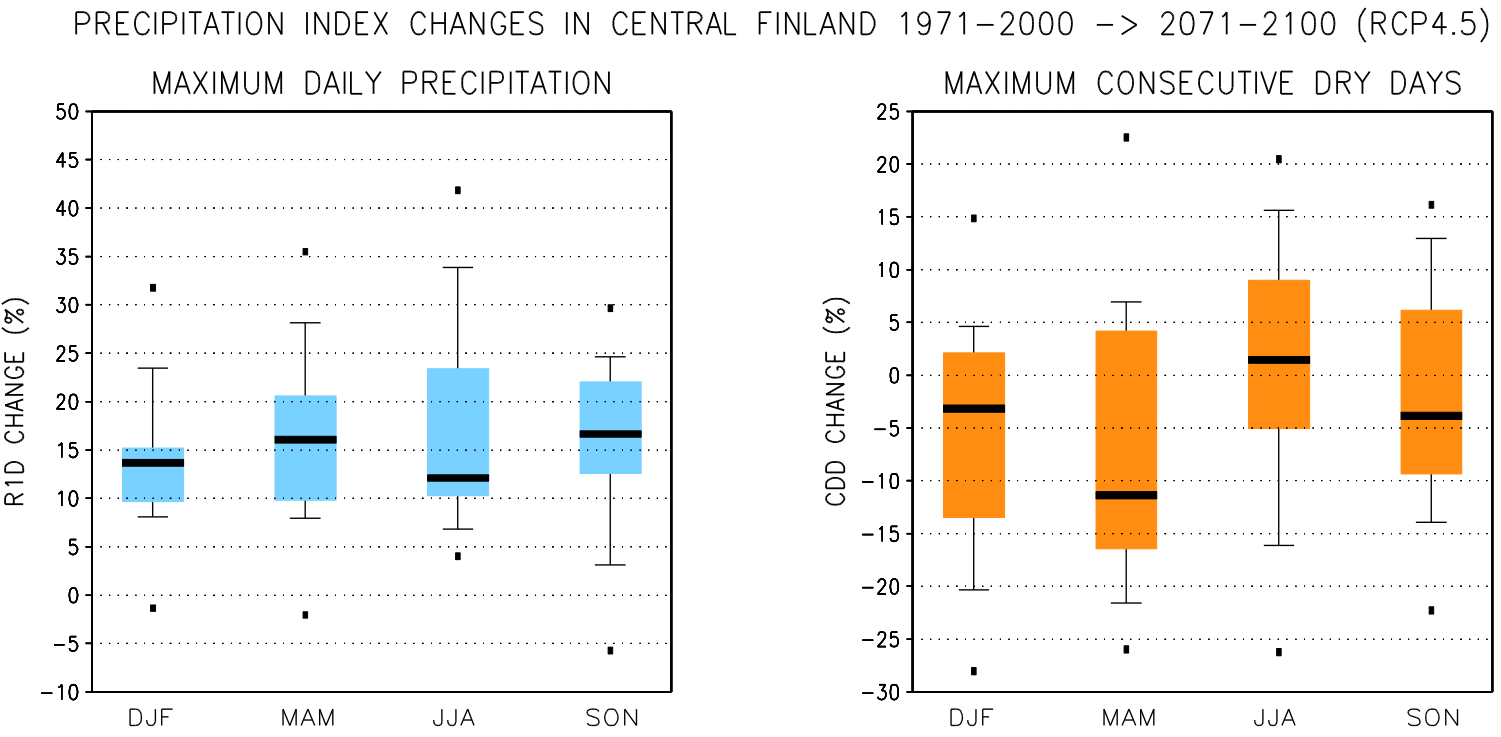

Figure 2.7: Model-derived seasonal changes (in percent) in the maximum one-day precipitation RId (left panel) and the maximum number of consecutive dry days CDD (with precipitation < $1 \mathrm{~mm} /$ day; right panel) at $62.5^{\circ} \mathrm{N}, 27.5^{\circ} \mathrm{E}$ (central Finland; the position is marked in Figure 2.1(a)) under RCP4.5 for the period 2071-2100, relative to 1971-2000. The coloured bars show the 25th to 75th percentile intervals of the change derived from the responses of 21 models. The corresponding 10th to 90th percentile intervals are depicted by whiskers and the minimum and maximum responses among the models by black dots. The black lines within the bars stand for the multi-model medians. The probability distributions are given separately for four seasons: December-February (DJF), March-May (MAM), June-August (JJA) and September-November (SON).

The wetter future climate in Finland also manifests itself in changes in the number of consecutive dry days (Figure 2.7). A majority of the models simulate a shortening of dry periods in all seasons except summer, even though in this index inter-model agreement is not as high as in the above-discussed heavy-precipitation index. In summer, the number of models simulating shorter and longer dry periods in the future is virtually equal. 
The persistently continuing warming results in warmer and longer growing seasons. The thermal growing season (i.e., the period with daily mean temperatures above $5^{\circ} \mathrm{C}$; see the appendix) appears to lengthen by 10-15 days both in spring and autumn (from 19712000 to 2040-2069 under RCP4.5; Figure 2.8).
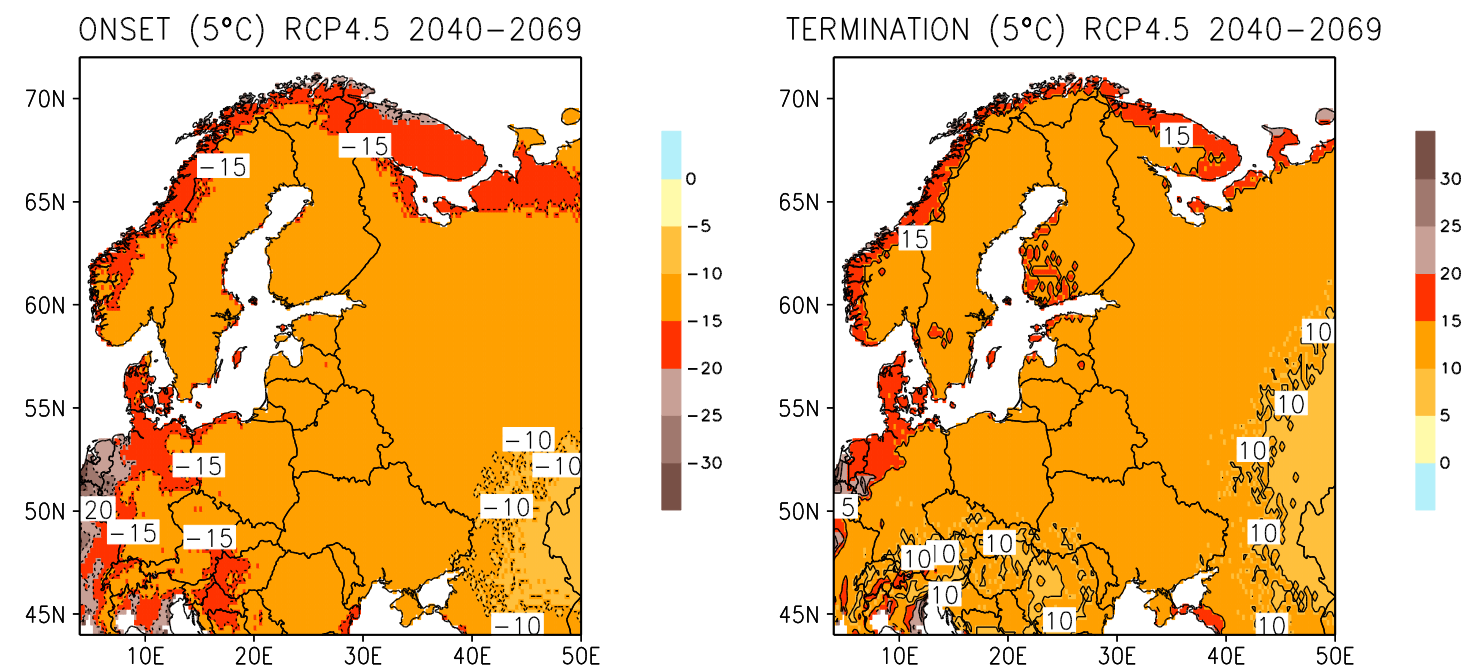

Figure 2.8: Projected multimodel-mean changes in the onset (left) and termination dates (right) of the thermal growing season for the period 2040-2069 under RCP4.5, relative to 1971-2000. Base temperature is $5^{\circ} \mathrm{C}$ (re-drawn from Ruosteenoja et al., 2016b).
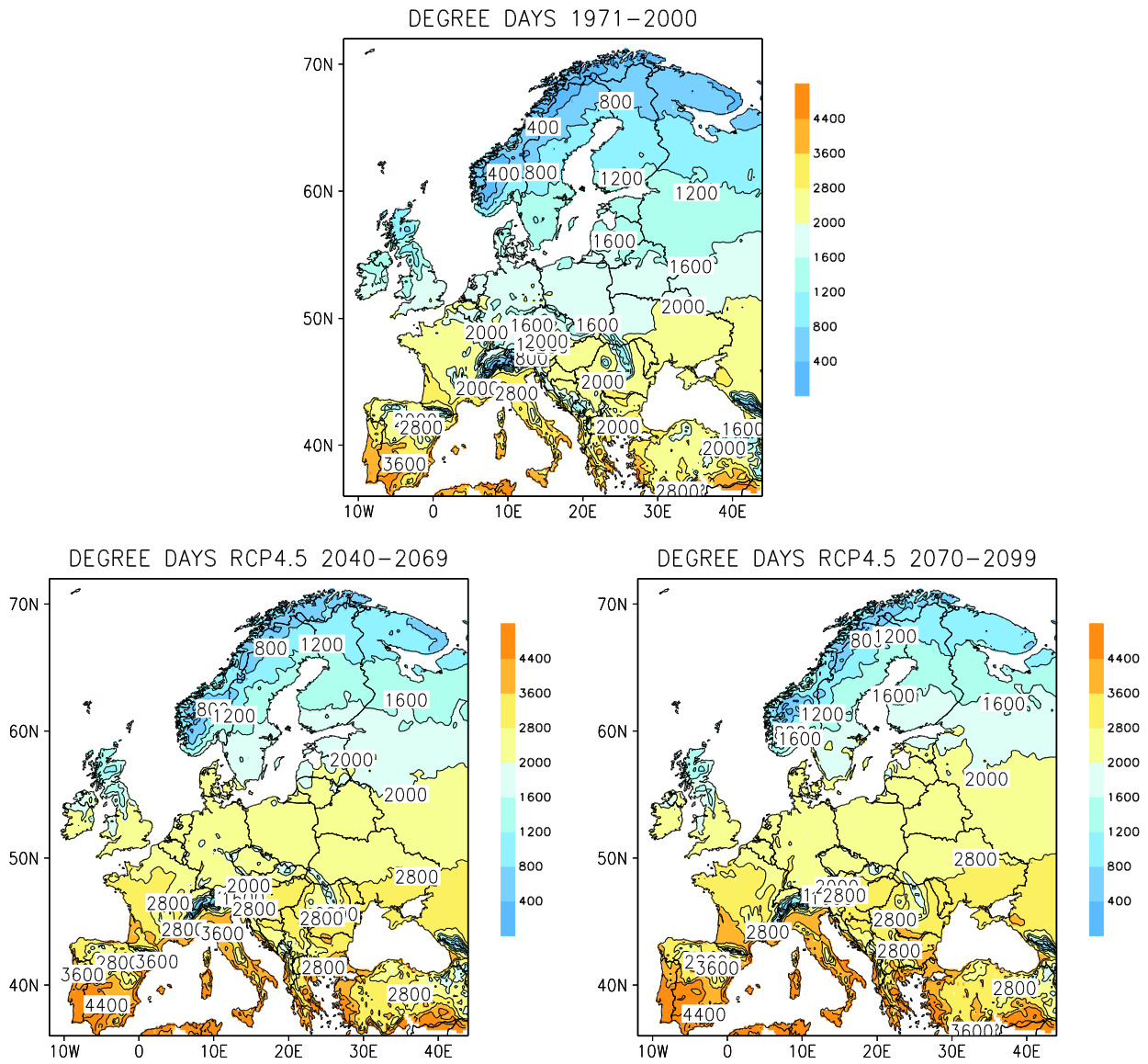

Figure 2.9: Baseline values (years 1971-2000; at the top) and future projections (periods 2040-2069 and 2070-2099; bottom) for the temperature sum of the growing season under RCP4.5. Base temperature is $5^{\circ} \mathrm{C}$ (re-drawn from Ruosteenoja et al., 2016b). 
Concurrently, the temperature sum of the growing season increases by several hundreds of degree days. In the mid-century, the average growing degree day sum in southern Finland would be approximately as large as it was in Poland or East Germany in the late-20th century (Figure 2.9). By the end of the 21 st century, temperature sums would further increase to some extent.

As it was shown in Figure 2.3, temporally averaged wind speeds are not expected to change substantially. According to Figure 2.10, the same conclusion holds for strong winds (note that in this case the projection is given for the RCP8.5 scenario). Strong wind speeds, corresponding to the 99th percentile of the frequency distribution, may increase by $0-2 \%$ in summer and autumn, and in the other two seasons the projected change is even more negligible. Moreover, the proportion of westerly winds is anticipated to increase slightly at the cost of easterly winds.
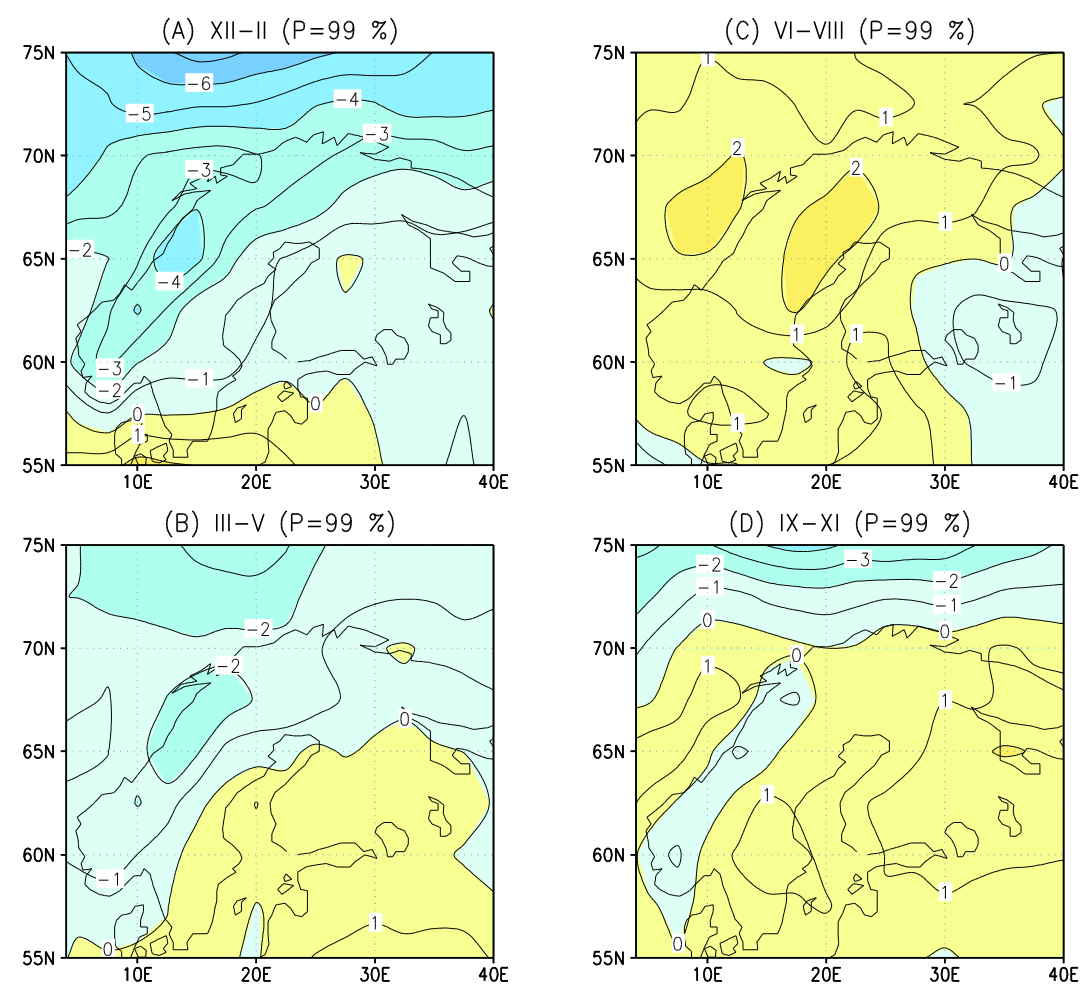

Figure 2.10: Projected changes in strong geostrophic wind speeds (in percent) in Northern Europe from the period 1961-2005 to 2040-2069 under RCP8.5: (a) winter, (b) spring, (c) summer and $(d)$ autumn. The changes are shown for the geostrophic wind speed corresponding to the 99 th percentile of the frequency distribution.

Climate change also influences hydrological conditions. As an example of this, the simulated monthly discharge of the Kymmene river in south-eastern Finland is depicted in Figure 2.11. In the climate that prevailed in the turn of the millennium (note that the baseline period is here 1981-2010 rather than 1971-2000), the time-mean discharge was nearly uniform throughout the year.

In the future, winters become milder and wetter, and consequently an increasing proportion of the larger precipitation is received in the form of rain rather than snow. This makes the wintertime discharges to increase. Owing to the shallower winter snow cover, springtime floods gradually weaken and ultimately disappear. In summer, precipitation increases slightly but in the warmer climate evaporation of water intensifies as well; this reduces water resources, and summertime discharges decrease accordingly. Considering the period 2040-2069, mid-winter discharges are projected to increase by more than $30 \%$ and late-summer discharges to decrease by about $20 \%$. For further information about 
future hydrological conditions in selected Finnish watersheds, including extreme conditions and the impact of inter-model differences, the reader can consult the report of Veijalainen et al. (2018).
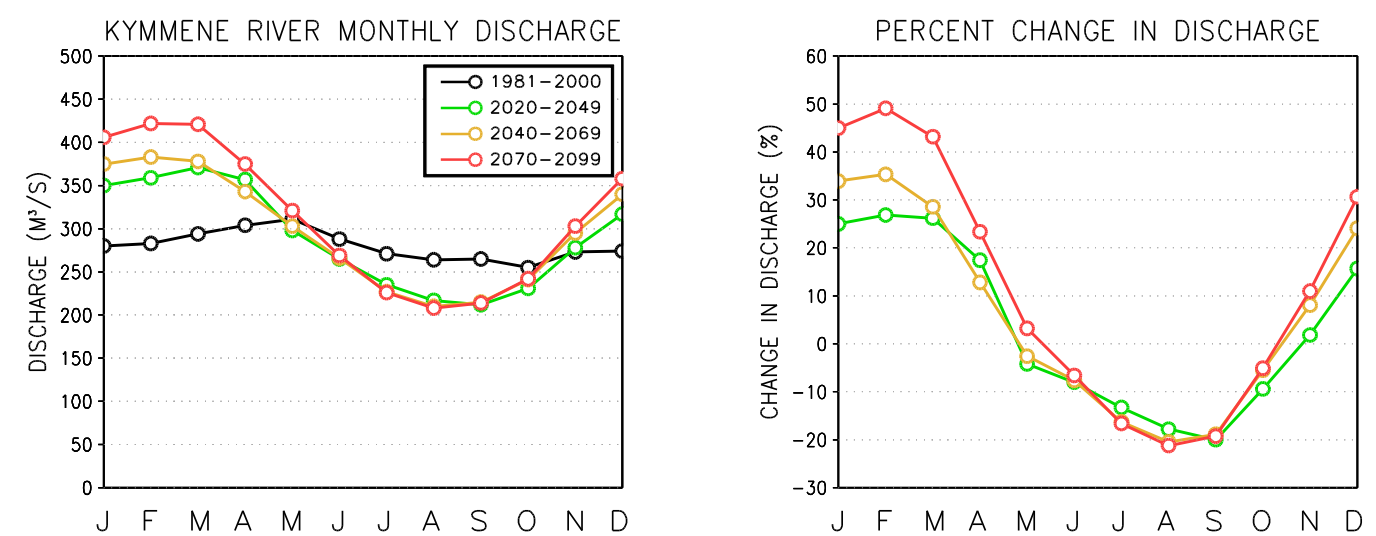

Figure 2.11: (a) Simulated temporally averaged monthly $(J=$ January,..., $D=$ December $)$ discharge (in $\left.\mathrm{m}^{3} \mathrm{~s}^{-1}\right)$ at Anjalankoski on the Kymmene river $\left(60.7^{\circ} \mathrm{N}, 26.8^{\circ} \mathrm{E}\right)$ under $R C P 4.5$ for the periods 1981-2010, 2020-2049, 2040-2069 and 2070-2099 (see the legend). (b) Projected changes for the three future periods. Re-drawn using the data given in Table L2 of Veijalainen et al. (2018).

In Finland, the projected climatic change hereby turns out to be strongest in winter: precipitation increases substantially, solar radiation declines to some extent and the temperature increase is stronger than in the other seasons. Moreover, temporal variations in temperature tend to attenuate. In summer, the most important change is the temperature increase, albeit weaker than in winter. Even so, warming leads to a significant lengthening of the thermal growing season and an increase in the effective temperature sum.

\subsubsection{Southern Germany}

Compared to Finland, projected warming in southern Germany is distinctly weaker, only slightly exceeding the corresponding global average (Figure 2.12(a)). Moreover, the temperature increase is distributed quite evenly in the various seasons, with a peak in summer rather than in winter (Figure 2.13(a)). Again, the modelling uncertainty in warming is fairly large, the interval ranging from less than $1{ }^{\circ} \mathrm{C}$ to $3-4.5^{\circ} \mathrm{C}$. In annual precipitation, there is a minor increase, which is the residual of an increasing trend in winter and spring and a decreasing trend in summer and early autumn (Figures 2.12(b) and 2.13(b)). Nonetheless, inter-model agreement on the sign of the future precipitation response is low in all seasons. 
TIME SERIES OF CHANGE FOR SOUTHERN GERMANY

(A) TEMPERATURE, $50^{\circ} \mathrm{N}, 10^{\circ} \mathrm{E}$

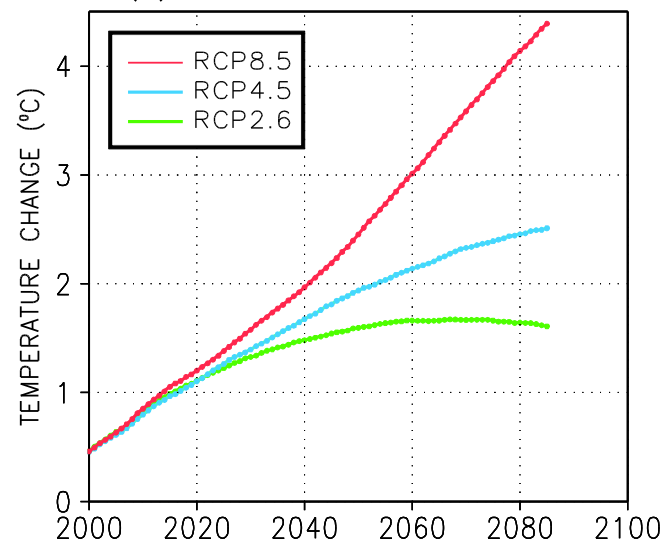

(C) SOLAR RADIATION, $50^{\circ} \mathrm{N}, 10^{\circ} \mathrm{E}$

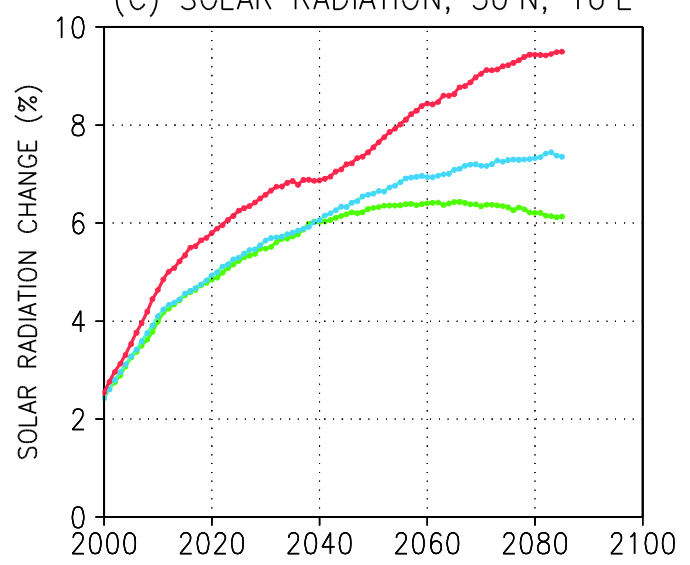

(B) PRECIPITATION, 50N, 10E

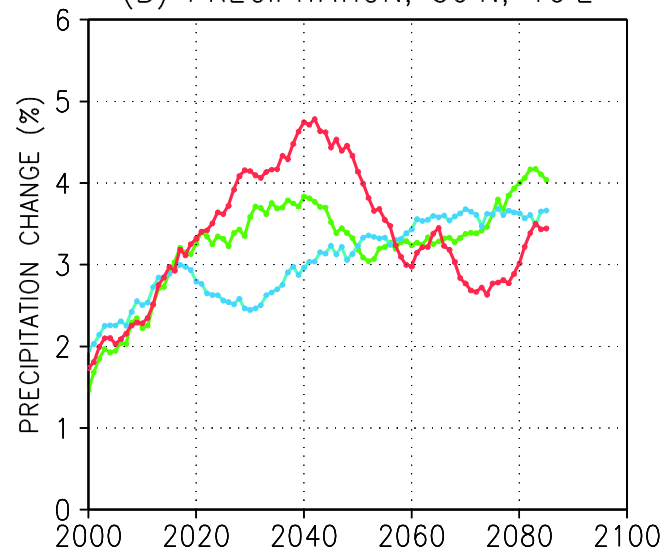

(D) RELATIVE HUMIDITY, $50^{\circ} \mathrm{N}, 10^{\circ} \mathrm{E}$

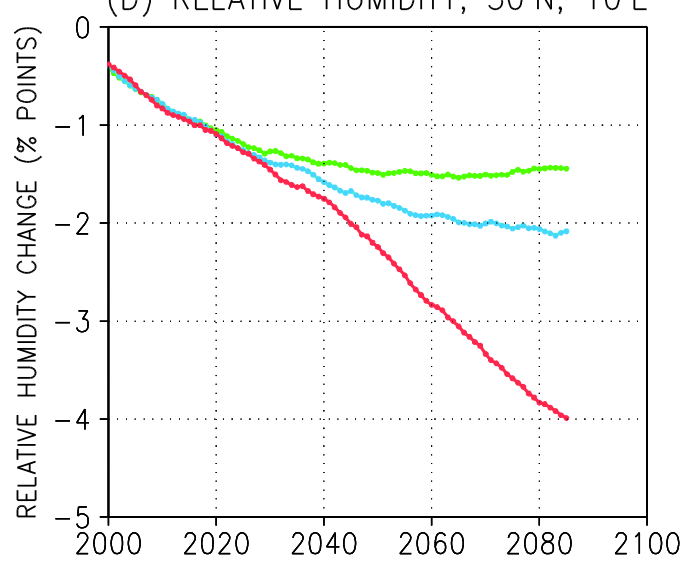

Figure 2.12: Projected annual mean changes relative to 1971-2000 in (a) mean temperature (in ${ }^{\circ} \mathrm{C}$ ), (b) precipitation (in \%), (c) incident solar radiation (in \%) and $(d)$ relative humidity (in percentage points) at $50^{\circ} \mathrm{N}, 10^{\circ} \mathrm{E}$ (southern Germany; the position is marked in Figure 2.1(a)). The time series are shown separately for the RCP2.6, RCP4.5 and RCP8.5 scenarios (see the legend).

Incident solar radiation is anticipated to increase and relative humidity to be reduced in all seasons apart from winter (Figures 2.13(c)-(d)). This is also reflected in the annual mean changes (Figures 2.12(c)-(d)). In late summer, the increase in solar radiation is quite material, about $10 \%$ according to the multi-model mean, with an uncertainty interval from 0 to $22 \%$. Note that southern Germany belongs to the area where the increase in the annual sum of incident radiation is largest in Europe (Figure 2.1(c)). 
(A) TEMPERATURE, $50^{\circ} \mathrm{N}, 10^{\circ} \mathrm{E}$

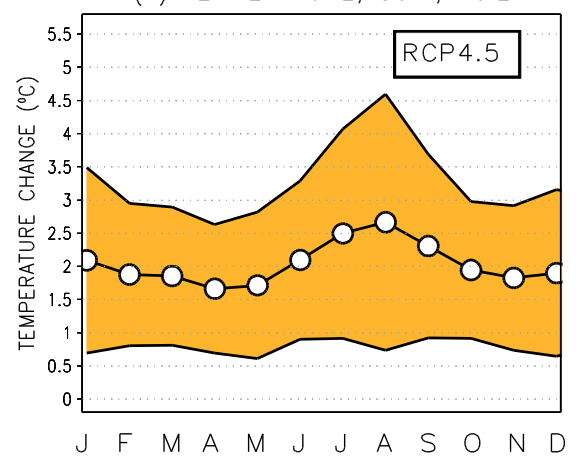

(C) SOLAR RADIATION, $50^{\circ} \mathrm{N}, 10^{\circ} \mathrm{E}$

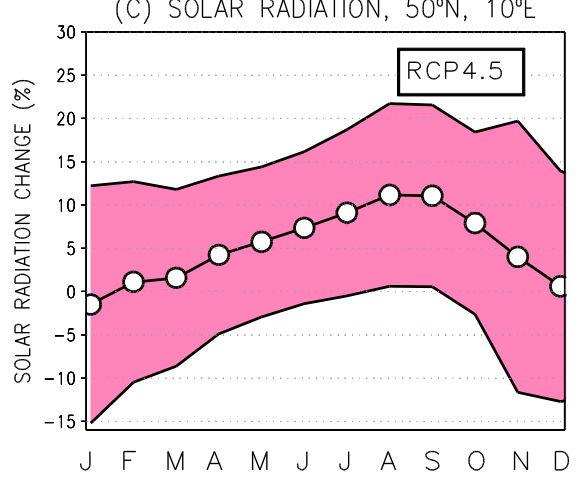

(E) TEMPERATURE STDEV, $50^{\circ} \mathrm{N}, 10^{\circ} \mathrm{E}$

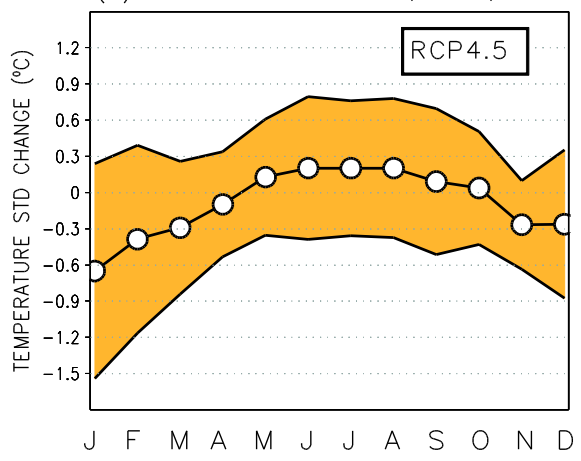

(B) PRECIPITATION, $50^{\circ} \mathrm{N}, 10^{\circ} \mathrm{E}$

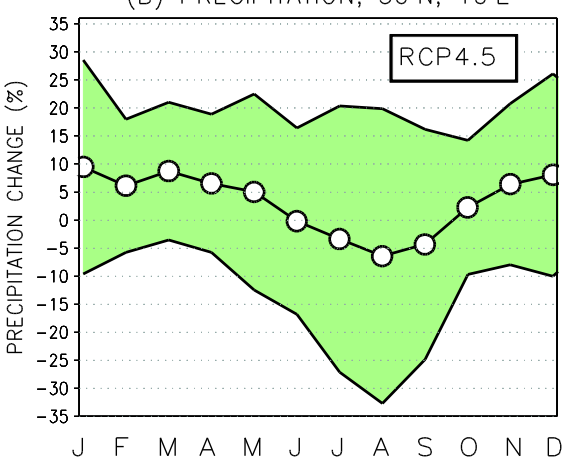

(D) RELATIVE HUMIDITY, $50^{\circ} \mathrm{N}, 10^{\circ} \mathrm{E}$

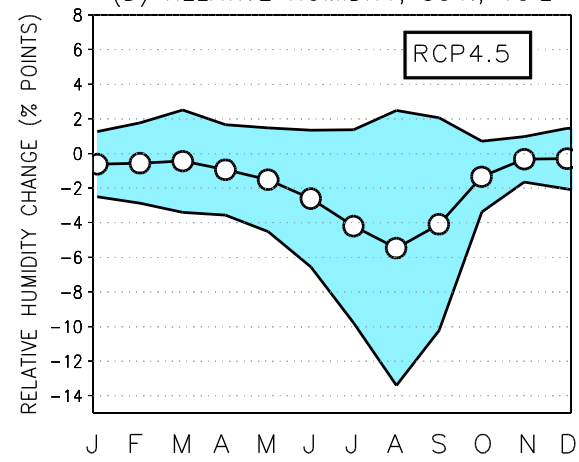

(F) PRECIPITATION STDEV, $50^{\circ} \mathrm{N}, 10^{\circ} \mathrm{E}$

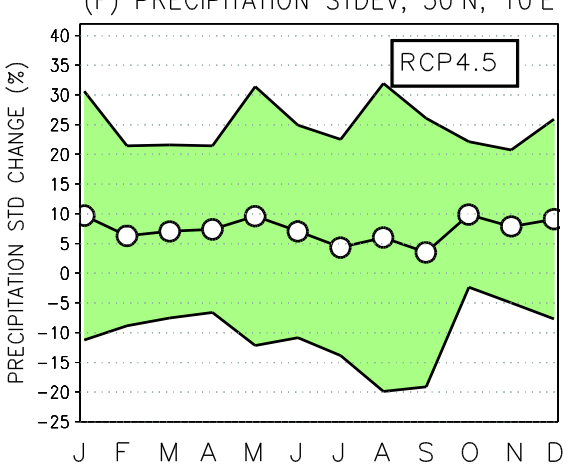

Figure 2.13: Projected monthly changes in (a) the mean temperature $\left(\right.$ in $\left.{ }^{\circ} C\right),(b)$ precipitation (in \%), (c) incident solar radiation (in \%) and (d) relative humidity (in percentage points) at $50^{\circ} \mathrm{N}, 10^{\circ} \mathrm{E}$ (southern Germany; the position is marked in Figure 2.1(a)) under RCP4.5 for the period 2040-2069, relative to 1971-2000. Corresponding changes in the temporal standard deviation of daily-mean temperature (in ${ }^{\circ} \mathrm{C}$ ) and precipitation (in \%) are shown in panels $(e)$ and $(f)$. The multi-model mean projections for individual calendar months $(J=$ January,..., $D=$ December $)$ are denoted by open circles. Shading shows the $90 \%$ uncertainty intervals for the projection.

In central Europe, both the decreasing precipitation and enhancing evaporation, induced by the higher temperatures and increasing solar radiation, act to reduce soil moisture in summer. This leads to a substantial drying in the soil, particularly in late summer (Figure 2.14). As a consequence, such dry-soil episodes that occur once per decade in the late-20th century climate will be experienced nearly every fourth year during the period 2040-2069 (Ruosteenoja et al., 2018). 


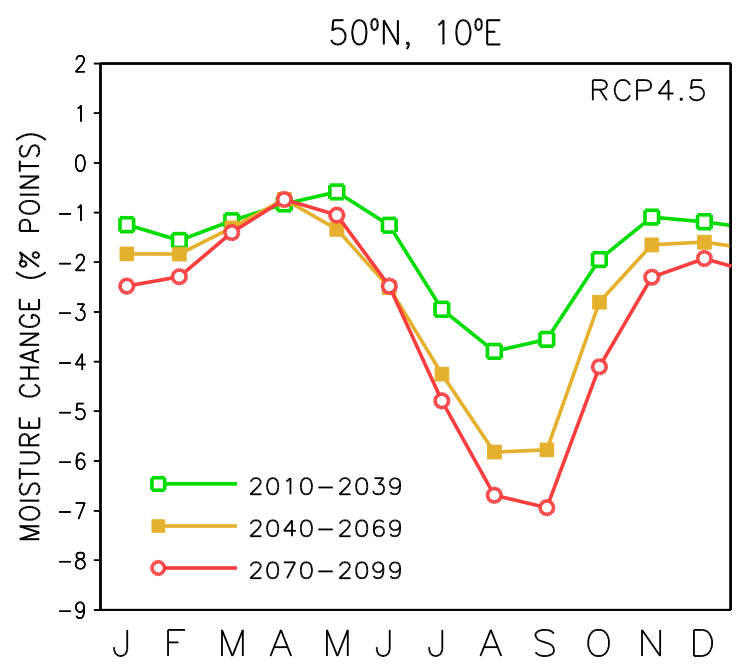

Figure 2.14: Multi-model mean monthly responses $(J=$ January, $F=$ February, ...) in near-surface (the uppermost $10 \mathrm{~cm}$ layer) soil moisture (in percentage points) for three future time spans (2010-2039, 2040-2069 and 2070-2099, relative to 1971-2000; see the legend) at $50^{\circ} \mathrm{N}, 10^{\circ} \mathrm{E}$ under the RCP4.5 scenario.

The temporal variability of temperature is projected to change fairly little, and the inter-model agreement on the sign of change is low (Figure 2.13(e)). Even so, it is likely that in winter the very coldest temperatures would warm somewhat more than the mean and maximum temperatures.

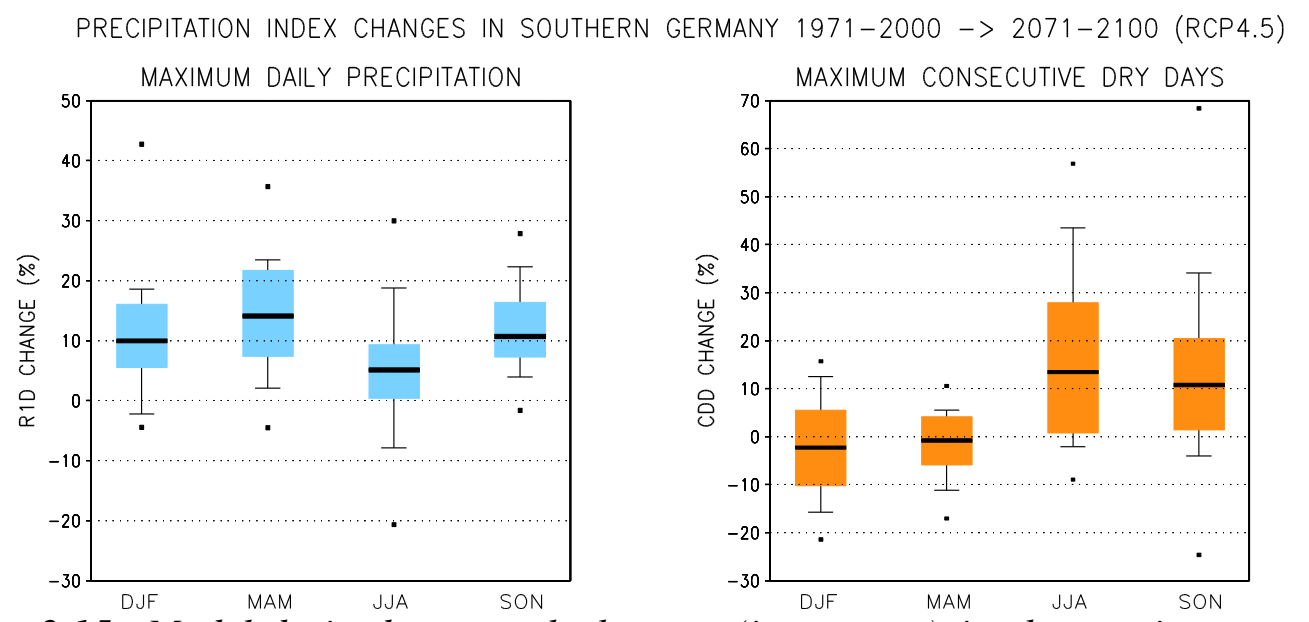

Figure 2.15: Model-derived seasonal changes (in percent) in the maximum one-day precipitation Rld (left panel) and the maximum number of consecutive dry days CDD (with precipitation $<1 \mathrm{~mm} /$ day; right panel) at $50^{\circ} \mathrm{N}, 10^{\circ} \mathrm{E}$ (southern Germany; the position is marked in Figure 2.1(a)) under RCP4.5 for the period 2071-2100, relative to 1971-2000. The coloured bars show the 25th to 75th percentile intervals of the change derived from the responses of 21 models. The corresponding 10th to 90th percentile intervals are depicted by whiskers and the minimum and maximum responses among the models by black dots. The black lines within the bars stand for the multi-model medians. The probability distributions are given separately for four seasons: December-February (DJF), March-May (MAM), June-August (JJA) and September-November (SON).

According to the multi-model mean estimate, temporal variability in precipitation would increase throughout the year, slightly so even in summer and early autumn when the mean precipitation is projected to decrease. Consequently, precipitation conditions will 
become more variable in summer and autumn; both the maximum 1-day precipitation and the length of dry periods increase in a majority of models (Figure 2.15). In the winter and spring, the largest 1-day precipitation totals likewise increase, as a matter of fact more pronouncedly than in summer, but most likely there is fairly little change in the lengths of dry periods.

Accordingly, in Germany climatic changes with negative impacts tend to accumulate for summer. Declining summer precipitation, in conjunction with rising temperatures, increasing solar radiation and lower relative humidities, lead to an exacerbating drought risk. This is explicitly visible in the decrease of soil moisture and an increase in the length of dry periods.

\subsection{Climate change impacts in Europe with focus on forest sector}

In Europe climate change is characterized by increasing precipitation in the northern parts of the continent and decreasing precipitation in the southern parts. During winter season warming is more pronounced at high latitudes than southern Europe whereas during the warm season also the Mediterranean region is expected to experience substantially higher temperatures (Figure 1.3). Dry regions will become drier particularly in summer (Figures 1.4 and 2.14). Sea level will continue to rise, and extreme events, like heat waves, heavy precipitation and drought, will occur more frequently and be more intense in the future.

The estimated impacts of climate change for different regions as compiled by the European Environment Agency (EEA) (2017) are shown in Figure 2.16. The estimated impacts can mainly be regarded as negative; however, in the Boreal region there are some positive impacts like increasing potential for forest growth and increase in crop yields.

When we look the impacts of climate change on forestry, both positive and negative impacts on forest structure, growth, composition, productivity and functioning are to be expected, depending on the type and geographical location of forest (EEA, 2016a). As a whole, in Europe it is likely that climate change will have a positive effect on wood production and wood supply due to warmer temperatures, longer growing season and increased $\mathrm{CO}_{2}$ concentration in the atmosphere. Tree growth and productivity are predicted to increase at high latitudes and altitudes. In other regions, changes may be positive in the beginning but negative in the mid and long term. For example, it is likely that Mediterranean regions will experience higher rates of tree mortality and forest fires when temperatures and the frequency of droughts increase (e.g., Kellomäki et al., 2008; Reyer et al., 2014). The possible increase of disturbances caused by weather phenomena like forest fires, wind damages and forest pests may cancel at least to some extent the climate change-induced productivity increase (Reyer et al., 2017a). The overall effect of climate change on forest resources requires still new and multidisciplinary research. Especially, a more thorough inclusion of weather disturbances into impact assessments requires substantial amount of research. 


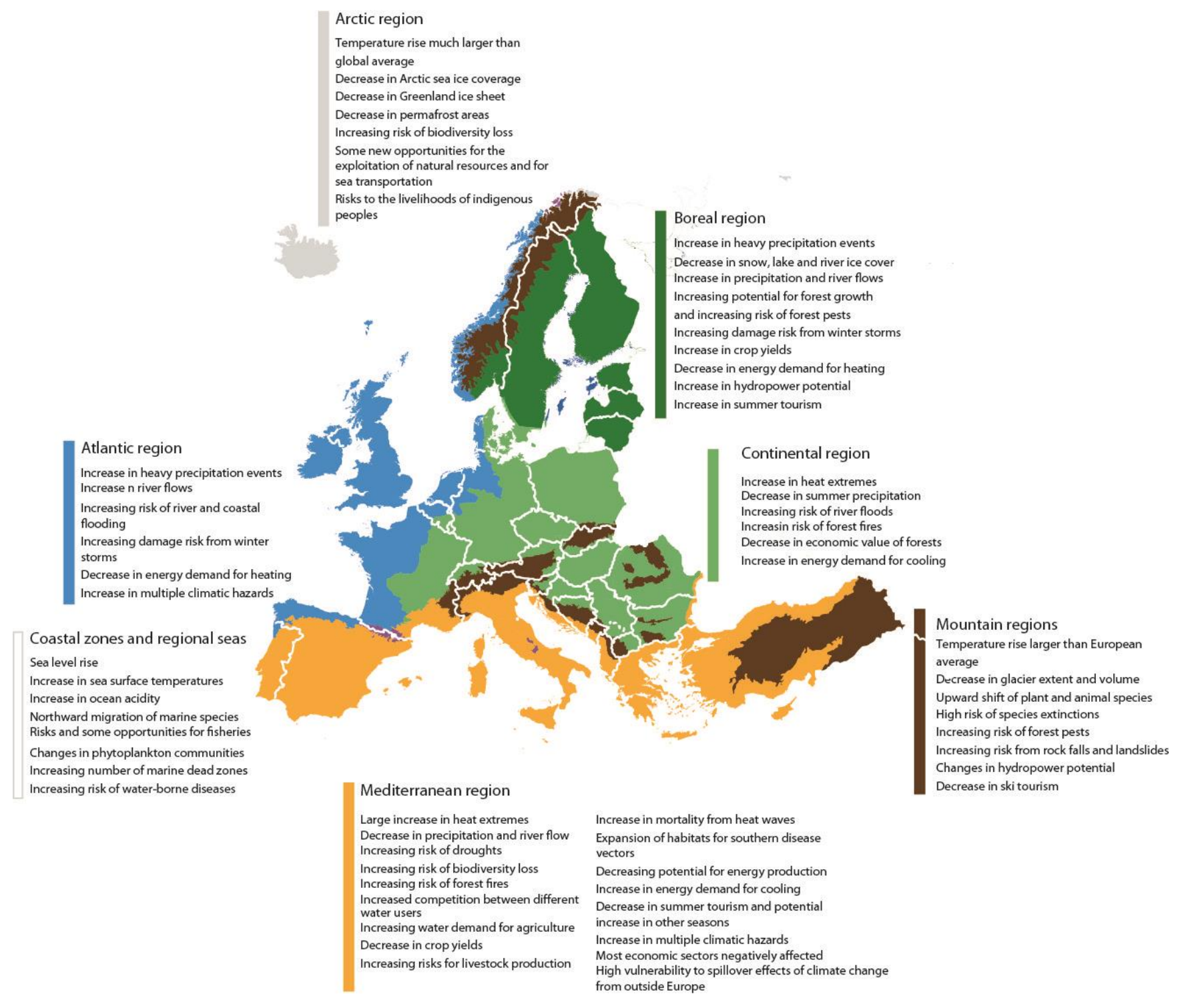

Figure 2.16: Summary of the impacts of estimated climate change at different regions in Europe (edited from EEA, 2017).

In Finland, climate change is predicted to increase forest growth especially in the northern parts of the country (Kellomäki et al, 2018). However, for Norway spruce in southern and central Finland, the shortage of water may have severe negative impacts on growth. To summarize, the differences between tree species are as follows: birch is benefitting most but spruce is suffering most seriously from the projected change, and pine is mainly benefiting but not as much as birch.

According to the energy and climate strategy, the use of Finnish forests could be up to 80 million $\mathrm{m}^{3}$ year ${ }^{-1}$. Forests are an important carbon sink, and large amounts of carbon is stored into wooden biomass and understory. When aiming at limiting global warming to below $2^{\circ} \mathrm{C}$, the current sinks of $\mathrm{CO}_{2}$ should be increased (IPCC, 2018). Finland is a highly forested country, and the national welfare depends largely on forest industry. The sustainable level of utilization of forest resources is currently discussed widely. This is also related to the EU's land use, land use change and forestry (LULUCF) regulation. The Finnish Climate Panel (Kalliokoski et al., 2019) reviewed six different models used for the estimation of carbon balance in forests and found out that the models produced very different predictions for the carbon balance, and none of the models was able to produce 
definitively reliable predictions for the future development of forests in Finland. More research is still needed in order to supplement our knowledge in this essential issue.

\subsection{Climate change induced risks to forests in Europe}

Observed changes in forest growth and also predictions are rather positive, especially for northern Europe. However, the weather-related disturbances may also have serious negative impacts on forests, and in this chapter we review the most important disturbance agents.

\subsubsection{Varying wind damage risk}

Wind is the dominant abiotic cause of forest damages in Europe. In the past few decades, wind storms have damaged a significant amount of timber and caused large economic and ecological losses in forestry (Schelhaas 2008; Seidl et al., 2014; Reyer et al. 2017a). In Finland, strong winds have damaged over 24 million $\mathrm{m}^{3}$ of timber during different winter and summer storms since 2000 (e.g. Zubizarreta-Gerendiain et al., 2017). The increasing amount of damages in the European forests may at least partially be explained by the increasing volume of growing stock and changes in forest structure (e.g., age and tree species). These are related to changes in forest management practices. The projections of future climate indicate only quite modest changes in extreme wind speeds for northern Europe (Figure 2.10; Ruosteenoja et al., 2019). Nevertheless, decreasing soil frost may increase wind damage risk (section 2.3.3).

\subsubsection{Insect pests}

Changes in the frequency and severity of pest and disease outbreaks are very likely in the future. Climate change is expected to make conditions more favourable for many insect pests. An extensive summary of the impacts of climate change on the Finnish forest insect pests was recently published by Asikainen et al. (2019), and this chapter is largely based on that report.

In Europe, bark beetles have, on average, destroyed 2.8 million cubic metres of wood annually during 1950-2000 (Schelhaas et al., 2003). The most significant insect pest in the European forests is the European spruce bark beetle (Ips typographus) (e.g., Christiansen and Bakke, 1988). This species lives generally in wind-damaged Norway spruces, but after extensive wind damage or drought, intensive spruce bark beetle outbreaks may exist (Marini et al., 2013, 2017). During these kinds of outbreaks, the spruce bark beetles can also attack healthy spruce trees.

In Finland, spruce bark beetle has been traditionally a univoltine (one generation per summer) species existing in low numbers, but within the recent years, it has become more abundant. Particularly, the spruce bark beetle populations increased after the warm summer of 2010 (Siitonen and Pouttu, 2014). This was partly because there were a lot of wind-damaged trees in forests after the severe thunderstorms of the summer of 2010 (Viiri et al., 2011). Secondly, drought stress had weakened the defence of spruces against the insect pests. Thirdly, as a result of the exceptionally warm thermal growing season in 2010, spruce bark beetles were able to produce a second generation during the same year (Pouttu and Annila, 2010). As the next summer was equally warm, and windstorm Tapani in December 2011 caused additional extensive damage in the forests, conditions for the growth of spruce bark beetle populations continued to be favourable.

Increase in summer temperatures is favourable for spruce bark beetles because the species can generate two generations during one summer if the growing degree day (GDD) sum exceeds approximately $1500{ }^{\circ} \mathrm{C}$ days. In the 20th century, annual GDD sums in 
Southern Finland varied in typical summers mainly between 1300 and $1400{ }^{\circ} \mathrm{C}$ days and only occasionally exceeded the threshold of $1500{ }^{\circ} \mathrm{C}$ days. In Southern Sweden, for instance, the thermal growing season is longer and the GDD sums are thus higher. Consequently, spruce bark beetle is there a bivoltine (two generations per summer) species (Öhrn et al., 2014).

Already during the early 21st century, in Southern Finland the GDD sums have tended to exceed the threshold of $1500{ }^{\circ} \mathrm{C}$ days in many years. The summer of 2018 was record warm, and the highest GDD sums in Southern Finland reached $1900{ }^{\circ} \mathrm{C}$ days, corresponding to typical values in Poland (Wypych et al., 2017). GDD sums exceeded $1500{ }^{\circ} \mathrm{C}$ days up in the north to Northern Savonia and Southern Ostrobothnia. Climate projections indicate that this kind of GDD sums would be typical at some time during the second half of the 21st century (Ruosteenoja et al., 2011, 2016; Figure 2.9). Moreover, as the climate warming continues, it will soon become very unlikely to have a thermal growing season that is cool according to current climate statistics.

Figure 2.17 illustrates that already in the current climate spruce bark beetle is capable to produce two generations per year every second summer in Southern Finland. In midcentury, annual GDD sum is projected to exceed $1500{ }^{\circ} \mathrm{C}$ days in $8-9$ summers out of ten in the south and about 5-7 summers out of ten in the central parts of Finland. In the late 21 st century, spruce bark beetle is expected to produce second generation occasionally even in Lapland, and in the south the species would clearly become bivoltine.

$\begin{array}{llccc} & \text { Regions } & \text { 2010-2039 } & \text { 2040-2069 } & \text { 2070-2099 } \\ \text { RPC 4.5 } & \text { Mean_A } & 62,2 & 84,6 & 91,4 \\ \text { RPC 4.5 } & \text { Mean_B } & 29,1 & 58,7 & 73,4 \\ \text { RPC 4.5 } & \text { Mean_C } & 10,3 & 33,6 & 51,1 \\ \text { RPC 4.5 } & \text { Mean_D } & 1,1 & 8,3 & 18,1 \\ \text { RPC 4.5 } & \text { Mean_E } & 0,1 & 1,0 & 3,0 \\ & \text { Regions } & 2010-2039 & 2040-2069 & 2070-2099 \\ \text { RPC 8.5 } & \text { Mean_A } & 59,4 & 90,9 & 99,3 \\ \text { RPC 8.5 } & \text { Mean_B } & 33,1 & 75,9 & 96,7 \\ \text { RPC 8.5 } & \text { Mean_C } & 12,9 & 53,9 & 87,5 \\ \text { RPC 8.5 } & \text { Mean_D } & 1,7 & 21,6 & 61,2 \\ \text { RPC 8.5 } & \text { Mean_E } & 0,1 & 5,1 & 34,9\end{array}$

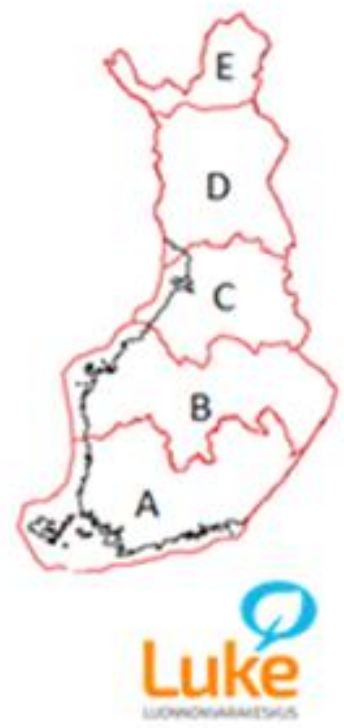

Figure 2.17: The probability (in percent) of the annual growing degree day sum exceeding $1500{ }^{\circ} \mathrm{C}$ days in different regions of Finland during the periods 2010-2039, 2040-2069 and 2070-2099 under the RCP4.5 and RCP8.5 scenarios. Adapted from Asikainen et al. (2019).

In other parts of Europe, the population density of spruce bark beetles has recently increased as well. In Sweden, windstorm Gudrun damaged 70 million cubic metres of wood in January 2005 (Bengtsson and Nilsson, 2007), and in the subsequent spruce bark beetle outbreak additional 4 million cubic metres of wood were destroyed (Långström et al., 2009). In Poland, spruce bark beetles have destroyed annually on average 1 million cubic metres of wood during the 1980s and 1990s (Grodzki, 1999). At the moment, the situation is worst in the Czech Republic where a series of years favourable for spruce bark beetle has occurred since 2003 (Krejzar, 2018). An unprecedented spruce bark beetle 
outbreak emerged in 2017, and as a result, the timber market in the Czech Republic has collapsed since bark beetle damage has exceeded the annual need for timber in the country, and there are not enough forest machinery and resources to fell even all the damaged trees.

In the future, spruce bark beetle is expected to benefit from climate change in Europe (Seidl et al., 2008, 2009; Hlásny et al., 2011). The development of the species is strictly regulated by air temperature (Annila, 1969). Traditionally, the species has been univoltine in Southern Finland, for instance, and at higher elevations in Central Europe as well while in most of Central Europe it has been bivoltine. Already in the near future in Central Europe, significant three-generation regimes are projected to appear. By the end of the 21 st century, the three-generation regime is expected to occur over all the existing coniferous stands in the Czech Republic, for instance (Hlásny et al., 2011).

In addition to the spruce bark beetle, many other insect pests are expected to benefit from climate change (Asikainen et al., 2019). The damage caused by the common pine shoot beetle (Tomicus piniperda) and the large pine weevil (Hylobius abietis) are both expected to increase. The populations of the European pine sawfly (Neodiprion sertifer) may increase in eastern and northern Finland due to rising winter temperatures and in southern and western Finland due to increasing summer drought (Virtanen et al., 1996; Nevalainen et al., 2015).

Heterobasidion species are globally the most important wood-decay fungus for conifers. Woodward et al. (1998) estimated that within the European Union, damage caused by Heterobasidion species accounts for 800 million euros annually. In Finland, two species of Heterobasidion occurs, Heterobasidion annosum and Heterobasidion parviporum. Heterobasidion annosum is considered to be economically the most important forest pathogen in the Northern Hemisphere. It causes root and butt rot diseases on pine trees. In Finland, it is most common in southeastern parts of the country. In our country, Heterobasidion parviporum is a more common species. It causes root and butt rot on spruces. In Southern Finland, approximately 15-20\% of spruces suffers from the root rot. Heterobasidion parviporum occurs sporadically also in Northern Finland, although root and butt rot diseases of conifers are there caused mainly by other decay fungi than Heterobasidion (Müller et al., 2018). Increasing temperatures increase the spore formation of the Heterobasidion parviporum, and it is expected that the share of infected spruces will increase in the future (Pukkala et al., 2005; Müller et al., 2014). In addition, the projected loss of soil frost may increase root damage in forest harvesting, making trees more vulnerable for wood-decay fungus. Heterobasidion annosum is likewise expected to become more abundant at least in Southern Finland. In Northern Finland, Heterobasidion annosum is presently nearly absent for an unknown reason (Müller et al., 2018).

One classic insect pest in Central Europe is the nun moth (Lymantria monacha). Between the years 1853 and 1863, caterpillars of the nun moth destroyed 147 million cubic metres of wood in Russia and East Prussia (Bejer, 1988). Most of this area was afterwards converted into agricultural land. The abundance of the nun moth has varied cyclically from a decade to decade without a clear connection to weather conditions (Haynes et al., 2014). However, the northern distribution limit of the nun moth is restricted by the minimum winter temperatures as the eggs of the species do not survive in temperatures colder than approximately $-30{ }^{\circ} \mathrm{C}$ (Fält-Nardmann et al., 2018). Before the 1990s, temperatures colder than this threshold were common enough so that in Finland small populations of the nun moth occurred only in the southwestern archipelago. However, after the 1990s, the abundance of the nun moth in Finland has increased approximately 100-fold, and the species is nowadays common widely in the southern parts of the country (Leinonen et al., 2017). It is estimated that the northern distribution limit of the nun moth can still shift approximately $300 \mathrm{~km}$ northwards if the mean temperature increases by additional $5{ }^{\circ} \mathrm{C}$ (Fält-Nardmann et al., 2018). Forest damages caused by the nun moth have been already 
documented in Estonia (Voolma et al., 2014), and minor damages have been reported also in the southwestern archipelago of Finland (Heino and Pouttu, 2014).

A close relative to the nun moth, the gypsy moth (Lymantria dispar), is also a wellknown insect pest. While the nun moth damages mainly conifers, especially spruce forests, caterpillars of the gypsy moth feed on deciduous trees. The gypsy moth is a widespread species in Central Europe and nowadays common also in the Baltic states. It is moreover an introduced species in North America where it has caused extensive damage in oak forests (Elkinton and Liebhold, 1990; Weseloh, 2003; McManus and Csóka, 2007). In Eurasia, outbreaks of the gypsy moth occur approximately once in every ten years (McManus and Csóka, 2007; Hlásny et al., 2016). In Finland, before the 2010s the gypsy moth had occurred only as an extremely rare migrant but during the recent years, a few populations might have already appeared at the southern coast. Overwintering eggs of the gypsy moth are even more vulnerable to extreme cold temperatures than the eggs of the nun moth but. Nonetheless, in the future, winters are projected to became mild enough for the formation of gypsy moth populations in Southern Finland (Fält-Nardmann et al., 2018; Neuvonen et al., 2018).

To conclude, most of insect pests benefit from climate change because their development is closely regulated by air temperature. In the Finnish flora, Norway spruce is the tree species most sensitive to climate change and increasing drought occurrence may weaken its defence against insect pests. In addition to already existing insect pests and fungi, new invasive species can be accidentally introduced by international plant trade (Lilja et al., 2011; Hantula et al., 2014).

\subsubsection{Less soil frost}

Soil frost is affected, e.g., by the soil properties and water content. The most important meteorological factors controlling soil frost are air temperature and the snow depth. Snow cover is an efficient insulator, and in Finland, for instance, soil frost penetrates typically deeper in the western than eastern parts of the country although winters are usually milder in the west. This is because snow cover tends to be thicker in the east. Due to global warming mean temperature is projected to increase, but in many areas snow cover is simultaneously projected to decrease and this might partially cancel out the impact of increasing temperature on soil frost.

Most recently the impact of climate change on soil frost conditions in Finland has been studied by Lehtonen et al. (2019). Based on that study, the mean annual number of days with modelled soil frost thickness exceeding $20 \mathrm{~cm}$ in Finland is shown in Figure 2.18 , separately for mineral soils (clay or silt) and peatlands. The results are shown for the reference period 1981-2010 and for the future periods of 2021-2050 and 2070-2099 under the RCP4.5 and RCP8.5 scenarios. According to these results, the soil frost season on mineral soils is projected to shorten by about one month from 1981-2010 to 2021-2050. By the end of century, the shortening is most likely about two months under the RCP4.5 scenario and approximately three months if the RCP8.5 scenario realizes. In Southern Finland, this means that the length of the soil frost season would decrease by more than $50 \%$ on average. On peatlands soil frost does not penetrate as deep as on mineral soils, and in the late 21 st century peatlands in Southern Finland are expected to remain virtually unfrozen in most of winters.

The loss of soil frost is expected to hamper wintertime logging. The bearing capacity of forest sites is clearly higher during frozen than unfrozen conditions. In addition, small forest truck roads having light foundations do not bear heavy timber trucks in wet road sections unless the soil is frozen (Kaakkurivaara et al., 2015). Operations in poorly bearing conditions increase rut formation on forest floor and tend to cause damage to tree roots 
and stems (Sirén et al., 2013; Pohjankukka et al., 2016). Moreover, fuel consumption in the harvesting increases. This holds also for fuel consumption in timber transportation if the truck roads are in poor condition (Svenson and Fjeld, 2016).

\section{Mineral soils}

(a) 1981-2010
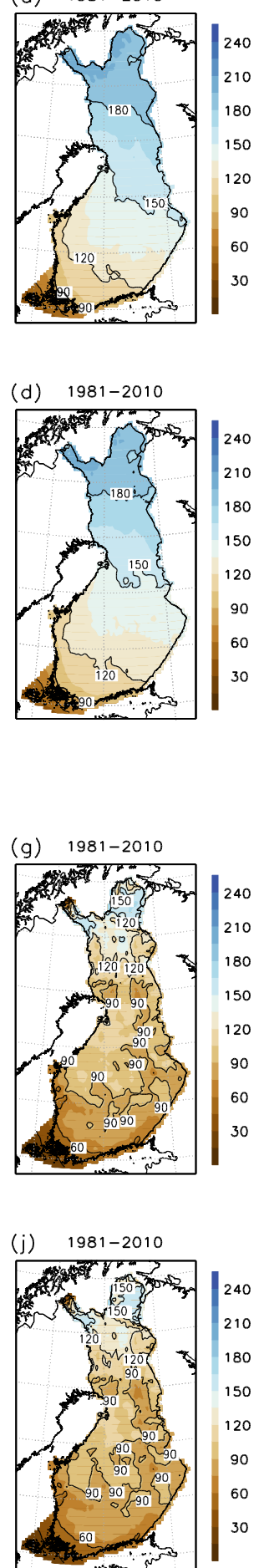

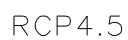

RCP 4.5

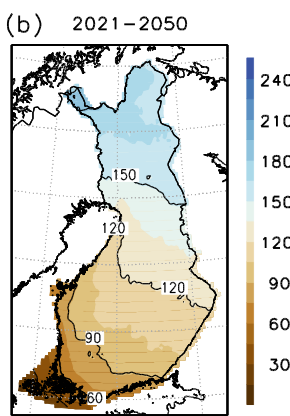

RCP 8.5

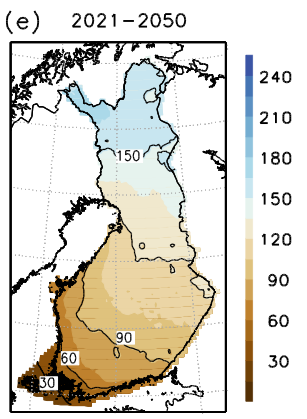

Peatlands

RCP4.5

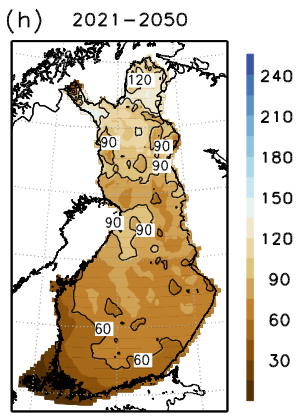

RCP 8.5

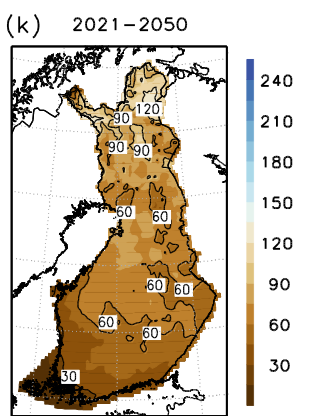

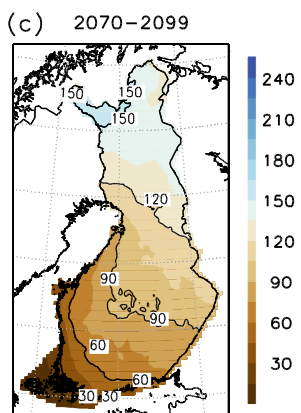
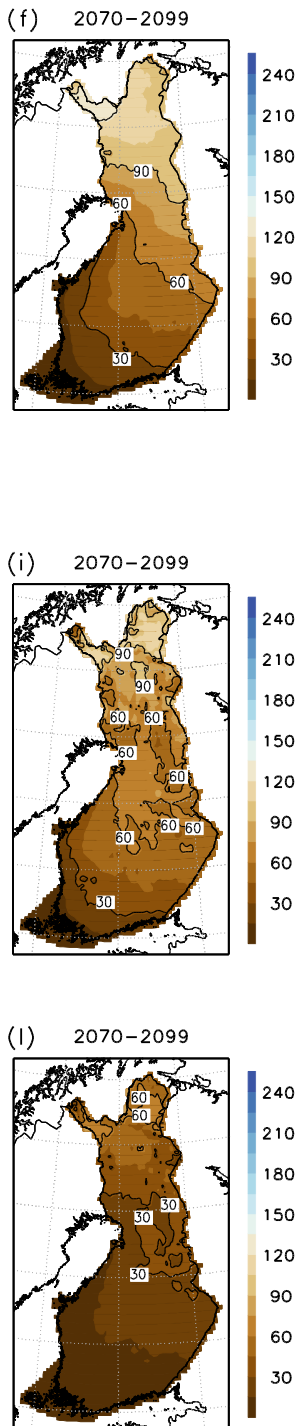

Figure 2.18: Mean annual number of soil frost days (soil frost depth at least $20 \mathrm{~cm}$ ) on mineral soils and on peatlands during the periods 1981-2010, 2021-2050 and 2070-2099 as evaluated based on six climate model simulations. 
Harvesting conditions are particularly difficult on unfrozen drained peatlands because of their inherently low ground-bearing capacity. Thus, on these sites logging is generally conducted during winter when the soil is frozen (Ala-Ilomäki et al., 2011). On the other hand, a more intensive utilization of peatland forests has the largest potential in increasing the wood harvesting. This might be difficult as peatland forests are expected to lose soil frost during the forthcoming decades.

The results of Lehtonen et al. (2019) are in accordance with earlier studies (e.g., Venäläinen et al., 2001; Kellomäki et al., 2010): the effect of increasing temperature mostly outweighs the impact of decreasing snow cover when considering expected changes in soil frost conditions. In particular the soil frost season is projected to shorten as in a warmer climate the soil freezes, on average, later in autumn and melts earlier in spring. Nevertheless, according to Kellomäki et al. (2010), in most winters the maximum soil frost depth on mineral soils would in mid-21st century still exceed $50 \mathrm{~cm}$ even in Southern Finland. On the other hand, from January to March the soil could be almost unfrozen for half of the time. In central and northern parts of the country, the typical soil frost depth on mineral soils in late winter would still be around one meter in the late 21st century (Kellomäki et al., 2010).

In snow-free surfaces, like in forest truck roads if they are kept snow-free, the soil frost depth is approximately proportional to the square root of the cumulative frost sum (e.g., Gregow et al., 2011). In these kinds of environments, the increasing temperatures thus straightforwardly lead to diminishing soil frost.

\subsubsection{Drought leading to higher forest fire risk}

Increase in the frequency and severity of summer droughts will have an impact on forest fire danger. In the Mediterranean region, large forest fires occur almost every summer, and huge fires are not rare either in the boreal forests of Russia and Canada (e.g., Flannigan et al., 2009; Mei et al., 2011; Vivchar, 2011; Gonçalves and Sousa, 2017).

Also, in Finland, numerous wildfires occur every year, but the average size of the fires is small, approximately 0.5 ha. Consequently, the annual burned area, on average, is nowadays historically low (Wallenius, 2011). This is threatening biodiversity as fire is a natural phenomenon in the process of forest regeneration (e.g., Esseen et al., 1997). The small average size of fires in Finland is due to the effectiveness of fire suppression. Fire survey flights contribute to the early detection of fires, and the dense forest road network aids fire fighters to reach and suppress the fires (e.g., Lehtonen et al., 2016a). In rural areas, the suppression of fires is largely conducted by local volunteer fire departments. Moreover, the Finnish landscape is characterized by numerous lakes and swamps creating natural obstacles for the fires. On the other hand, many other boreal regions are characterized by large homogenous forest areas. However, large fires are still possible in Finland. Recently, in environmental conditions similar to Finland, large forest fires have occurred in Sweden in the summers of 2018 and in 2014. In 2014, a single fire in Västmanland burned 14000 ha of forest (Länsstyrelsen i Västmanlands län, 2015).

Fire danger is often assessed with fire danger indices. One of the most-widely used index system is the Canadian forest-fire weather index (FWI) system (Van Wagner, 1987). The FWI system was used, e.g., by Groenemeijer et al. (2016) in estimating the impact of climate change on forest fire risk throughout Europe during the 21st century. In the southern parts of the continent, the meteorological fire danger is projected to increase significantly already by the mid-21st century (Figure 2.19). Towards the end of the century, it is much more likely that fire danger increases than decreases also in the north. The results of another study (Lehtonen et al., 2016a) indicated that the annual burned area could substantially increase in Finland if the connection between the fire danger and the 
fire activity remains similar as currently. On the other hand, as the burned area in Finland has been small during the recent decades, even a single conflagration could burn as much forest as all the fires have burned during the last 10 or 20 years in total. Hence, it is uncertain if the increasing fire danger indeed results in large fires, but the probability for a fire that could escape for a much larger fire than experienced during the recent decades is expected to increase. Nevertheless, the variations in the occurrence of fires cannot be predicted by climate forcing alone (Bowman et al., 2009). Other aspects, such as human behaviour should be taken into account as the large majority of fires, generally more than $90 \%$, is caused by human activities (Ganteaume et al., 2013).

\section{Daily probability of Fire Weather Index $>20$}
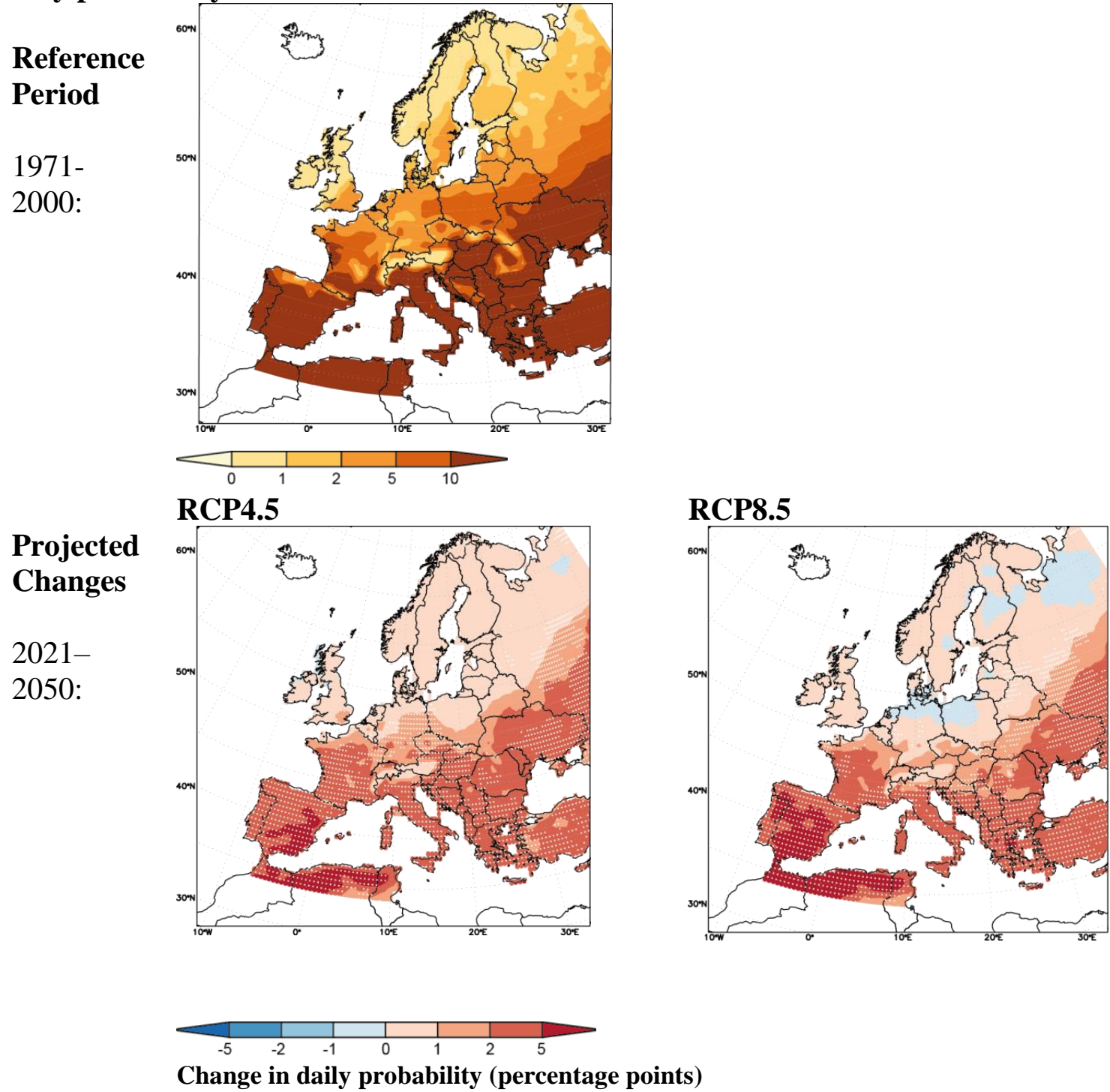

Figure 2.19: Multi-model mean daily probability (\%) of the fire weather index (FWI) value exceeding 20 during 1971-2000 (top). In the bottom row, multi-model mean change in the daily probability of FWI value exceeding 20 (in percentage points) is shown under the RCP4.5 (left) and the RCP8.5 scenarios (right). White dots denote a change significant at the $5 \%$ level. Adapted from Groenemeijer et al. (2016).

In regions suffering from aridity, like the Mediterranean basin, vegetation productivity may act as a limiting factor for fires (Migliavacca et al., 2013). In this kind of regions, the fire activity can thus be estimated to increase less than could be deducted purely on the basis of fire danger indices. However, even when taking into account the ecosystem 
functioning, in absolute terms the burned area is still predicted to increase in Europe particularly in the Mediterranean basins, in the Balkan regions and in Eastern Europe (Migliavacca et al., 2013). In relative terms, the increase in burned area is in Southern Europe most likely approximately $15 \%$ from the late 20th century to the mid-21st century. According to that study, for the same period in Central Europe, the change is more than $50 \%$ and in Northern Europe approximately 100\%, although in hectares the increase is projected to be largest in the south.

In accordance with the above-mentioned study, Turco et al. (2018) recently estimated that taking into account the productivity alterations under changing climatic conditions roughly halve the fire-intensifying signals in the Mediterranean Europe. They estimated the future burned area under the $1.5,2$ and $3{ }^{\circ} \mathrm{C}$ global warming scenarios and found out that the higher the warming level is, the larger is the increase of the burned area, ranging from approximately $40 \%$ to $100 \%$ across the scenarios.

\subsubsection{Snow damage risk}

Crown snow load consists of snow and rime attached tightly to tree crowns and other structures. The accumulation of snow on tree branches is dependent on meteorological conditions which are further modified by topography. Typical forms of snow damage under extreme snow-loading include stem breakage and bending or leaning of stems, but trees can also be uprooted if the soil is unfrozen (Petty and Worrell, 1981; Valinger et al., 1994; Nykänen et al., 1997). As in the case of wind damage, snow-damaged trees can furthermore disrupt power transmission by bending over or leaning on power lines. In addition, snow-damaged trees are susceptible to insect attacks and other kinds of consequential damage (Schroeder and Eidmann, 1993; Schlyter et al., 2006).

In Finland, snow is one of the most important abiotic disturbance agents reducing stand quality in forests. According to a survey conducted by the Finnish Forest Research Institute from 2009-2013, snow damage had occurred on 7\% of the productive forest land (Korhonen et al., 2017). At a European level, estimates of the amount of timber damaged by snow during a typical year vary from 1 million $\mathrm{m}^{3}$ to 4 million $\mathrm{m}^{3}$ (Nykänen et al., 1997; Schelhaas et al., 2003).

It has been long known that forests at high altitudes are most prone to snow damage (e.g., Heikinheimo, 1920). In Finland, the weight of snow loads on trees tends to increase approximately linearly with the terrain elevation (Jalkanen and Konôpka, 1998). In Northern Europe, snow damages are common already in areas located higher than 100 metres above the sea level whereas in Central Europe, altitudes of 500-900 metres are generally associated with the highest incidence of snow damage (Nykänen et al., 1997). The region of Kainuu is considered the most vulnerable area for snow damage in Finland (Solantie, 1994). Other high-risk regions include North Karelia and Lapland.

The impact of climate change on the snow-load risk can be estimated by using snow load models driven by climate model data. Groenemeijer et al. (2016) estimated the impact of climate change on several meteorological and hydrological hazards in Europe during the ongoing century. In estimating the future changes in heavy snow loads, they applied a snow load model developed and used operationally at the Finnish Meteorological Institute (Lehtonen et al., 2014). The climate data used in snow-load calculations originated from six different model simulations. Based on their results, heavy snow loads occur in Europe most frequently in the mountainous regions and in north-eastern Europe (Figure 2.20). Future projections for the mid-21st century indicate slightly decreasing probability for heavy snow loads over most of Europe. However, in northern Scandinavia, Finland and north-western Russia, the probability for heavy snow loads is widely expected to increase. These projected changes are, nevertheless, rather small and statistically not significant. 
Lehtonen et al. (2016b) studied the impact of climate change on heavy snow loads focusing only on Finland. Despite of some limitations in the study, their results largely corresponded with those by Groenemeijer et al. (2016), implying potentially increasing risk for snow damage in eastern and northern Finland, particularly in the regions of North Karelia, Kainuu, Koillismaa and Lapland. In southern and western Finland, on the other hand, snow loads on tree crowns were projected to decrease.

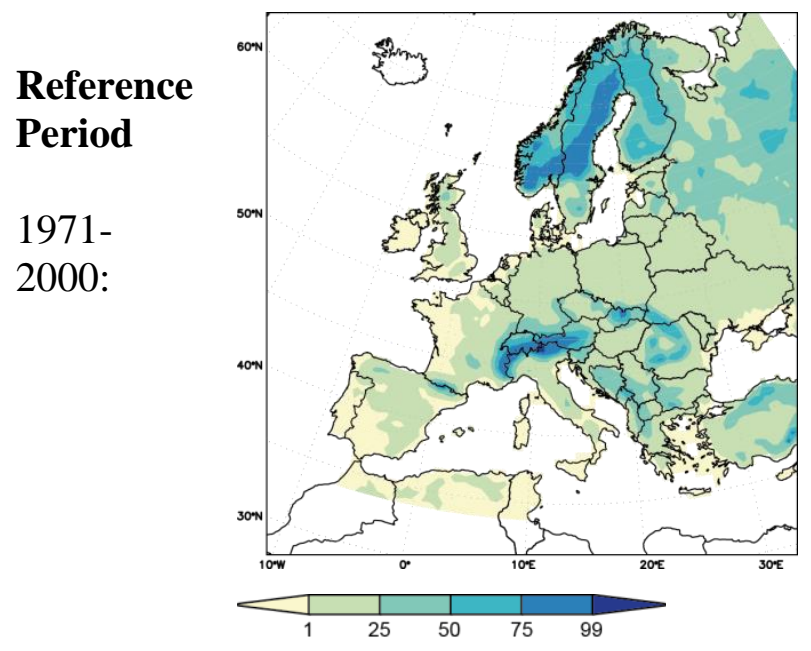

Annual probability (\%)

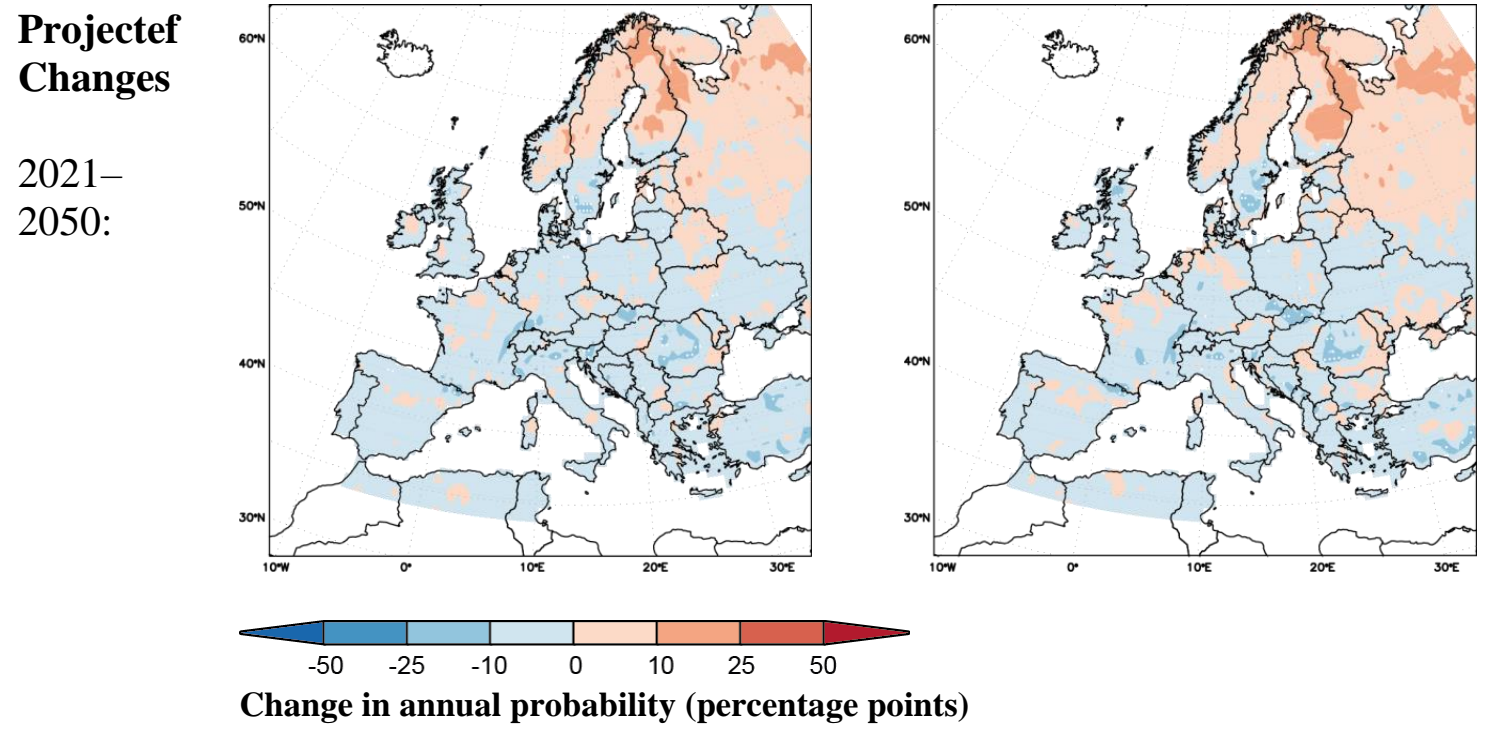

Figure 2.20: Multi-model mean annual probability (\%) of snow load exceeding $20 \mathrm{~kg} \mathrm{~m}^{-2}$ during 1971-2000 (top). In the bottom row, multi-model mean change in the annual probability (in percentage points) is shown under the RCP4.5 (left) and the RCP8.5 scenarios (right). White dots denote areas with a change significant at the $5 \%$ level. Adapted from Groenemeijer et al. (2016). 


\section{Climate change and impacts in Uruguay}

\subsection{Projected change of climate in Uruguay}

In Uruguay, projected changes in climate are fairly moderate. Temperature increase is likely to be smaller than the global mean increase of temperature (see Figures 3.3(a) and 1.2). According to the multi-model mean projection under RCP4.5, monthly mean temperatures increase by $1.2-1.5^{\circ} \mathrm{C}$ by the period $2040-2069$ (Figure 3.4(a)). The corresponding inter-model uncertainty interval ranges from less than $0.5^{\circ} \mathrm{C}$ to $1.8-2.4^{\circ} \mathrm{C}$.
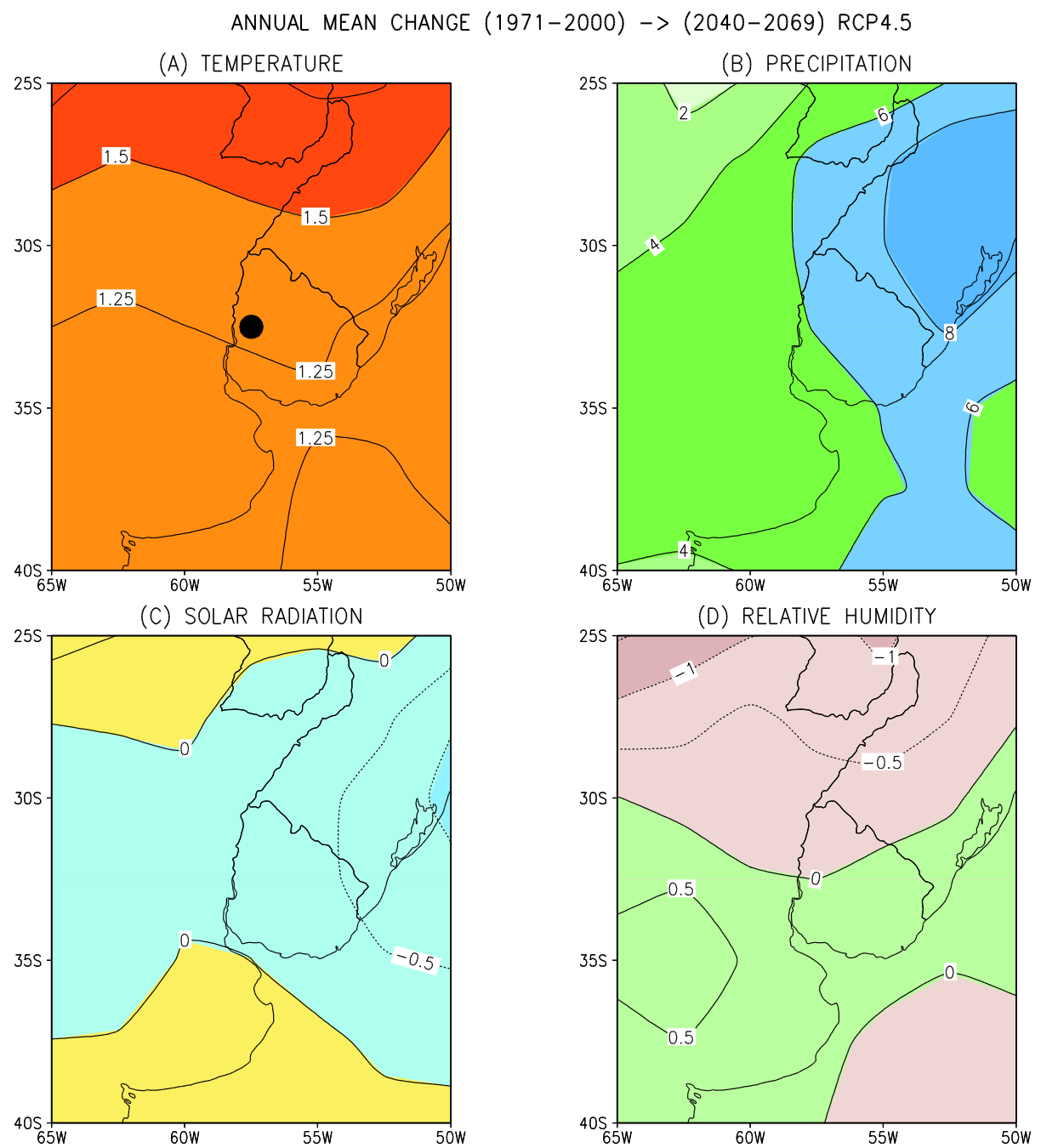

Figure 3.1: Projected changes in annual mean (a) temperature $\left(\right.$ in $\left.{ }^{\circ} \mathrm{C}\right)$, (b) precipitation (in \%), (c) incident solar radiation (in \%) and $(d)$ relative humidity (in percentage points) in Uruguay and its adjacent areas from the period 1971-2000 to 2040-2069 under RCP4.5. The position of the grid point $32.5^{\circ} \mathrm{S}, 57.5^{\circ} \mathrm{W}$ examined in the more detailed analyses is marked by a dot in panel (a).

For precipitation, the best-estimate projection is an increase of about $10 \%$ in Southern Hemisphere summer and autumn (from December to June), while from July to November precipitation totals remain nearly unchanged. This leads to an increase of about $6 \%$ in annual precipitation (Figure 3.1(b)). Considering the inter-model differences, however, the sign of change cannot be firmly established in any season. The uncertainty interval of the change ranges from about $-20 \%$ to $+40 \%$ in autumn and from $-30 \%$ to $+20 \%$ in spring. 

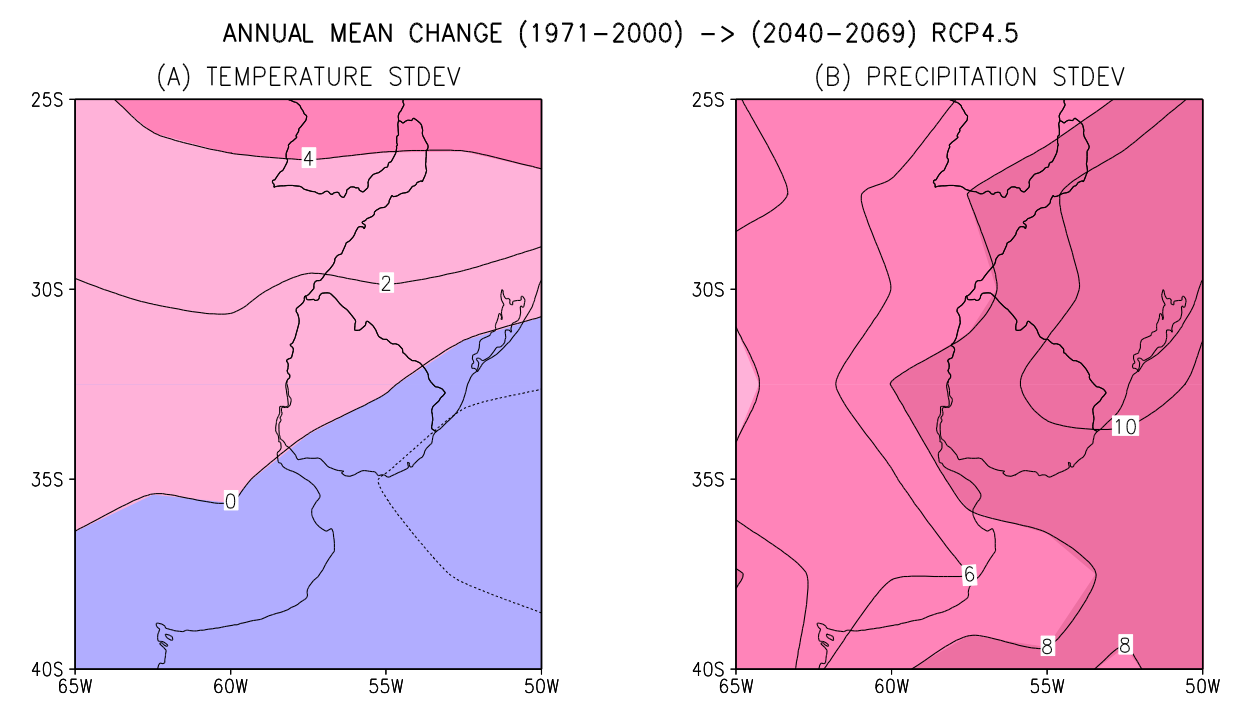

Figure 3.2: Projected changes in the standard deviation of temporal variations in (a) temperature and (b) precipitation (both in \%) in Uruguay and its adjacent areas from the period 1971-2000 to 2040-2069 under RCP4.5

In incident solar radiation and relative humidity, the multi-model mean changes are negligibly small throughout the year (Figures 3.1(c)-(d) and 3.4(c)-(d)). The inter-model uncertainty covers an interval from approximately -4 to $+4 \%$ ( -3 to +4 percentage points) for solar radiation (humidity). Wind speeds are projected to increase by about $2 \%$ in seasons other than the Southern Hemisphere winter (Figure 3.5). Moreover, according to the model simulations the proportion of easterly winds increases.

The standard deviation of temperature in Uruguay does not alter significantly (Figures 3.2(a) and 3.4(e)). This indicates that the cold and warm temperature extremes will rise approximatively at a rate that is equal to the trend in the time-mean temperature (Figure 3.4(a)).

For precipitation, changes in temporal variability are slightly larger than the corresponding changes in temporal means (Figures 3.2(b) vs. 3.1(b); Figures 3.4(f) and (b)). In accordance with this, the maximum one-day precipitation will increase, mostly so in the December-February and March-May seasons; in these seasons, the inter-model agreement on the sign of change is also quite high (Figure 3.6, left panel). Heavy precipitation events are likely to intensify in spring as well, while in winter the direction of change is ambiguous. The lengths of dry periods change fairly little in the first half of the year but are likely to increase in the Southern Hemisphere winter and spring (Figure 3.6, right panel). Note, however, that in this quantity the inter-model differences are large.

As the territory of Uruguay is relatively small, the projected climatic changes are generally fairly uniform across the country (Figures 3.1, 3.2 and 3.5). Even so, somewhat larger increases in precipitation and its temporal variability are projected for north-eastern Uruguay than elsewhere.

To summarize, the anticipated climate change in Uruguay is rather gentle compared to many other areas of the world. One reason for this is that the Southern Hemisphere is predominantly covered by oceans. The specific heat capacity of water is large, and in addition, vertical mixing acts to transfer heat deeper into the ocean. Accordingly, oceans absorb heat effectively, thus stabilizing climate. In addition, over water surfaces latent heat consumed for evaporation tends to curtail the temperature increase. 
TIME SERIES OF CHANGE FOR URUGUAY

(A) TEMPERATURE, $32.5^{\circ} \mathrm{S}, 57.5^{\circ} \mathrm{W}$

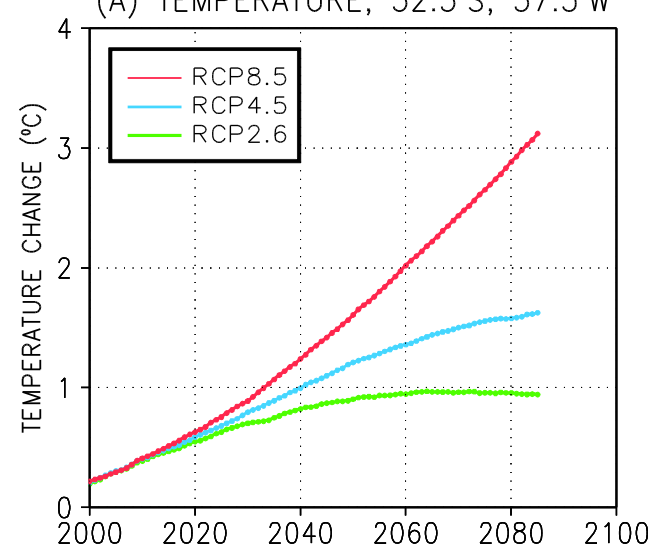

(C) SOLAR RADIATION, $32.5^{\circ} \mathrm{S}, 57.5^{\circ} \mathrm{W}$

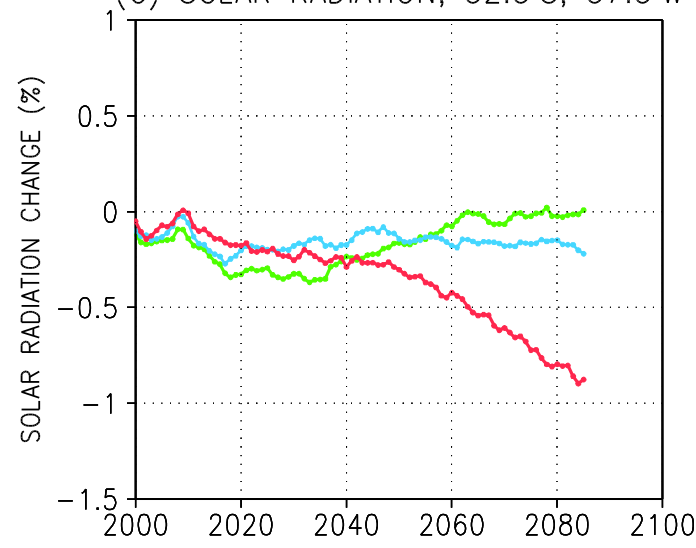

(B) PRECIPITATION, $32.5^{\circ} \mathrm{S}, 57.5^{\circ} \mathrm{W}$
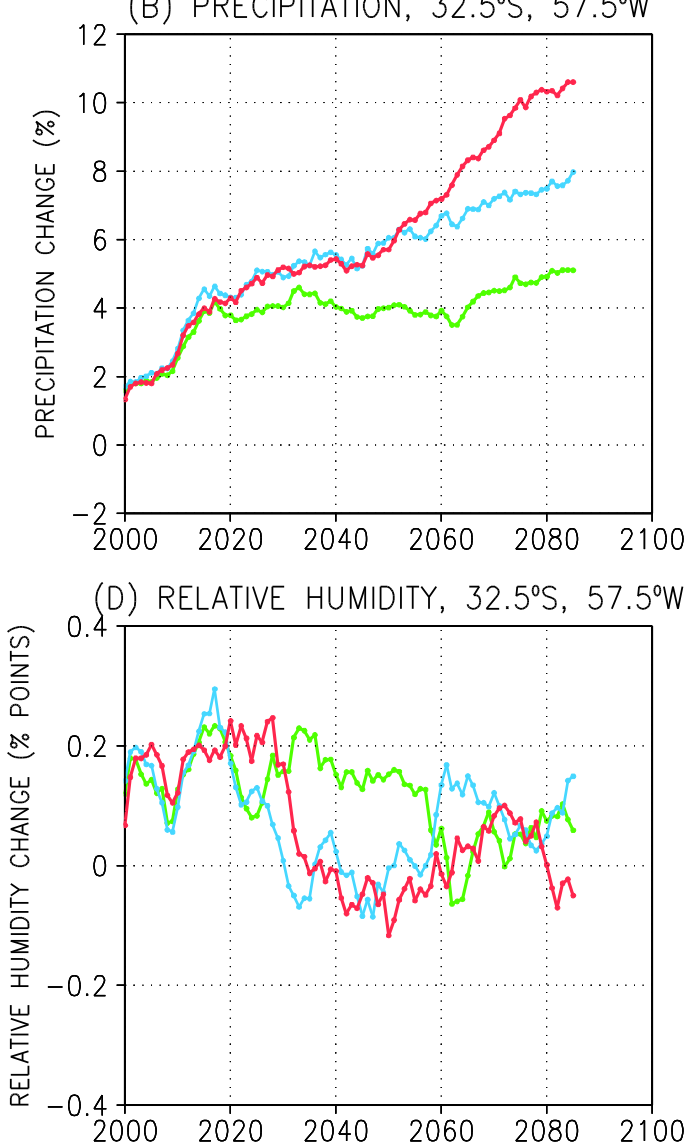

Figure 3.3: Projected annual mean changes relative to 1971-2000 in (a) mean temperature (in ${ }^{\circ} \mathrm{C}$ ), (b) precipitation (in \%), (c) incident solar radiation (in \%) and (d) relative humidity (in percentage points) at $32.5^{\circ} \mathrm{S}, 57.5^{\circ} \mathrm{W}$ (western Uruguay; the position is marked in Figure 3.1(a)). The time series are shown separately for the RCP2.6, RCP4.5 and RCP8.5 scenarios (see the legend). 
(A) TEMPERATURE, $32.5^{\circ} \mathrm{S}, 57.5^{\circ} \mathrm{W}$

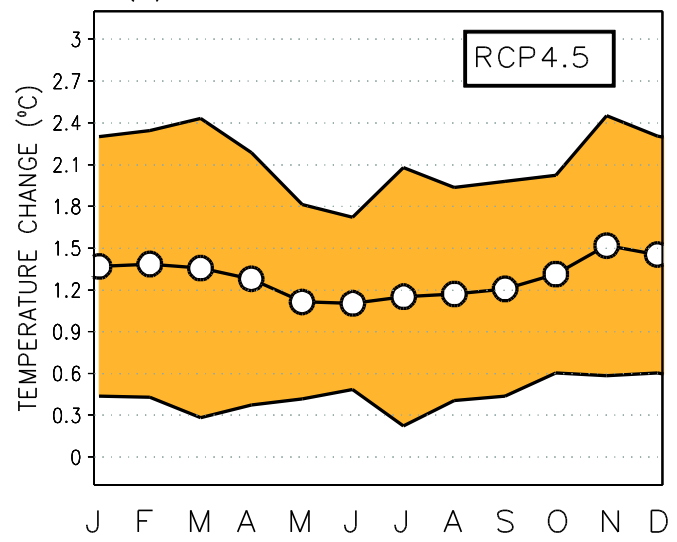

(C) SOLAR RADIATION, $32.5^{\circ} \mathrm{S}, 57.5^{\circ} \mathrm{W}$

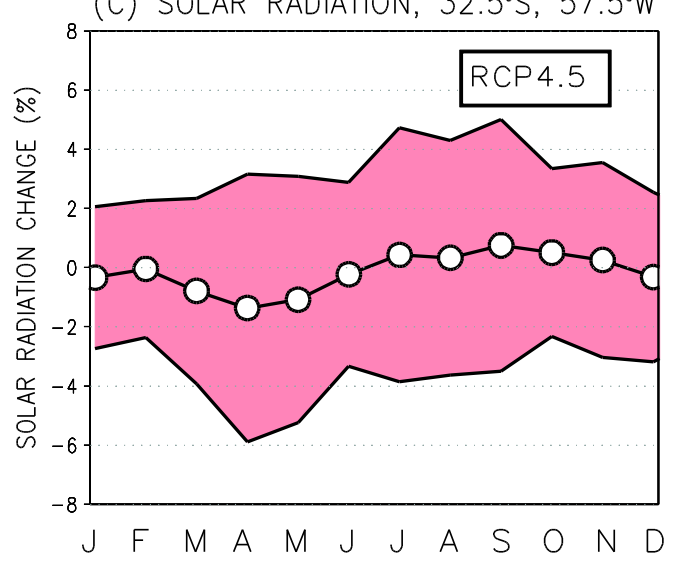

(E) TEMPERATURE STDEV, $32.5^{\circ} \mathrm{S}, 57.5^{\circ} \mathrm{W}$

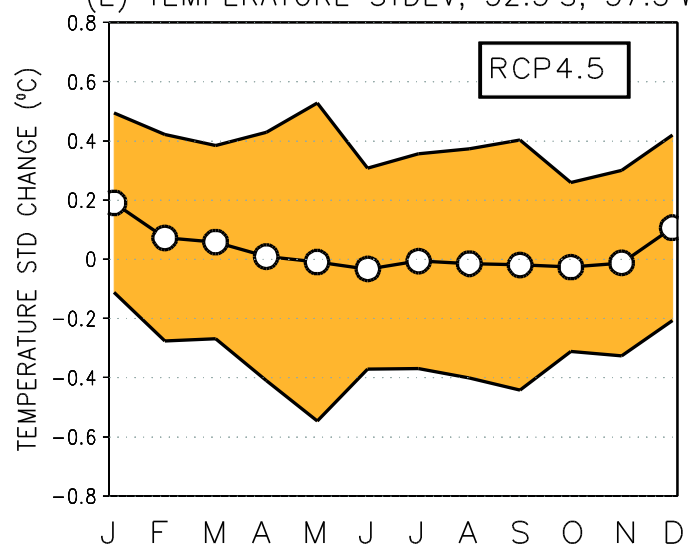

(B) PRECIPITATION, $32.5^{\circ} \mathrm{S}, 57.5^{\circ} \mathrm{W}$

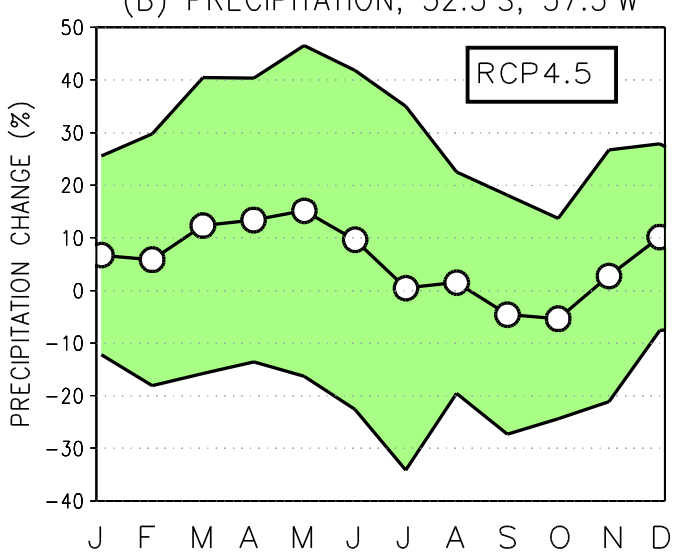

(D) RELATIVE HUMIDITY, $32.5^{\circ} \mathrm{S}, 57.5^{\circ} \mathrm{W}$

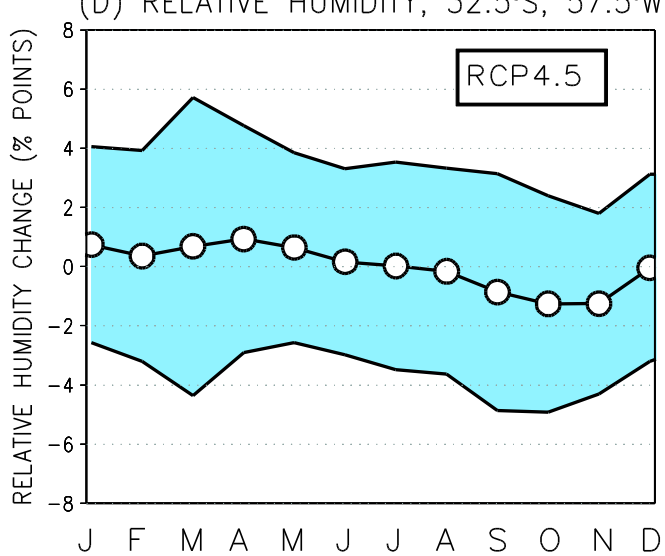

(F) PRECIPITATION STDEV, $32.5^{\circ} \mathrm{S}, 57.5^{\circ} \mathrm{W}$

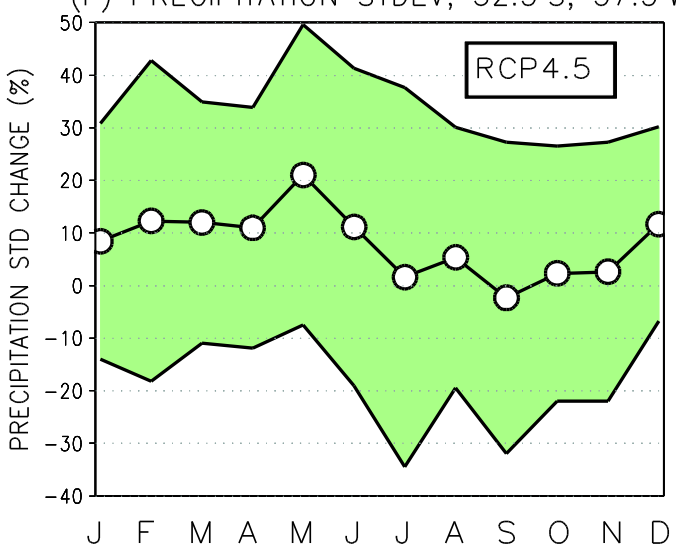

Figure 3.4: Projected monthly changes in (a) the mean temperature $\left(\right.$ in $\left.{ }^{\circ} C\right)$, (b) precipitation (in \%), (c) incident solar radiation (in \%) and $(d)$ relative humidity (in percentage points) at $32.5^{\circ} \mathrm{S}, 57.5^{\circ} \mathrm{W}$ (western Uruguay; the position is marked in Figure $3.1(a))$ under RCP4.5 for the period 2040-2069, relative to 1971-2000. Corresponding changes in the temporal standard deviation of daily-mean temperature $\left(\right.$ in ${ }^{\circ} \mathrm{C}$ ) and precipitation (in \%) are shown in panels (e) and (f). The multi-model mean projections for individual calendar months $(J=$ January,..., $D=$ December $)$ are denoted by open circles. Shading shows the $90 \%$ uncertainty intervals for the projection. 
SEASONAL CHANGES (\%) IN GEOSTROPHIC WIND SPEED (1971-2000) -> (2040-2069)
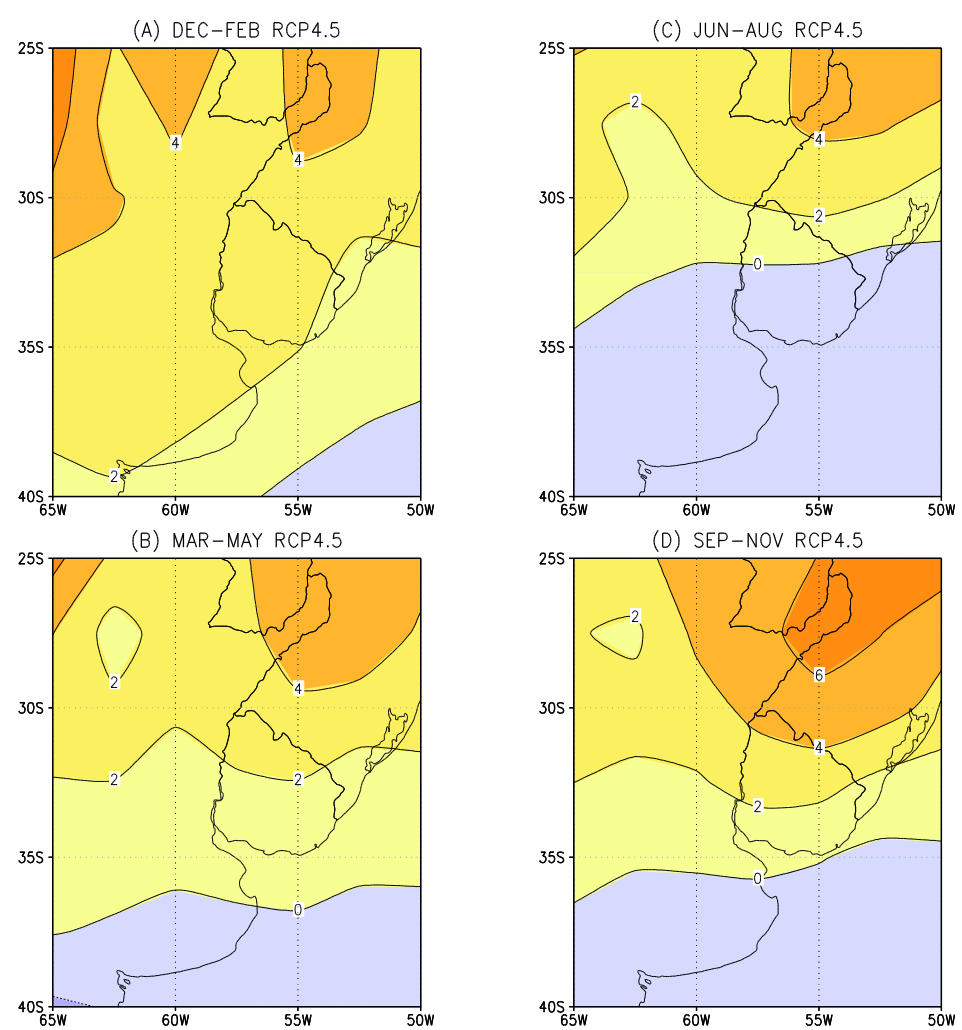

Figure 3.5: Projected seasonal changes (in percent) in the time-mean geostrophic wind speed in Uruguay from 1971-2000 to 2040-2069 under RCP4.5 in (a) DecemberFebruary, (b) March-May, (c) June-August and (d) September-November. The contour interval is $2 \%$.
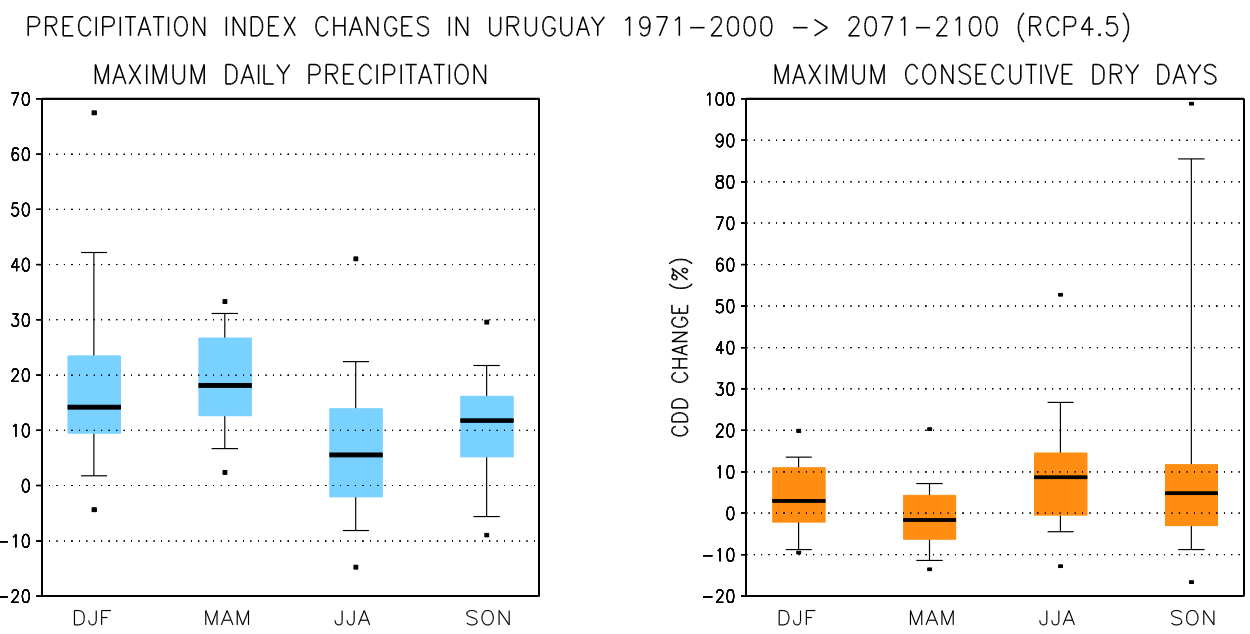

Figure 3.6: Model-derived seasonal changes (in percent) in the maximum one-day precipitation Rld (left panel) and the maximum number of consecutive dry days CDD (with precipitation < $1 \mathrm{~mm} /$ day; right panel) at $32.5^{\circ} \mathrm{S}, 57.5^{\circ} \mathrm{W}$ (western Uruguay; the position is marked in Figure 3.1(a)) under RCP4.5 for the period 2071-2100, relative to 19712000. The coloured bars show the 25th to 75th percentile intervals of the change derived from the responses of 21 models. The corresponding 10th to 90th percentile intervals are depicted by whiskers and the minimum and maximum responses among the models by black dots. The black lines within the bars stand for the multi-model medians. The probability distributions are given separately for four seasons: December-February (DJF), March-May (MAM), June-August (JJA) and September-November (SON). 


\subsection{Overview of climate change impacts in Uruguay}

Climate change is predicted to have various impacts in Latin America. The impacts vary from location to location. Heat extremes will increase, sea level will continue to rise and the volume of tropical mountain glaciers continues to decrease. Probability of coral reef bleaching is increasing. There is a risk of Amazon rainforest degradation (Reyer et al., 2017b). At some regions, climate change may influence negatively on agricultural yields but, on the other hand, the change may increase, e.g., potential for higher rice yields (Reyer et al., 2017b). El Niño and La Niña ${ }^{4}$ events influence a lot on the weather in Latin America. In Argentina, Paraguay and Uruguay, rainfall is typically increasing during El Niño. La Niña indicates typically cooler and dryer than normal weather. The influence of climate change on the frequency of El Niño and La Niña events is still an open question. However, there are studies indicating that an extreme El Niño may become more frequent (e.g. Wang et al., 2017).

In Uruguay, the most harmful climate phenomena are related to events such as droughts, floods, frosts, heat waves, hail and squall lines. The impact of climate change on agriculture can vary depending on the crop. For example, for winter crops, like barley and wheat an increase of temperature can be harmful whereas for summer crops, like rice, warming can be positive. Increased temperature may benefit grassland production, but precipitation deficiencies or increased variability is harmful. This is why the potential increase in climate variability, e.g., in the frequency of El Niño and La Niña events is important.

Uruguayan coastal resources are vulnerable to global climate change due to the rising sea level. Under the RCP2.6 scenario, the sea level would rise on Atlantic Coast of Latin America around 20 to 50 centimeters until the end of this century. Under RCP8.5, the sealevel rise would be 50 to 90 centimeters (Reyer et al., 2017b); note, however, that these estimates will be updated by the IPCC. Hareau et al. (1999) estimated that the largest economic risk caused by sea level rise would be experienced in urbanized areas like the Maldonado-Punta del Este resort and in Montevideo. Sea level rise may also cause flooding and salinization of lowlands and reduce course of the water flows that discharge along the coast. Especially the Santa Lucía river is vulnerable as it is the source of drinking water for Montevideo (Hareau et al., 1999).

Climate change adaptation and mitigation measures are actively implemented in Uruguay. The Fourth National Communication was prepared by the Ministry of Housing, Land-Use Planning and Environment (MVOTMA) within the framework of the National Climate Change Response System (SNRCC). SNRCC and the National Environment System coordinate climate change and environment actions. SNRCC has also developed a National Climate Change Policy (PNCC) which provides a long-term strategic framework to integrate and strengthen the approach to mitigation and adaptation. This policy identifies strategic priority actions and specific institutional and capacity building measures to create an enabling environment for adaptation planning. PNCC was adopted by the National Environment Cabinet in April 2017. In PNCC, nine key adaptation strategic areas and objectives were defined (Table 1) that provided a good basis for the future activities to be taken.

\footnotetext{
${ }^{4}$ El Niño Southern Oscillation (ENSO) is a natural phenomenon. Ocean and atmospheric conditions in the tropical Pacific Ocean fluctuate between El Niño (warm conditions) and a drop in temperature (La Niña). The fluctuations are rather irregular, appearing approximately every three to six years. Intensive phase of each event may last for about a year.
} 
Table 1. The key climate change adaptation strategic areas and objectives in Uruguay (National Climate Change Policy, 2017).

1. Generate, obtain and systematize relevant, integrated, useful and accessible information for decision-making

2. Strengthen the risk management of climate-related disasters at national, departmental and local levels

3. Promote the development of cities, urban settlements and infrastructure that are sustainable and resilient to climate change.

4. Promote the resilience and adaptation of the society to climate change, and extreme weather and climate events, with an emphasis on the most vulnerable social and climate groups

5. Promote the conservation, recovery and restoration of natural ecosystems, and the provision of ecosystem goods and services

6. Reduce vulnerability in riverine, coastal and marine areas, through adaptation actions based on ecosystems

7. Promote the consideration of climate change and variability in the integrated management of water resources to ensure their availability and quality

8. Promote systems of agricultural production of greater capacity of adaptation and resilience to climate change

9. Promote the integration of climate change and variability consideration in cross-cutting planning and management of tourism activities

To summarize: In addition to sea-level rise, the largest risks of climate change in Uruguay are related to possible hazards such as droughts and floods, heatwaves, hails, storms and tornados. The El Niño - Southern Oscillation phenomenon (ENSO) further increases inter-annual variability with higher precipitation during the El Niño years and more severe droughts during the La Niña years. If climate change influences the frequency and intensity of these phenomena, it may cause new challenges to the Uruguayn society.

According to the Global Forest Watch (2019), the tree cover loss in Uruguay between 2001 and 2017 was 327,000 ha whereas the tree cover gain between 2001 and 2012 was 499,000 ha (Figure 3.7; Hansen et al., 2013). The tree covered area has thus increased by about 170,000 ha during the about 15 -year period. If the development continues, it also contributes to Uruguay's greenhouse gas balance in a positive way, i.e., the role of forests as a carbon sink increases. 


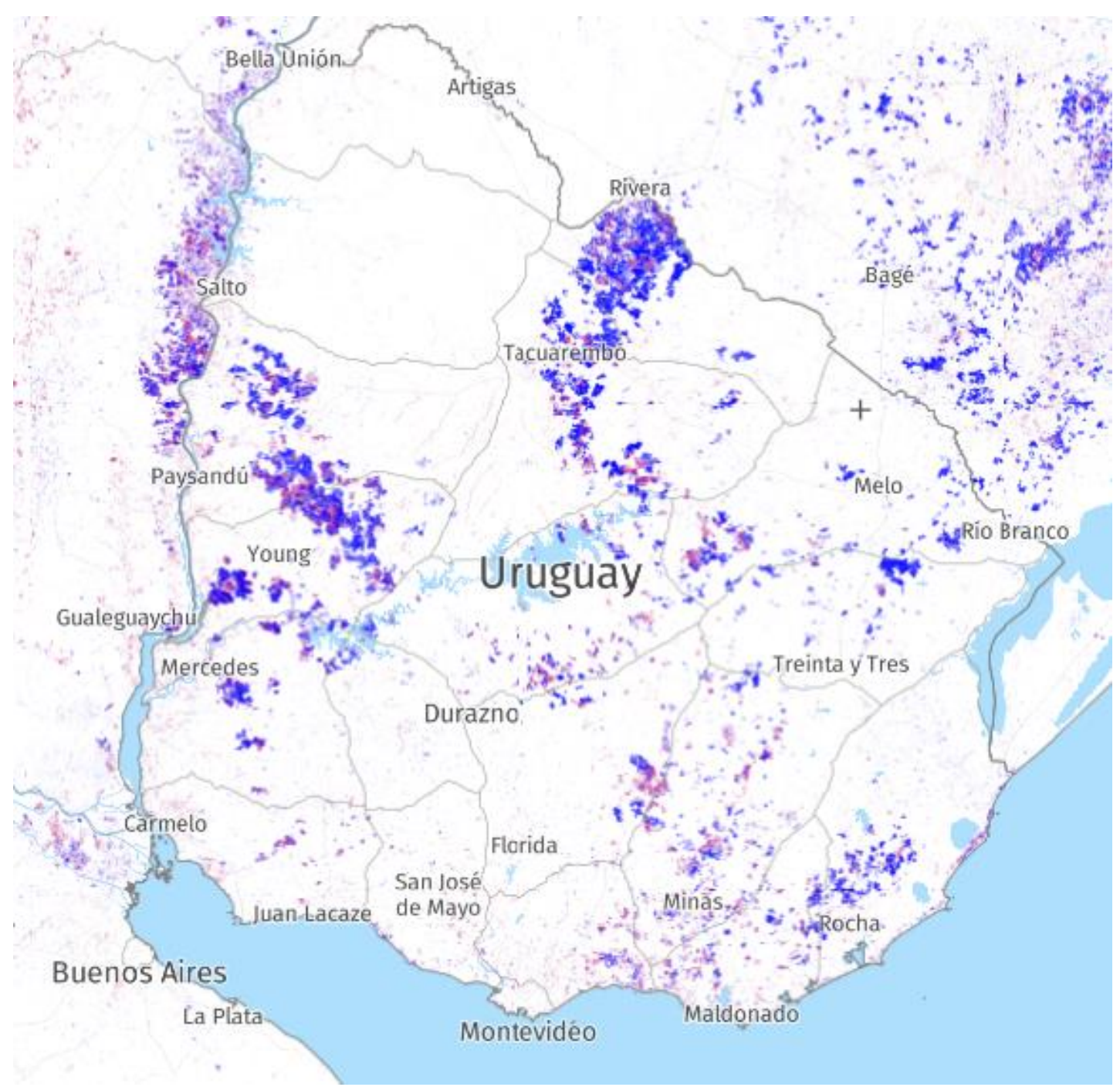

Figure 3.7: Tree cover change in Uruguay. Red colour indicates areas of loss and blue those of gain. Source: Hansen/UMD/Google/USGS/NASA, accessed through Global Forest Watch. 


\section{Climate change and impacts in China}

\subsection{Projected change of climate in China}

According to the multi-model mean projection, annual mean temperature and precipitation total are both anticipated to increase over the entire territory of China, the changes being strongest in the western and northern provinces (Figure 4.1(a)-(b)). Solar radiation increases by $2-4 \%$ in wide areas of eastern China (Figure 4.1(c)). This phenomenon can at least partially be attributed to cleaning of air due to a reduction of sulphur dioxide and other emissions producing aerosol particles. Changes in relative humidity are virtually negligible (Figure 4.1(d)).

ANNUAL MEAN CHANGE (1971-2000) -> (2040-2069) RCP4.5

(A) TEMPERATURE

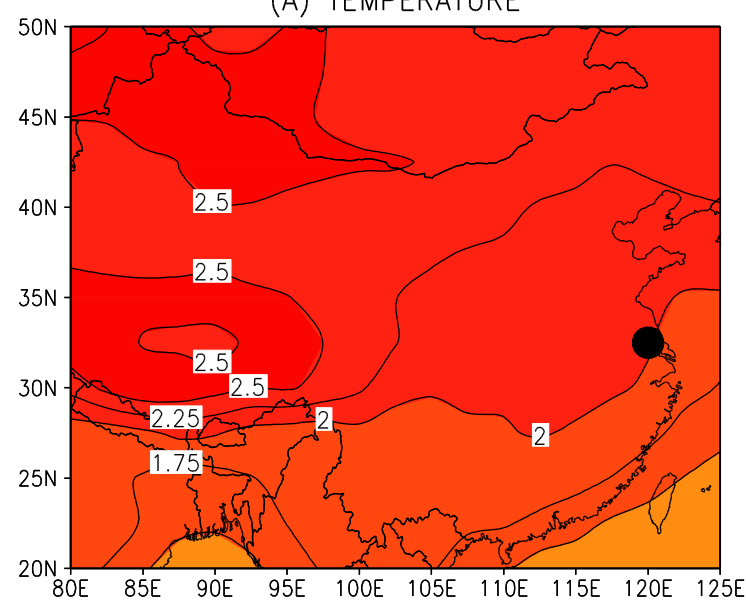

(C) SOLAR RADIATION

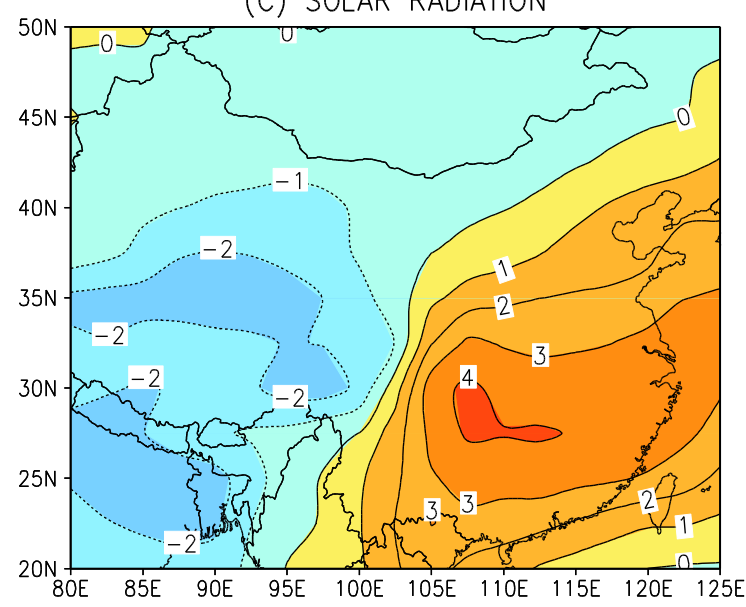

(B) PRECIPITATION

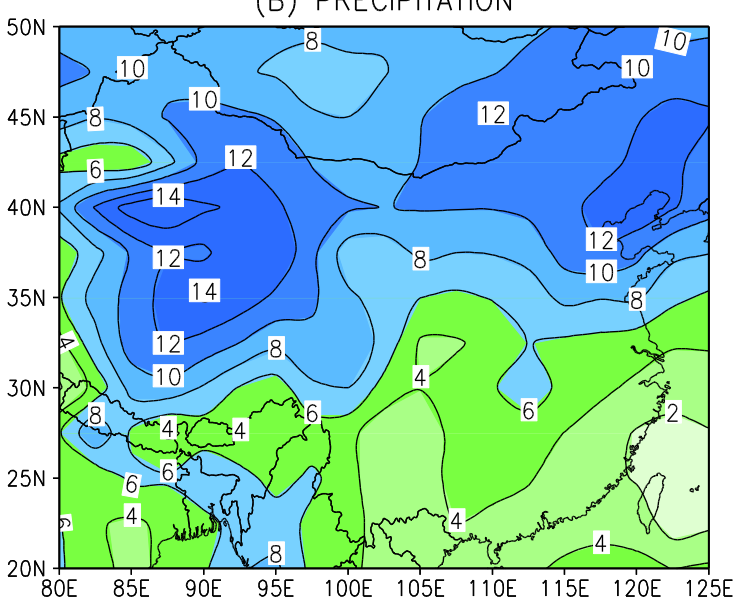

(D) RELATIVE HUMIDITY

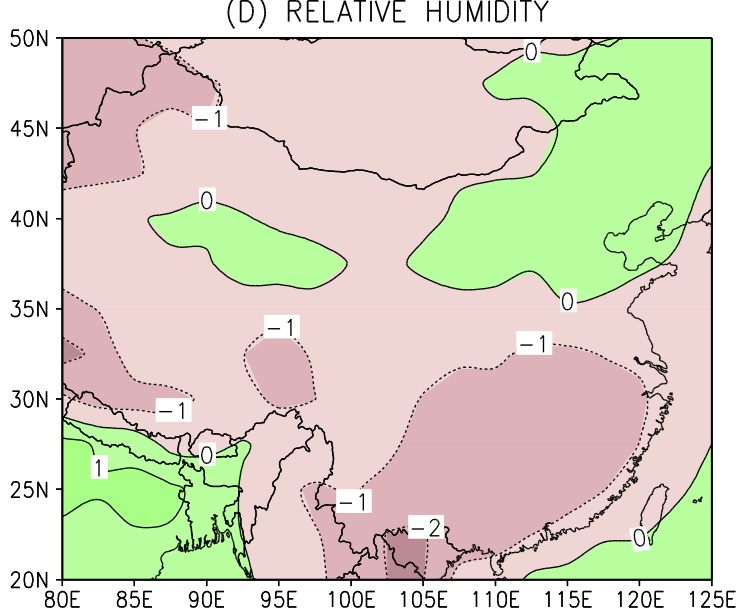

Figure 4.1: Projected changes in annual mean (a) temperature $\left(\right.$ in $\left.{ }^{\circ} \mathrm{C}\right),(b)$ precipitation (in \%), (c) incident solar radiation (in \%) and $(d)$ relative humidity (in percentage points) in China from the period 1971-2000 to 2040-2069 under RCP4.5. The position of the grid point $32.5^{\circ} \mathrm{N}, 120^{\circ} \mathrm{E}$ examined in the more detailed analyses is marked by a dot in panel (a). 
ANNUAL MEAN CHANGE $(1971-2000)->(2040-2069)$ RCP4.5

(A) TEMPERATURE STDEV

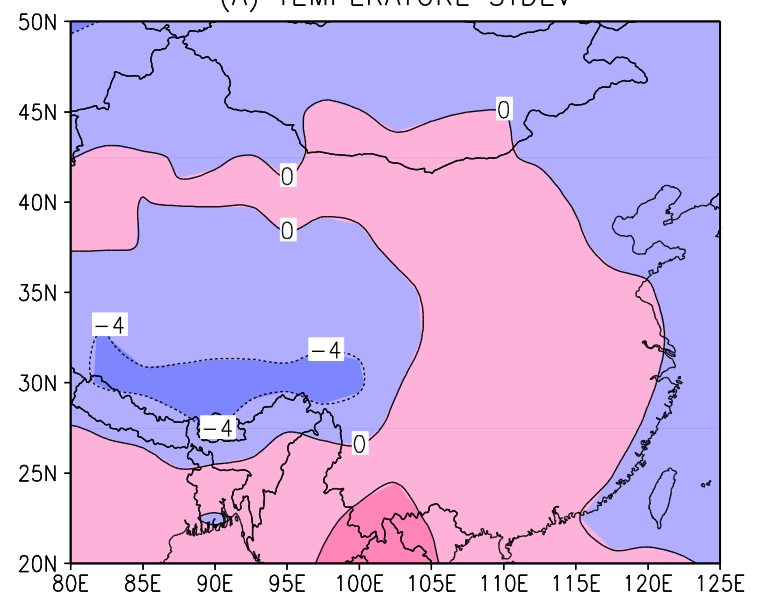

(B) PRECIPITATION STDEV

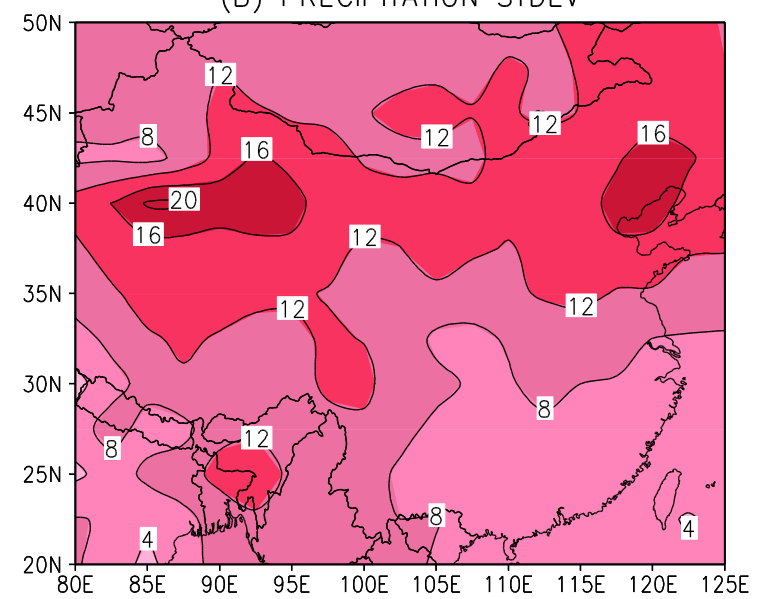

Figure 4.2: Projected changes in the standard deviation of temporal variations in $(a)$ temperature and (b) precipitation (both in \%) in China from the period 1971-2000 to 2040-2069 under RCP4.5.

TIME SERIES OF CHANGE FOR EASTERN CHINA

(A) TEMPERATURE, $32.5^{\circ} \mathrm{N}, 120^{\circ} \mathrm{E}$

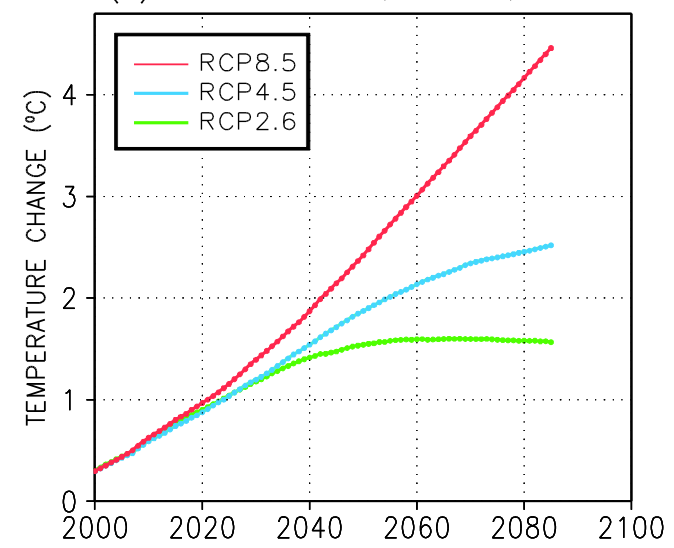

(C) SOLAR RADIATION, $32.5^{\circ} \mathrm{N}, 120^{\circ} \mathrm{E}$

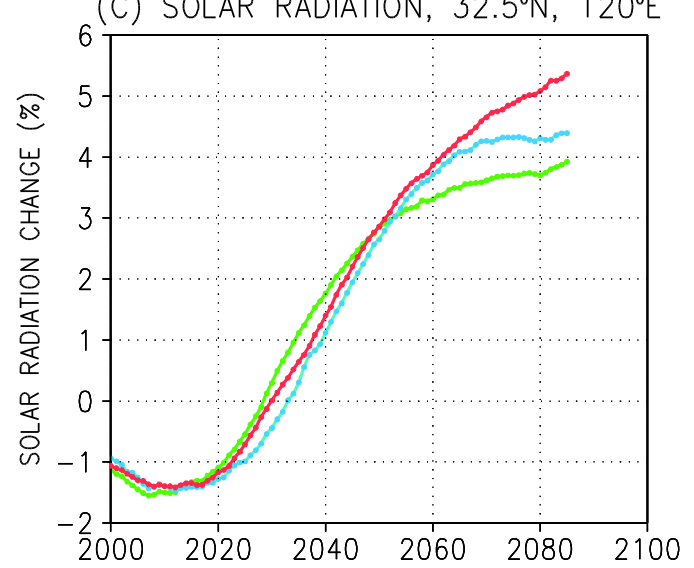

(B) PRECIPITATION, $32.5^{\circ} \mathrm{N}, 120^{\circ} \mathrm{E}$

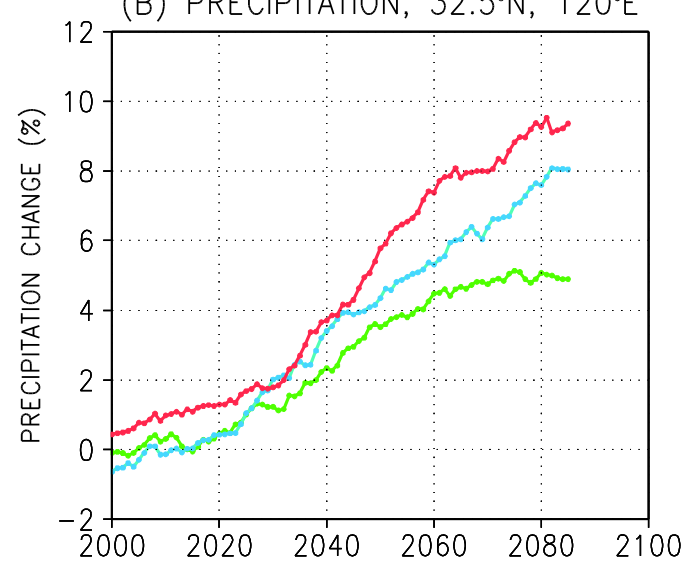

(D) RELATIVE HUMIDITY, $32.5^{\circ} \mathrm{N}, 120^{\circ} \mathrm{E}$

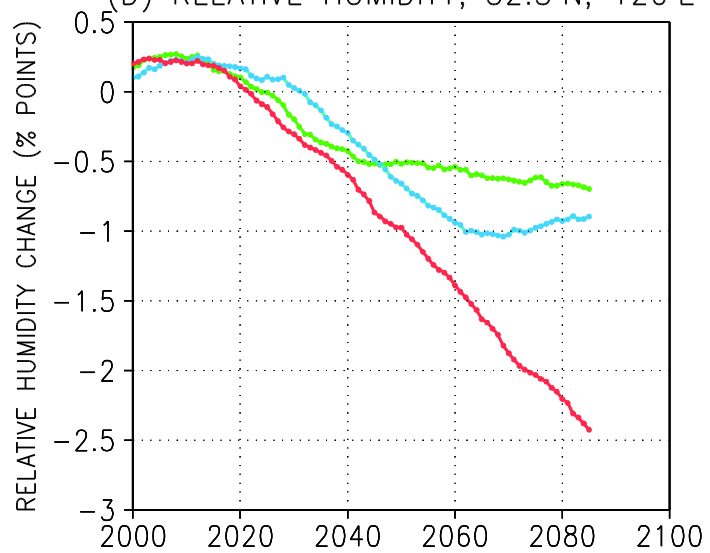

Figure 4.3: Projected annual mean changes relative to 1971-2000 in (a) mean temperature (in ${ }^{\circ} \mathrm{C}$ ), (b) precipitation (in \%), (c) incident solar radiation (in \%) and (d) relative humidity (in percentage points) at $32.5^{\circ} \mathrm{N}, 120^{\circ} \mathrm{E}$ (eastern China; the position is marked in Figure 4.1(a)). The time series are shown separately for the RCP2.6, RCP4.5 and RCP8.5 scenarios (see the legend). 
Focusing on the target point located near the eastern coast of China (the position is given in Figure 4.1(a)), the best estimate for the annual-mean temperature increase is about $2^{\circ} \mathrm{C}$ and for the precipitation increase $5 \%$ (by the period 2040-2069 under RCP4.5; see Figure 4.3 (a)-(b)).

SEASONAL CYCLE OF THE CHANGE IN EASTERN CHINA

(A) TEMPERATURE, $32.5^{\circ} \mathrm{N}, 120^{\circ} \mathrm{E}$

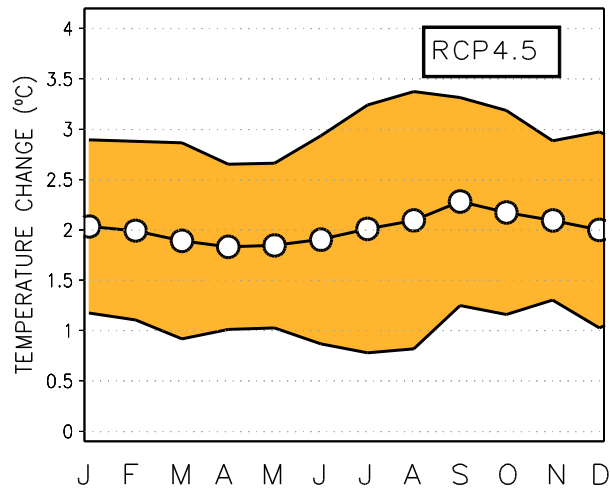

(C) SOLAR RADIATION, $32.5^{\circ} \mathrm{N}, 120^{\circ} \mathrm{E}$

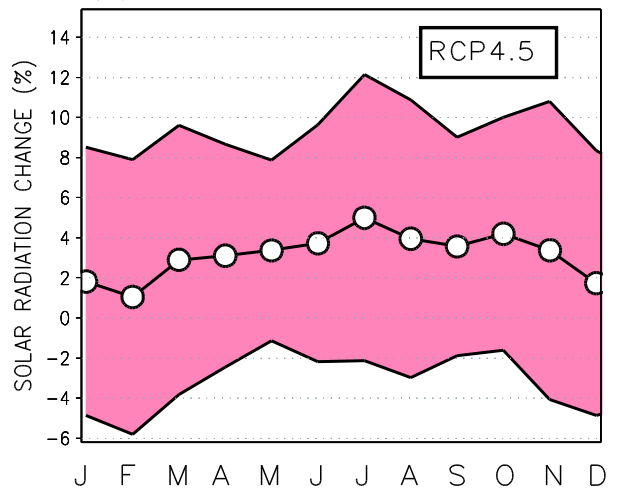

(E) TEMPERATURE STDEV, $32.5^{\circ} \mathrm{N}, 120^{\circ} \mathrm{E}$

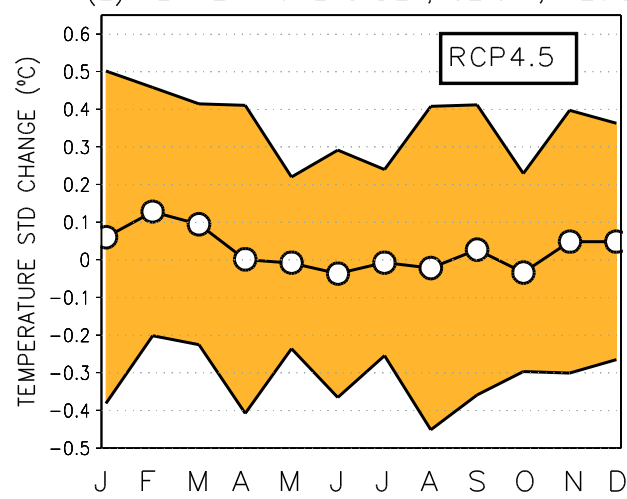

(B) PRECIPITATION, $32.5^{\circ} \mathrm{N}, 120^{\circ} \mathrm{E}$

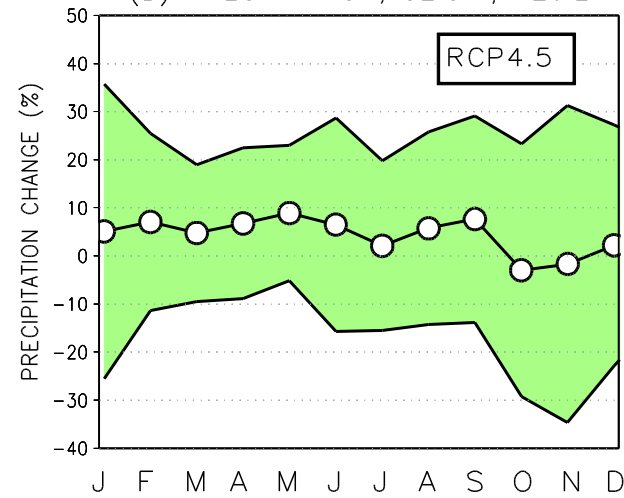

(D) RELATIVE HUMIDITY, $32.5^{\circ} \mathrm{N}, 120^{\circ} \mathrm{E}$

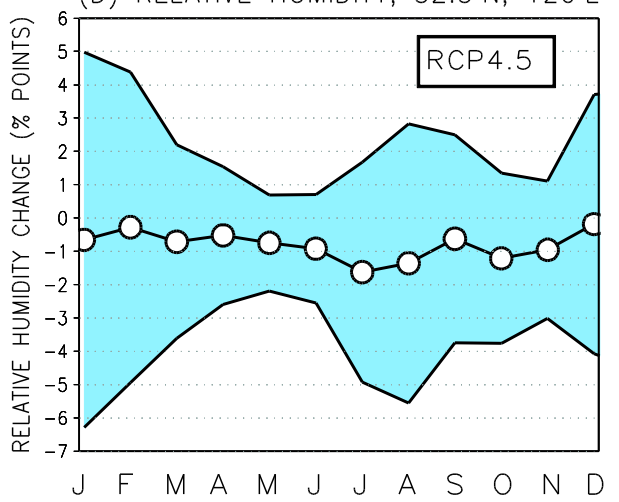

(F) PRECIPITATION STDEV, $32.5^{\circ} \mathrm{N}, 120^{\circ} \mathrm{E}$

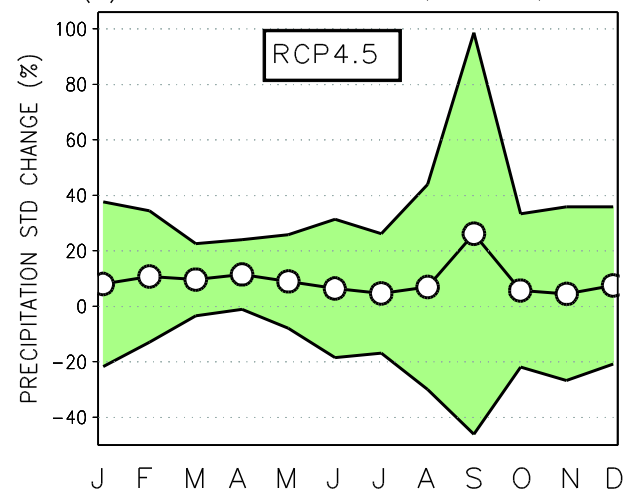

Figure 4.4: Projected monthly changes in (a) the mean temperature (in ${ }^{\circ} \mathrm{C}$ ), (b) precipitation (in \%), (c) incident solar radiation (in \%) and (d) relative humidity (in percentage points) at $32.5^{\circ} \mathrm{N}, 120^{\circ} \mathrm{E}$ (eastern China; the position is marked in Figure 4.1(a)) under RCP4.5 for the period 2040-2069, relative to 1971-2000. Corresponding changes in the temporal standard deviation of daily-mean temperature (in ${ }^{\circ} \mathrm{C}$ ) and precipitation (in \%) are shown in panels (e) and (f). The multi-model mean projections for individual calendar months $(J=$ January,..., $D=$ December $)$ are denoted by open circles. Shading shows the $90 \%$ uncertainty intervals for the projection.

Compared to the other seasons, warming may be slightly stronger in late summer and early autumn; however, considering the inter-model scatter, it is likely that the temperature 
increase falls between about 1 and $3^{\circ} \mathrm{C}$ throughout the year (Figure 4.4(a)). Precipitation is most likely to increase by $0-10 \%$ in all seasons except late autumn, but the uncertainty interval is wide and the sign of change remains uncertain (Figure 4.4(b)). The sign of change cannot either be established for solar radiation and relative humidity (Figures 4.4(c)-(d)), even though it is more likely that solar radiation increases than decreases. Wind speeds may slightly increase in summer and decrease in winter; according to the multimodel mean, by about $2 \%$ (Figure 4.5).

The standard deviation of temperature presumably does not change notably in eastern China (Figure 4.2(a)), even though there is some modelling uncertainty in this estimate as well (Figure 4.4(e)). Consequently, the temporal variations of temperature are not likely to amplify or attenuate significantly, and the extremely low and high temperatures will rise approximately at a similar rate as the mean temperature (Figures 4.1 (a) and 4.4(a)).

SEASONAL CHANGES (\%) IN GEOSTROPHIC WIND SPEED (1971-2000) $->(2040-2069)$
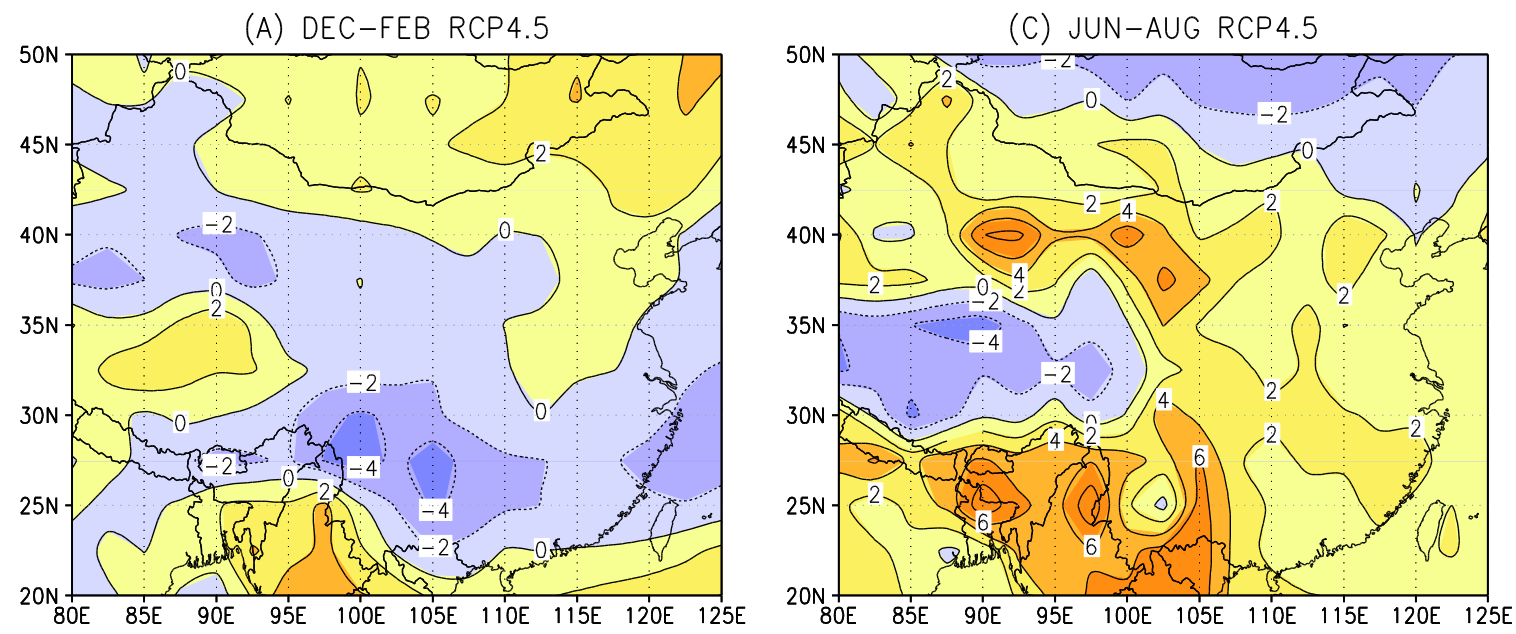

(B) MAR-MAY RCP4.5

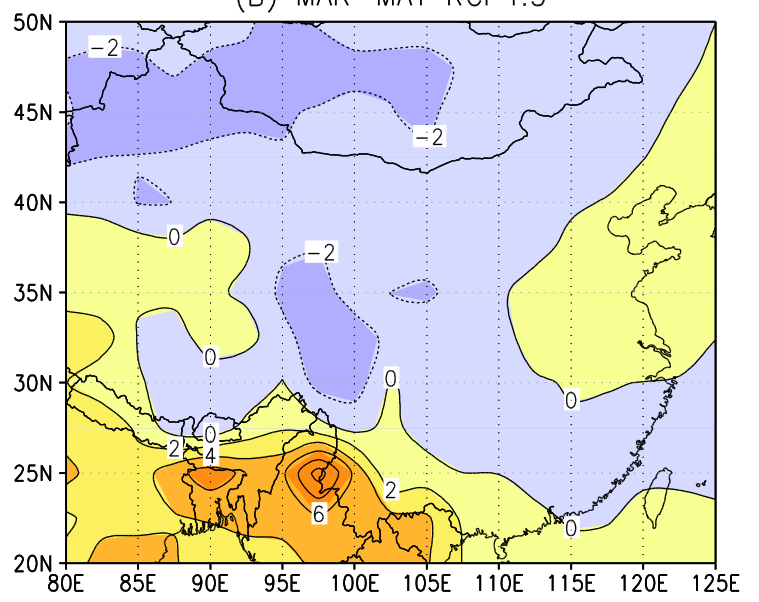

(D) SEP-NOV RCP 4.5

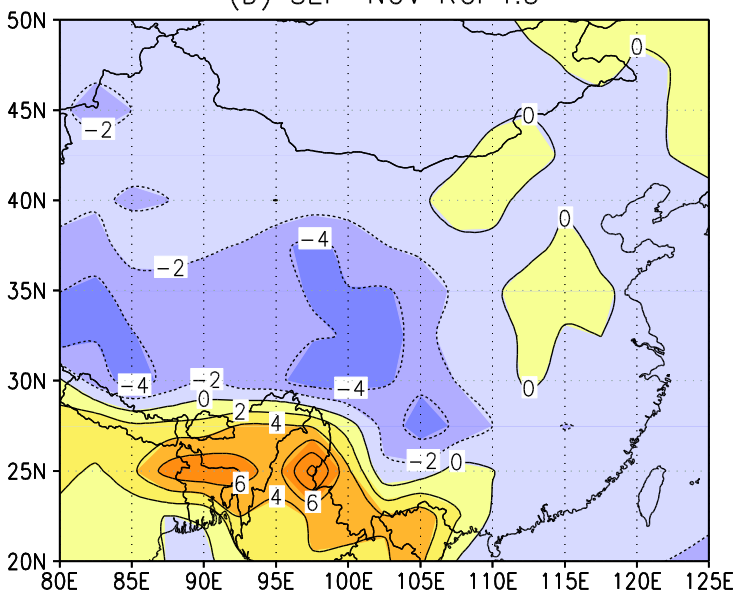

Figure 4.5: Projected seasonal changes (in percent) in the time-mean geostrophic wind speed in China from 1971-2000 to 2040-2069 under RCP4.5 in (a) December-February, (b) March-May, (c) June-August and (d) September-November. The contour interval is 2 $\%$.

The temporal variability of precipitation is more likely to increase than decrease (Figures 4.2(b) and 4.4(f)). In conjunction with increasing time-mean precipitation, this indicates that extreme precipitation events will become more intense. According to the multi-model median, the maximum one-day precipitation totals would increase by $10-15$ $\%$, depending on the season (Figure 4.6, left panel). The inter-model agreement on the intensification is largest in spring and summer when more than $90 \%$ of all the models inspected project stronger maximum 1-day precipitation for the future. As another 
indication of the more extreme precipitation climate in the future, dry periods are expected to lengthen in all seasons apart from summer (Figure 4.6(right panel)). Nonetheless, for this quantity inter-model agreement on the direction of change is lower than for the maximum one-day precipitation.

In the catchment area of the Yangtze river, both the mean temperature and annual precipitation are likely to increase moderately. Accordingly, the increasing supply of water by precipitation is partially compensated by increasing evaporation of water due to higher temperatures, resulting in fairly modest changes in the time-mean discharge in the Yangtze river. Even so, as strong precipitation events intensify and, probably, dry periods between them simultaneously lengthen, temporal variations in the discharge evidently increase. This topic will be discussed in the next subsection.

PRECIPITATION INDEX CHANGES IN EASTERN CHINA 1971-2000 -> 2071-2100 (RCP4.5)
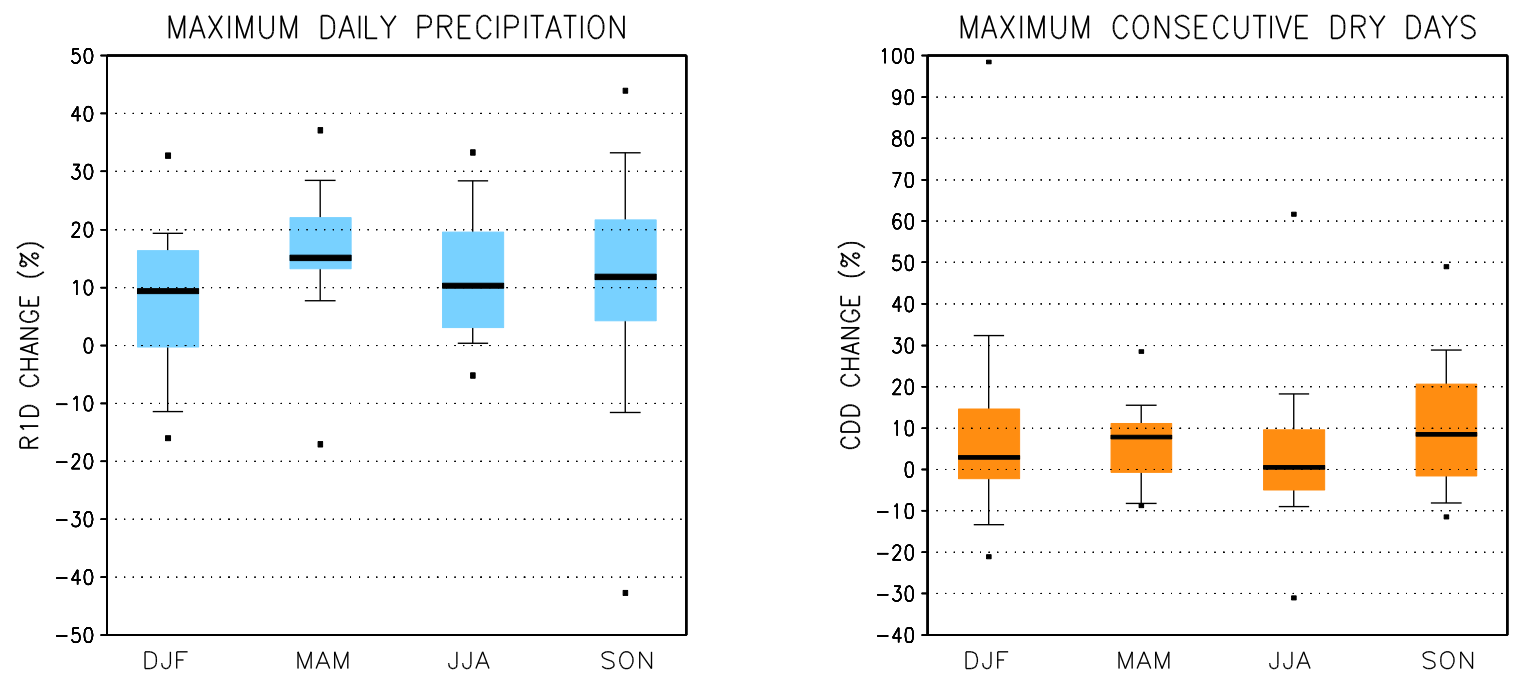

Figure 4.6: Model-derived seasonal changes (in percent) in the maximum one-day precipitation Rld (left panel) and the maximum number of consecutive dry days CDD (with precipitation $<1 \mathrm{~mm} /$ day; right panel) at $32.5^{\circ} \mathrm{N}, 120^{\circ} \mathrm{E}$ (eastern China; the position is marked in Figure 4.1(a)) under RCP4.5 for the period 2071-2100, relative to 1971-2000. The coloured bars show the 25th to 75th percentile intervals of the change derived from the responses of 21 models. The corresponding 10th to 90th percentile intervals are depicted by whiskers and the minimum and maximum responses among the models by black dots. The black lines within the bars stand for the multi-model medians. The probability distributions are given separately for four seasons: December-February (DJF), March-May (MAM), June-August (JJA) and September-November (SON).

\subsection{Impacts on the Yangtze River hydrology}

The Yangtze River is 6,380 km long and thus the longest river in Asia and the third-longest in the world (Figure 4.7). It is the sixth-largest river by discharge volume in the world. It drains one-fifth of the land area of China, and the river basin is the home for nearly onethird of the population of the country. According to the observations, the annual streamflow at Datong station located near the tidal limit of the river has been slightly increasing during the period 1960-2000 (Figure 4.8). The glaciers in the source region of the Yangtze River are shrinking. This leads to an increase of water resources over the short term, but the long-run impacts of melting glaciers can be negative and decline water resources (e.g. Liu et al., 2009; Shen et al., 2009; Piao et al., 2010). 


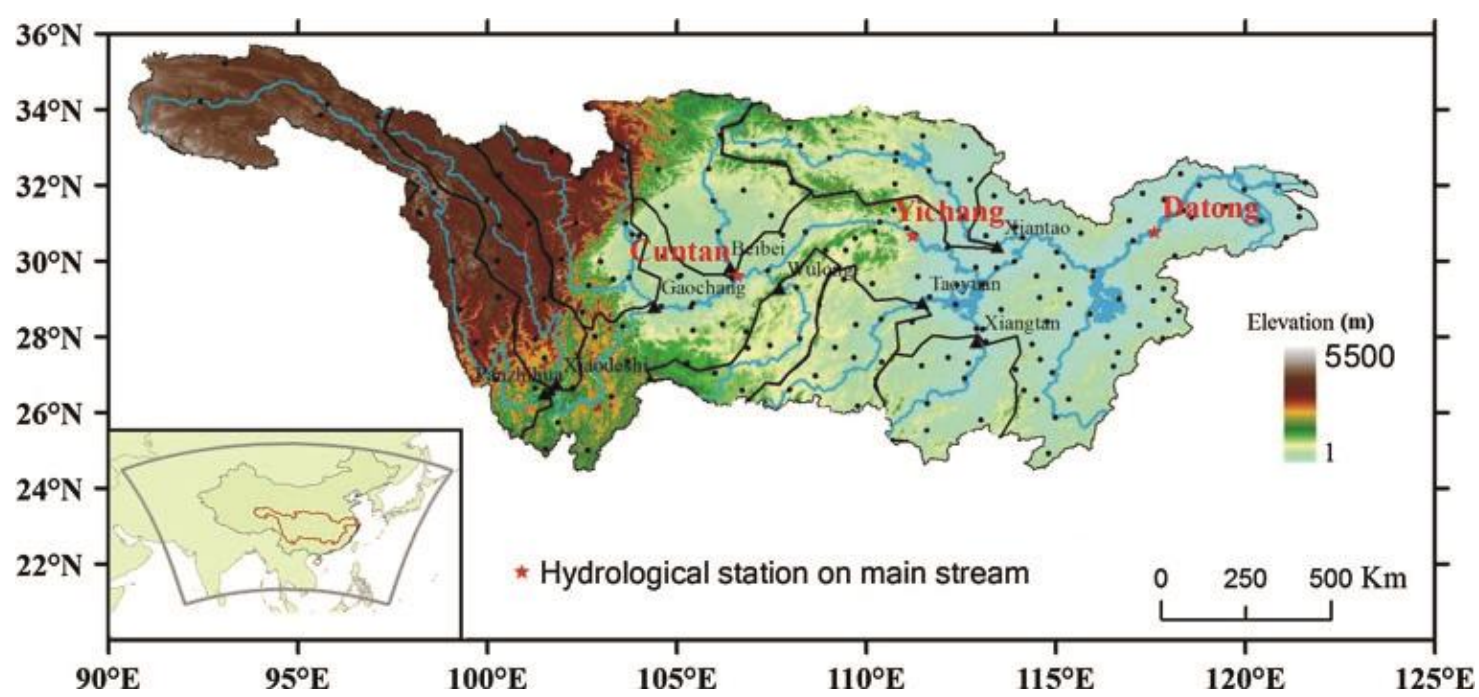

Figure 4.7: Map of the Yangtze River basin (edited from Gu et al., 2015).

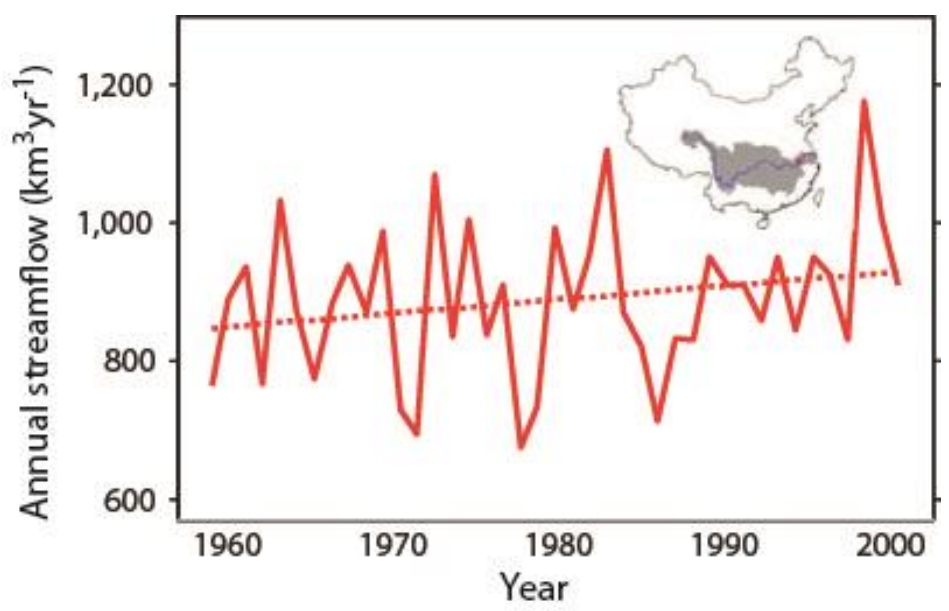

Figure 4.8: Annual runoff at Yangtze River at the Datong station during 1960-2000 (Piao et al. 2010).

Precipitation is projected to increase during the coming decades (Figures 4.1, 4.3 and 4.4), accompanied with an increase of the variability of precipitation (Figure 4.2). A number of studies dealing with the impact of climate change on the hydrological regime of the Yangtze River has been published, and these studies indicate a general increase in the annual streamflow at the Yangtze River. The increased variability of rainfall means more intense short-period rainfall events and maximum stream flows. This can increase flooding events (Wang \& Zhang, 2011; Gu et al., 2015; Yu et al., 2018; Gu et al., 2018). 
In Figure 4.9 is given, as an example, one study (Yu et al., 2018) on how monthly discharges could change at the Datong station. According to this study, in the 2080s the warm season discharge would be larger and the cold season discharge smaller, compared with the 1970-1999 period. However, the inter-model variability is large. As well, the study of $\mathrm{Gu}$ et al. (2015) indicates that discharge during the dry winter season may decrease.
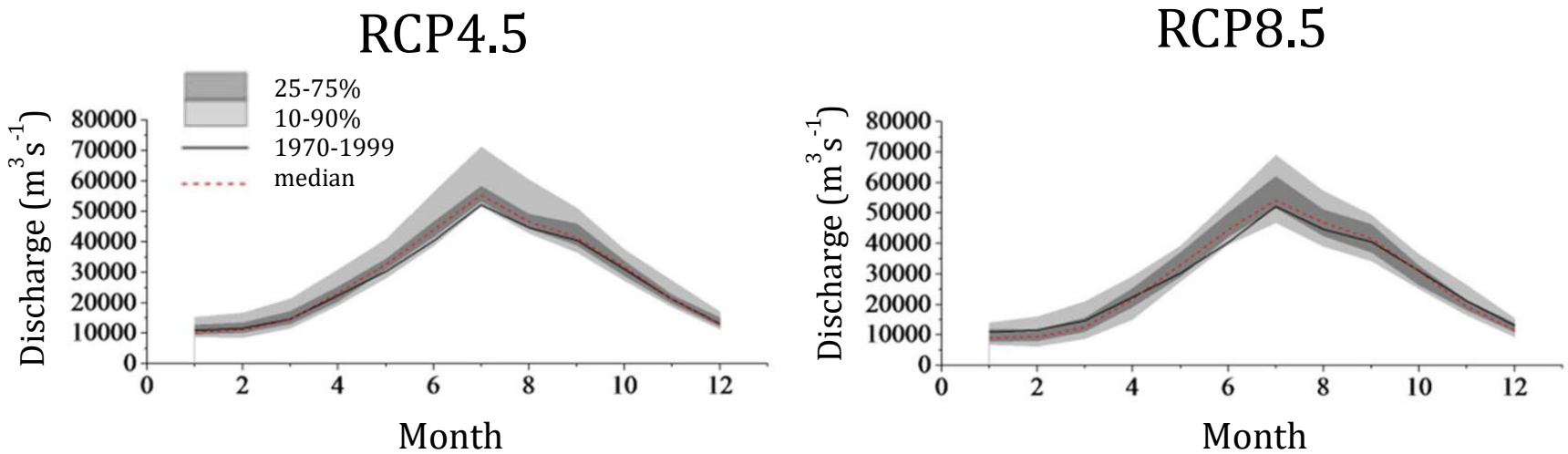

Figure 4.9: An estimate of the current and projected future monthly discharge in the 2080s at Datong station for the RCP4.5 (left panels) and RCP8.5 (right panels) scenarios based on 27 global climate models (GCMs). The red dotted line indicates the median of the model run results and continuous dark grey line is the baseline used in the study. Dark and light grey shaded areas indicate where $50 \%$ and $80 \%$ of model runs fall, respectively. The figure is edited from Yu et al. (2018).

Besides changes in rainfall patterns and glacial melting, the other factors influencing the hydrological conditions near the Yangtze River delta are the erosion caused by the sediment starvation and the sea level rise. River damming and soil conservation decrease sediment discharge, and this in conjunction with sea level rise increases erosion potential in the delta area (Yang et al., 2017). In the recent past decades, sea level rise has been approximately $3 \mathrm{~mm} /$ year (Figure 4.10).

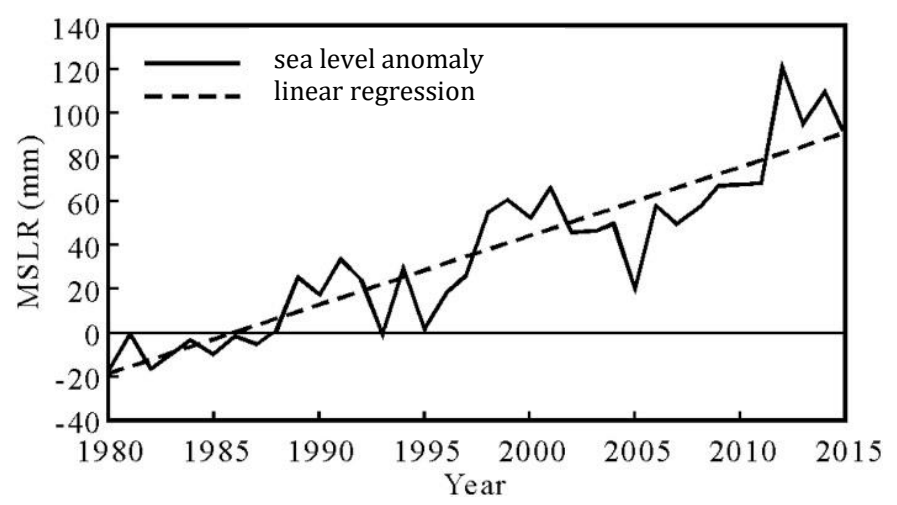

Figure 4.10: Mean sea level anomalies on the Chinese coast in 1980-2015 compared with the 1975-1993 mean (edited form Cheng \&Chen, 2017).

During the coming decades, the sea-level will continue to rise. The estimates of the magnitude of the rise vary from study to study. In the case of global warming of $2^{\circ} \mathrm{C}$, the global sea level rise is estimated to be slightly over $20 \mathrm{~cm}$ (90\% confidence limits 15-33 $\mathrm{cm})$. If warming is $4^{\circ} \mathrm{C}$, the sea level would rise more than $60 \mathrm{~cm}(90 \%$ confidence limits 39-124 cm) (Jevreva et al., 2016). Globally, the sea level rise varies from location to 
location, but according to Jevereva et al. (2016), for the Chinese coast the values are close to global mean. Sea level rise will increase coastal erosion, saltwater intrusion and storm surge intensity in the delta area. As well, the arrival time of tidal bores becomes earlier under sea-level rise and the height of bores and the velocities at the surface and bottom layers may increase (Wang et al, 2018).

\section{Concluding remarks}

This report deals with projected climatic changes in four areas of operation of the UPMKymmene company: Finland, southern Germany, Uruguay and eastern China. The implications of the projected changes for forestry, including forest growth and productivity and possible climate change induced disturbances are discussed as well. In the Introduction, the main natural and anthropogenic factors inducing changes in climate are examined, along with the methods used to assess the future changes. The main quantitative findings of the work are listed in the Executive summary in the beginning of the report and are therefore not replicated here.

In many cases, inter-model differences in the simulated responses are fairly large. Although all the models analyzed simulate higher temperatures for the future, the degree of warming varies quite a lot among the models. For many other climate variables, e.g., precipitation, even the sign of the future change is usually more or less uncertain. Even so, in the regions examined mean precipitation is more likely to increase than decrease, with the exception of southern Germany in summer and early autumn, Uruguay in Southern Hemisphere winter and spring and China in late autumn. Rising temperatures act to enhance evaporation, and consequently drought risks may exacerbate despite modest increases in precipitation. Actually, in many regions both the risks of drought and floods are increased owing to the larger fluctuability of precipitation. In some seasons both the intense rainfall events and dry periods are projected to become more severe.

In general, forest resources have been increasing in Europe. Especially in Northern Europe, forests have benefitted of the warmer climate and increased $\mathrm{CO}_{2}$ concentration in the atmosphere. During the coming decades, this positive development may at least partly be cancelled due to potentially increasing disturbances. For example, drought, fire and new pests may harm the forests. The role of forests as a carbon sink is an important aspect in the context of climate change mitigation activities. The key question is what climate smart forestry is; how forest can be utilized in a sustainable way but simultaneously maintaining or increasing their role as carbon sinks. Vivid discussion on the amount of sustainable use of forests is foreseen to continue in Finland but also elsewhere in Europe.

If global climate policy proves to be successful, it is possible that future changes in climate will be weaker than those based on the intermediate RCP4.5 scenario discussed in this report. On the other hand, in that case rapid restrictions of the greenhouse gas emissions are required globally, which evidently substantially influences the prerequisites of operations in heavy industry. 


\section{References}

Ala-Ilomäki, J., Högnäs, T., Lamminen, S. and Sirén, M. 2011. Equipping a conventional wheeled forwarder for peatland operations. International Journal of Forest Engineering, 22, 7-13.

Annila, E. 1969. Influence of temperature upon the development and voltinism of Ips typographus L. (Coleoptera, Scolytidae). Annales Zoologici Fennici, 6, 161-207.

Asikainen, A., Viiri, H., Neuvonen, S., Nevalainen, S., Lintunen, J., Laturi, J., Uusivuori, J., Venäläinen, A., Lehtonen, I. and Ruosteenoja, K. 2019. Ilmastonmuutos ja metsätuhot - analyysi ilmaston lämpenemisen seurauksista Suomen osalta. The Finnish Climate Change Panel, Helsinki, 76 pp. [in Finnish]

Bejer, B. 1988. The nun moth in European spruce forests. In: Berrymann, A.A. (ed.) Dynamics of forest insect populations, patterns, causes, and implications. Plenum Press, New York, NY, pp. 211-231.

Bengtsson, A. and Nilsson, C. 2007. Extreme value modelling of storm damage in Swedish forests. Natural Hazards and Earth System Sciences, 7, 515-521.

Bowman, D., Balch, K., Artaxo, P., Bond, W., Carlson, J., Cochrane, M., D’Antonio, C., DeFries, R., Doyle, J., Harrison, S., Johnston F., Keeley, J., Krawchuk, M., Kull, C., Marston, J., Moritz, M., Prentice, C., Roos, C., Scott, A., Swetnam, T., Der Werf, G. and Pyne, S. 2009. Fire in the Earth system. Science, 324, 481-484.

Chen, C., Park, T., Wang, X., Piao, S., Xu, B., Chaturvedi, R., Fuchs, R., Brovkin, V., Ciais, P., Fensholt, R., Tømmervik, H., Bala, G., Zhun, Z., Nemani, R. and Myneni, R. 2019. China and India lead in greening of the world through land-use management. Nature Sustainability, 2(128), p.122-129, https://doi.org/10.1038/s41893-019-0220-7.

Cheng, H.-Q. and Chen, J.-Y. 2017. Adapting cities to sea level rise: A perspective from Chinese deltas. Advances in Climate Change Research, 8(2017), 130-136.

Christiansen, E. and Bakke, A. 1988. The spruce bark beetle of Eurasia. In: Berryman, A.A. (ed.) Dynamics of forest insect populations, patterns, causes, and implications. Plenum Press, New York, NY, pp. 480-505.

EEA, 2016a. EEA Report No 5/2016, European forest ecosystems, State and trends. European Environment Agency (doi:10.2800/964893).

EEA, 2016b. Mapping and assessing the condition of Europe's ecosystems: progress and challenges, EEA Technical report No 3/2016, European Environment Agency.

EEA, 2017. EEA Report No 1/2017, Climate change, impacts and vulnerability in Europe 2016. An indicator-based report. European Environment Agency (doi:10.2800/534806).

Elkinton, J.S. and Liebhold, A.M. 1990. Population dynamics of gypsy moth in North America. Annual Review of Entomology, 35, 571-596.

Eronen, M. 1991. Jääkausien jäljillä. Tähtitieteellinen yhdistys Ursa, Helsinki, $271 \mathrm{~s}$.

Esseen, P.A., Ehnström, B., Ericson, L. and Sjöberg, K. 1997. Boreal forests. Ecological Bulletins, 46, 16-47.

Fält-Nardmann, J.J.J., Ruohomäki, K., Tikkanen, O.-P. and Neuvonen, S. 2018. Cold hardiness of Lymantria monacha and L. dispar (Lepidoptera: Erebidae) eggs to extreme winter temperatures: implications for predicting climate change impacts. Ecological Entomology, 43, 422-430.

Flannigan, M., Stocks, B., Turetsky, M. and Wotton, M. 2009. Impacts of climate change on fire activity and fire management in the circumboreal forest. Global Change Biology, 15, 549-560.

Food and Agriculture Organization of The United Nations (FAO), 2016. GLOBAL FOREST RESOURCES ASSESSMENT 2015, How are the world's forests changing? Second edition.

FOREST EUROPE, 2015. State of Europe's Forests 2015. 
Ganteaume, A., Camia, A., Jappiot, M., San-Miguel-Ayanz, J., Long-Fournel, M. and Lampin, C. 2013. A review of the main driving factors of forest fire ignition over Europe. Environmental Management, 51, 651-662.

Global Forest Watch, 2019. Tree cover gain in Uruguay compared to other areas. Accessed on 29.3.2019 from www.globalforestwatch.org.

Gonçalves, A.C. and Sousa, A.M.O. 2017. The fire in the Mediterranean region: a case study of forest fires in Portugal. In: Fuerst-Bjeliš, B. (ed.) Mediterranean identities: environment, society, culture. InTech, Rijeka, pp. 305-335.

Gregow, H., Ruosteenoja, K., Juga, I., Näsman, S., Mäkelä, M., Laapas, M. and Jylhä, K. 2011. Lumettoman maan routaolojen mallintaminen ja ennustettavuus muuttuvassa ilmastossa (Modelling and predictability of soil frost depths of snow-free ground under climate-model projections). Finnish Meteorological Institute, Reports 2011:5, 45 pp. [in Finnish with English abstract]

Grodzki, W. 1999. Phytosanitary situation in Polish mountain forests in 1998 and forecast for 1999. In: Forster, B., Knizek, M. and Grodzki, W. (eds.) Methodology of forest insect and disease survey in Central Europe. Proceedings of the Second Workshop of the IUFRO Working Party 7.03.10, 20-23 April 1999, Sion-Châteauneuf, Switzerland. Swiss Federal Institute for Forest, Snow and Landscape Research, Birmensdorf, Switzerland, pp. 30-35.

Groenemeijer, P., Vajda, A., Lehtonen, I., Kämäräinen, M., Venäläinen, A., Gregow, H., Becker, N., Nissen, K., Ulbrich, U., Morales Nápoles, O., Paprotny, D. and Púčik, T. 2016. Present and future probability of meteorological and hydrological hazards in Europe. European Severe Storms Laboratory, $165 \mathrm{~s}$.

Gu, H., Yu, Z., Wang, G., Wang, J., Ju, Q., Yang., C and Fan., C. 2015. Impact of climate change on hydrological extremes in the Yangtze River Basin, China. Stoch Environ Res Risk Assess 29:693-707, DOI 10.1007/s00477-014-0957-5

Gu, H., Yu, Z., Yang, C. and Ju, Q. 2018. Projected changes in hydrological extremes in the Yangtze River basin with an ensemble of regional climate simulations. Water, 10, 1279; doi:10.3390/w10091279.

Hansen, M. C., P. V. Potapov, R. Moore, M. Hancher, S. A. Turubanova, A. Tyukavina, D. Thau, S. V. Stehman, S. J. Goetz, T. R. Loveland, A. Kommareddy, A. Egorov, L. Chini, C. O. Justice, and J. R. G. Townshend. 2013. High-Resolution Global Maps of 21st-Century Forest Cover Change. Science 342 (15 November): 850-53. Data available on-line from:http://earthenginepartners.appspot.com/science-2013-globalforest. Accessed through Global Forest Watch on [date]. www.globalforestwatch.org

Hantula, J., Müller, M.M. and Uusivuori, J. 2014. International plant trade associated risks: Laissez-faire or novel solutions. Environmental Science \& Policy, 37, 158-160.

Hareau, A., Hofstadter, R. and Saizar, A., 1999. Vulnerability to climate change in Uruguay: potential impacts on the agricultural and coastal resource sectors and response capabilities. Clim Res 12: 185-193.

Haynes, K., Allstadt, A. and Klimetzek, D. 2014. Forest defoliator outbreaks under climate change: effects on the frequency and severity of outbreaks of five pine insect pests. Global Change Biology, 20, 2004-2018.

Heikinheimo, O. 1920. Suomen lumituhoalueet ja niiden metsät. Metsätieteellisen koelaitoksen julkaisuja 3. [in Finnish]

Heino, E. and Pouttu, A. 2014. Metsätuhot vuonna 2013. Metlan työraportteja, 295, 2425. [in Finnish]

Hlásny, T., Zajíčková, L., Turčáni, M., Holuša, J. and Sitková, Z. 2011. Geographical variability of spruce bark beetle development under climate change in the Czech Republic. Journal of Forest Science, 57, 242-249. 
Hlásny, T., Trombik, J., Holuša, J., Lukášová, K., Grendár, M., Turčáni, M., Zúbrik, M., Tabakovič-Tošič, M., Hirka, A., Buksha, I., Modlinger, R., Kacprzyk, M. and Csóka, G. 2016. Multi-decade patterns of gypsy moth fluctuations in the Carpathian Mountains and options for outbreak forecasting. Journal of Pest Science, 89, 413-425.

IPCC, 2013. Climate Change 2013. The physical science basis. Contribution of Working Group I to the Fifth Assessment Report of the Intergovernmental Panel on Climate Change. Cambridge University Press, Cambridge, U.K., 1535 pp. [Stocker, T.F., D. Qin, G.-K. Plattner, M. Tignor, S.K. Allen, J. Boschung, A. Nauels, Y. Xia, V. Bex and P.M. Midgley (eds.)].

IPCC. 2018. Global Warming of $1.5^{\circ} \mathrm{C}$ http://www.ipcc.ch/report/sr15/

Jalkanen, R. and Konôpka, B. 1998. Snow-packing as a potential harmful factor on Picea abies, Pinus sylvestris and Betula pubescens at high altitude in northern Finland. European Journal of Forest Pathology, 28, 373-382.

Jevrejeva, S., Jackson, L.P., Riva, R.E., et al., 2016. Coastal sea level rise with warming above $2{ }^{\circ}$ C. Proc. Natl. Acad. Sci. U. S. A. 113 (47), 13342-13347.

Kaakkurivaara, T., Vuorimies, N., Kolisoja, P. and Uusitalo, J. 2015. Applicability of portable tools in assessing the bearing capacity of forest roads. Silva Fennica, 49, article id 1239.

Kalliokoski, T., Heinonen, T., Holder, J., Lehtonen, A., Mäkelä, A., Minunno, F., Ollikainen, M., Packalen, T., Pelroniemi, M., Pukkala, T., Salminen, O., Schelhaas, M.J., Seppälä, J. and Kanninen, M. 2019. Skenaarioanalyysi metsien kehitystä kuvaavien mallien ennusteiden yhtäläisyyksistä ja eroista. Suomen Ilmastopaneeli, Raportti 2/2019.

Kellomäki, S., Peltola H., Nuutinen T., Korhonen K. T., \& Strandman, H. 2008. Sensitivity of managed boreal forests in Finland to climate change, with implications for adaptive management. Philosophical Transactions of the Royal Society B: Biological Sciences, Volume 363, Issue 1501: 2339-2349. http://dx.doi.org/10.1098/rstb.2007.2204.

Kellomäki, S., Maajärvi, M., Strandman, H., Kilpeläinen, A. and Peltola, H. 2010. Model computations on the climate change effect on snow cover, soil moisture and soil frost in the boreal conditions over Finland. Silva Fennica, 44, 213-233.

Kellomäki, S., Strandman, H., Heinonen, T., Asikainen, A., Venäläinen, A. and Peltola, H., 2018. Temporal and Spatial Change in Diameter Growth of Boreal Scots Pine, Norway Spruce, and Birch under Recent-Generation (CMIP5) Global Climate Model Projections for the 21st Century. Forests 2018, 9, 118; doi:10.3390/f9030118

Korhonen, K.T., Ihalainen, A., Ahola, A., Heikkinen, J., Henttonen, H.M., Hotanen, J.-P., Nevalainen, S., Pitkänen, J., Strandström, M. and Viiri, H. 2017. Suomen metsät 20092013 ja niiden kehitys 1921-2013. Luke's series focusing on natural resources and the bioeconomy 59/2017. Natural Resources Institute Finland, Helsinki, 86 pp.

Krejzar, T. 2018. Bark beetle outbreak in the Czech Republic: challenges and solutions. European Network INTEGRATE seminar on managing bark beetle impacts on forest, Poland 25-27 June 2018.

Långström, B., Lindelöw, Å., Schroeder, M., Björklund, N. and Öhrn, P. 2009. The spruce bark beetle outbreak in Sweden followinf the January-storms in 2005 and 2007. Proceedings of a workshop on Insects and Fungi in Storm Areas. Štrbské Pleso, Slovakia, 15-19 September 2008.

Länsstyrelsen i Västmanlands län. 2015. Skogsbranden i Västmanland 2014. En dokumentation utgiven av Länsstyrelsen i Västmanlands län. Länstyrelsen i Västmanlands län, Västerås, 31 pp. [in Swedish]

Lehtonen, I., Hoppula, P., Pirinen, P. and Gregow, H. 2014. Modelling crown snow loads in Finland: a comparison of two methods. Silva Fennica, 48, article id 1120. 
Lehtonen, I., Venäläinen, A., Kämäräinen, M., Peltola, H. and Gregow, H. 2016a. Risk of large-scale fires in boreal forests of Finland under changing climate. Natural Hazards and Earth System Sciences, 16, 239-253.

Lehtonen, I., Kämäräinen, M., Gregow, H., Venäläinen, A. and Peltola, H. 2016b. Heavy snow loads in Finnish forests respond regionally asymmetrically to projected climate change. Natural Hazards and Earth System Sciences, 16, 2259-2271.

Lehtonen, I., Venäläinen, A., Kämäräinen, M., Asikainen, A., Laitila, J., Anttila, P. and Peltola, H. 2019. Projected decrease in wintertime bearing capacity on different forest and soil types in Finland under a warming climate. Hydrology and Earth System Sciences, 23, 1611-1631.

Lehtonen, I., and Jylhä, K., 2019. Tendency towards a more extreme precipitation climate in the Coupled Model Intericomparison Project Phase 5 models. Atmospheric Science Letters, doi:10.1002/asl.895.

Leinonen, R., Pöyry, J., Söderman, G. and Tuominen-Roto, L. 2017. Suomen yöperhosyhteisöt muutoksessa - valtakunnallisen yöperhosseurannan keskeisiä tuloksia 1993-2012. Baptria, 42, 74-92.

Lier, M., Korhonen,K.T., Packalen, T., Aarne, M., Tuomainen, T., Viitanen, J., Mutanen, A., Vaahtera, E. and Hyvärinen, J. (LUKE), 2018. Finland's forests, https://www.luke.fi/en/natural-resources/forest/forest-resources-and-forestplanning/finnish-forests-in-europe-in-2015/

Lilja, A., Rytkönen, A., Hantula, J., Müller, M., Parikka, P., Kurkela, T. 2011. Introduced pathogens found on ornamentals, strawberry and trees in Finland over the past 20 years. Agricultural and food science, 20, 74-85.

Liu, S., Zhang, Y., Zhang, Y. and Ding, Y., 2009. Estimation of glacier runoff and future trends in the Yangtze River source region, China, Journal of Glaciology, Vol. 55, No. 190.

Luomaranta, A., K. Ruosteenoja, K. Jylhä, H. Gregow, J. Haapala, and A. Laaksonen, 2014. Multimodel estimates of the changes in the Baltic Sea ice cover during the present century. Tellus A, 66, 22617, doi: http://dx.doi.org/10.3402/tellusa.v66.22617.

Marini, L., Økland, B., Jönsson, A.M., Bentz, B., Carroll, A., Forster, B., Grégoire, J.-C., Hurling, R., Nageleisen, L.M., Netherer, S., Ravn, H.P., Weed, A. and Schroeder, M. 2017. Climate drivers of bark beetle outbreak dynamics in Norway spruce forests. Ecography, 40, 1426-1435.

McManus, M. and Csóka, G. 2007. History and impact of gypsy moth in North America and comparison to recent outbreaks in Europe. Acta Silvatica \& Lignaria Hungarica, 3, 47-64.

Mei, L., Xue, Y., de Leeuw, G., Guang, J., Wang, Y., Li, Y., Xu, H., Yang, L., Hou, T., He, X., Wu, C., Dong, J. and Chen, Z. 2011. Integration of remote sensing data and surface observations to estimate the impact of the Russian wildfires over Europe and Asia during August 2010. Biogeosciences, 8, 3771-3791.

Migliavacca, M., Dosio, A., Camia, A., Hobourg, R., Houston-Durrant, T., Kaiser, J.W., Khabarov, N., Krasovskii, A.A., Marcolla, B., San Miguel-Ayanz, J., Ward, D.S. and Cescatti, A. 2013. Modeling biomass burning and related carbon emissions during the 21st century in Europe. Journal of Geophysical Research: Biogeosciences, 118, 17321747.

Munier, S., Carrer, D., Planque, C., Camacho, F., Albergel, C. and Calvet, J.-C., 2018. Satellite Leaf Area Index: Global Scale Analysis of the Tendencies Per Vegetation Type Over the Last 17 Years. Remote Sens., 10, 424; doi:10.3390/rs10030424.

Müller, M.M., Henttonen, H.M., Penttilä, R., Kulju, M., Helo, T. and Kaitera, J. 2018. Distribution of Heterobasidion butt rot in northern Finland. Forest Ecology and Management, 425, 85-91. 
Müller, M.M., Sievänen, R., Beuker, E., Meesenburg, H., Kuuskeri, J., Hamberg, L. and Korhonen, K. 2014. Predicting the activity of Heterobasidion parviporum on Norway spruce in warming climate from its respiration rate at different temperatures. Forest Pathology, 44, 325-336.

Neuvonen, S., Kullberg, J., Kämäräinen, M., Lehtonen, I., Nevalainen, S., Siljamo, P. and Venäläinen, A. 2018. Havununna ja lehtinunna - tulevaisuuden metsätuholaisiin on syytä varautua ennakolta. Luonnonvara- ja biotalouden tutkimus, 44/2018, 30-39. [in Finnish]

Nevalainen, S., Sirkiä, S., Peltoniemi, S. and Neuvonen, S. 2015. Vulnerability to pine sawfly damage decreases with site fertility but the opposite is true with Scleroderris canker damage; results from Finnish ICP Forests and NFI data. Annals of Forest Science, 72, 909-917.

Nykänen, M.-L., Peltola, H., Quine, C.P., Kellomäki, S. and Broadgate, M. 1997. Factors affecting snow damage of trees with particular reference to European conditions. Silva Fennica, 31, 193-213.

Petty, J.A. and Worrell, R. 1981. Stability of coniferous tree stems in relation to damage by snow. Forestry, 54, 115-128.

Piao, S., Ciais, P., Huang, Y., Shen, Z., Peng, S., Li, J., Zhou, L., Liu, H., Ma., Y., Ding, Y., Friedlingstein, P., Liu, C., Tan, K., Yu, Y., Zhang, T. and Fang, J., 2010. The impacts of climate change on water resources and agriculture in China. Nature 467, 4351, doi:10.1038/nature09364.

Pohjankukka, J., Riihimäki, H., Nevalainen, P., Pahikkala T., Ala-Ilomäki, J., Hyvönen, E, Varjo, J. and Heikkonen, J. 2016. Predictability of boreal forest soil bearing capacity by machine learning. Journal of Terramechanics, 68, 1-8.

Pouttu, A. and Annila, E. 2010. Kirjanpainajalla kaksi sukupolvea kesällä 2010. Metsätieteen aikakauskirja, 4/2010, 521-523.

Pukkala, T., Möykkynen, T., Thor, M., Rönnberg, J. and Stenlid, J. 2005. Modeling infection and spread of Heterobasidion annosum in even-aged Fennoscandian conifer stands. Canadian Journal of Forest Research, 35, 74-84.

Reyer, C., Lasch-Born P., Suckow F., Gutsch M., Murawski A., \& Pilz T. 2014. Projections of regional changes in forest net primary productivity for different tree species in Europe driven by climate change and carbon dioxide. Annals of Forest Science, Volume 71, Issue 2: 211-225. http://dx.doi.org/10.1007/s13595-013-0306-8

Reyer C., Bathgate S., Blennow K., Borges JG., Bugmann H., Delzon S., Faias S.P., Garcia-Gonzalo J., Gardiner, B., Gonzalez-Olabarria J.R., Gracia C., Hernández J.G., Kellomäki, S., Kramer K., Lexer M.J., Lindner, M., van der Maaten, E., Maroschek M., Muys B., Nicoll B., Palahi M., Palma J. HN., Paulo J.A., Peltola H., Pukkala T., Rammer W., Ray D., Sabaté S., Schelhaas M.J., Seidl R., Temperli C., Tomé M., Yousefpour R., Zimmermann N.E., Hanewinkel M. 2017a. Are forest disturbances amplifying or cancelling out climate change-induced productivity changes in European forests? Environmental Research Letters 12(3), 034027.

Reyer, C., Adams, S., Albrech, T., Baarsch, F., Boit, A., Trujillo, N., Cartsburg, M., Coumou, D., Eden, A., Fernandes, E., Langerwisch, F., Marcus, R., Mengel, M., MiraSalama, D., Perette, M., Pereznieto, P., Rammig, A., Reinhard, J., Robinson, A., Rocha, M., Sakshewski, B., Schaeffer, M., Schleussner, C.-F., Serdeczny, O. and Thornicke, K., 2017b. Climate change impacts in Latin America and the Caribbean and their implications for development. Reg Environ Change (2017) 17:1601-1621, DOI 10.1007/s10113-015-0854-6.

Ruosteenoja, K., Räisänen, J., and Pirinen, P. 2011. Projected changes in thermal seasons and the growing season in Finland. International Journal of Climatology, 31, 14731487. 
Ruosteenoja, K., 2011. Miten ja miksi ilmasto muuttuu? Ilmastonmuutos käytännössä hillinnän ja sopeutumisen keinoja, A. Virtanen and L. Rohweder, Eds., Gaudeamus, chap. 3, 69-108.

Ruosteenoja, K., Jylhä, K., Kämäräinen, M., 2016a. Climate projections for Finland under the RCP forcing scenarios. Geophysica, 51, 17-50.

Ruosteenoja, K., J. Räisänen, A. Venäläinen, and M. Kämäräinen, 2016b. Projections for the duration and degree days of the thermal growing season in Europe derived from CMIP5 model output. International Journal of Climatology, 36, 3039-3055, doi:10.1002/joc.4535.

Ruosteenoja, K., Markkanen, T., Venäläinen, A., Räisänen, P. and Peltola, H., 2018. Seasonal soil moisture and drought occurrence in Europe in CMIP5 projections for the 21st century. Climate Dynamics, 50, 1177-1192, doi:10.1007/s00382-017-3671-4.

Ruosteenoja, K., A. Venäläinen, and T. Vihma, 2019. Projected changes in European and North Atlantic seasonal wind climate derived from CMIP5 simulations. Submitted to journal.

Schelhaas, M.-J., Nabuurs, G.-J. and Schuck, A. 2003. Natural disturbances in the European forests in the 19th and 20th centuries. Global Change Biology, 9, 1620-1633.

Schelhaas, M.-J., 2008. Impacts of natural disturbances on the development of European forest resources: application of model approaches from tree and stand levels to largescale scenarios. Dissertationes Forestales, 56, 28 p. https://doi.org/10.14214/df.56

Schlyter, P., Stjernquist, I., Bärring, L, Jönsson, A.M. and Nilsson, C. 2006. Assessment of the impacts of climate change and weather extremes on boreal forests in northern Europe, focusing on Norway spruce. Climate Research, 31, 75-84.

Schroeder, L.M. and Eidmann, H.H. 1993. Attacks of bark- and wood-boring Coleoptera on snow-broken conifers over a two-year period. Scandinavian Journal of Forest Research, 8, 257-265.

Shen, Y., Wang, G., Wang, G., Pu, J. and Wang, X., 2009. Impacts of climate change on glacial water resources and hydrological cycles in the Yangtze River source region, the Qinghai-Tibetan Plateau, China: A Progress Report. Sciences in Cold and Arid Regions, , 1(6): 0475-0495

Seidl, R., Rammer, W., Jäger, D. and Lexer, M.J. 2008. Impact of bark beetle (Ips typographus L.) disturbance on timber production and carbon sequestration in different management strategies under climate change. Forest Ecology and Management, 256, 209-220.

Seidl, R., Schelhaas, M.-J., Lindner, M. and Lexer, M. 2009. Modelling bark beetle disturbanes in a large scale forest scenario model to assess climate change impacts and evaluate adaptive management strategies. Regional Environmental Change, 9, 101109.

Seidl, R., Schelhaas, M.-J. J., Rammer, W., and Verkerk, P. J., 2014. Increasing forest disturbances in Europe and their impact on carbon storage. Nature Climate Change, 4(9), 806-810. https://doi.org/10.1038/nclimate2318

Siitonen, J. and Pouttu, A. 2014. Kirjanpainajatuhot Rörstrandin vanhojen metsien suojelualueella sekä ympäröivissä talousmetsissä Sipoossa. Metsätieteen aikakauskirja, 3/2014, 183-193.

Sirén, M., Ala-Ilomäki, J., Mäkinen, H., Lamminen, S. and Mikkola, T. 2013. Harvesting damage caused by thinning of Norway spruce in unfrozen soil. International Journal of Forest Engineering, 24, 60-75.

Solantie, R. 1994. Effects of weather and climatological background on snow damage of forests in Southern Finland in November 1991. Silva Fennica, 28, 203-211. 
Svenson, G. and Fjeld, D. 2016. The impact of road geometry and surface roughness on fuel consumption of logging trucks. Scandinavian Journal of Forest Research, 31, 526536.

Turco, M., Rosa-Cánovas, J.J., Bedia, J., Jerez, S., Montávez, J.P. Llasat, M.C. and Provenzale, A. 2018. Exacerbated fires in Mediterranean Europe due to anthropogenic warming projected with non-stationary climate-fire models. Nature Communications, 9, article number 3821.

Taylor, K. E., R. J. Stouffer, and G. A. Meehl, 2012. An overview of CMIP5 and the experiment design. Bulletin of the American Meteorological Society, 93, 485-498, doi:10.1175/BAMS-D-11-00094.1.

Valinger, E., Lundqvist, L. and Brandel, G. 1994. Wind and snow damage in a thinning and fertilisation experiment in Pinus sylvestris. Scandinavian Journal of Forest Research, 9, 129-134.

Van Wagner, C.E. 1987. Development and structure of the Canadian Forest Fire Weather Index System. Forestry Technical Report 35, Canadian Forest Service, Ottawa, ON, 37 pp.

van Vuuren, D. P., et al., 2011. The representative concentration pathways: an overview. Climatic Change, 109, 5-31, doi:10.1007/s10584-011-0148-z.

Veijalainen, N., K. Ruosteenoja, J. Uusikivi, A. Mäkelä, and B. Vehviläinen, 2018. Ilmastonmuutos ja virtaamien muuttuminen Kemi-, Kymi- ja Lieksanjoen alueilla (climate change and changes in discharges in Kemi-, Kymi- and Lieksanjoki areas). Tech. Rep. 27/2018, Finnish Environment Institute, 43 pp.

Venäläinen, A., Tuomenvirta, H., Heikinheimo, M., Kellomäki, S., Peltola, H., Strandman, H. and Väisänen, H. 2001. Impact of climate change on soil frost under snow cover in a forested landscape. Climate Research, 17, 63-72.

Viiri, H., Ahola, A., Ihalainen, A., Korhonen, K.T., Muinonen, E., Parikka, H. and Pitkänen, J. 2011. Kesän 2010 ukkosmyrskyt ja niistä seuraava hyönteistuhoriski. Metsätieteen aikakauskirja 3/2011, 221-225.

Virtanen, T., Neuvonen, S., Nikula, A., Varama, M. and Niemelä, P. 1996. Climate change and the risks of Neodiprion sertifer outbreaks on Scots pine. Silva Fennica, 30, 169177.

Vivchar, A. 2011. Wildfires in Russia in 2000-2008: estimates of burnt areas using the satellite MODIS MCD45 data. Remote Sensing Letters, 2, 81-90.

Voolma, K., Nilson, T. and Pilt, E. 2014. Okkalainelane Euroopas, Saaremaal ja satelliidipildil. Eesti Mets, 2, 38-43. [in Estonian]

Wallenius, T. 2011. Major decline in fires in coniferous forests - reconstructing the phenomenon and seeking for the cause. Silva Fennica, 45, 139-155.

Wang, S. and Zhang, Z., 2011. Effects of climate change on water resources in China. Clim Res, 47, 77-82. doi: 10.3354/cr00965.

Wang, Q.-S., Pan, C.-H. and Zhang G..Z., 2018. Impact of and adaptation strategies for sea-level rise on Yangtze River Delta. Advances in Climate Change Research 9, 154160. doi.org/10.1016/j.accre.2018.05.005.

Wang, G., Cai, W., Gan, B., Wu, L., Santoso, A., Lin, X., Chen, Z. and McPhade, M., 2017. Continued increase of extreme El Niño frequency long after $1.5^{\circ} \mathrm{C}$ warming stabilization, Nature Climate Change 7, p. 568, DOI: 10.1038/NCLIMATE3351.

Weseloh, R.M. 2003. People and the gypsy moth: a story of human interactions with an invasive species. American Entomologist, 49, 180-190.

WMO, 1989. Calculation of monthly and annual 30-year standard normals. World Meteorological Organization, Geneva, 11 pp., WCDP-No. 10, WMOTD/ No. 341. 
Woodward, S., Stenlid, J., Karjalainen, R. and Hüttermann, A. 1998. Heterobasidion annosum. Biology, ecology, impact and control. CAB International, Wallingford, 589 pp.

Wypych, A., Sulikowska, A., Ustrnul, Z., and Czekierda, D. 2017. Variability of growing degree days in Poland in response to ongoing climate changes in Europe. International Journal of Biometeorology, 61, 49-59.

Yang, H., Yang, S., Xu, K., Wu, H., Shi, B., Zhu, Q., Zhang, W. and Yang, Z., 2017. Erosion potential of the Yangtze delta under sediment starvation and climate change. Scientific reports, 7:10535. DOI:10.1038/s41598-017-10958-y.

Yu, Z., Gu, H., Wang, J., Xia, J. and Lu, B., 2018. Effect of projected climate change on the hydrological regime of the Yangtze River basin, China. Stoch Environ Res Risk Assess, 32:1-16. Doi:10.1007/s00477-017-1391-2.

Zubizarreta-Gerendiain A, Pukkala T, Peltola H., 2017. Effects of wind damage on the optimal management of boreal forests under current and changing climatic conditions. Canadian Journal of Forest Research 47(2):246-256. doi:10.1139/cjfr-2016-0226.

Öhrn, P., Långström, B., Lindelöw, Å. and Björklund, N. 2014. Seasonal flight patterns of Ips typographus in southern Sweden and thermal sums required for emergence. Agricultural and Forest Entomology, 16, 1-23. 


\section{Appendix A: Technical information about the model data and the analysis methods}

A.1 Climate model data

In this report, estimates for future climatic changes were inferred from simulations performed with 28 global climate models (Table A1). The output data of the models have been downloaded from the international data archive hosted by the Coupled Model Intercomparison Project (CMIP) (Taylor et al., 2012). The model ensemble is nearly the same that has been utilized in the elaboration of the Fifth Assessment Reports of the Intergovernmental Panel on Climate Change (IPCC). More detailed information about the models is available in Table 9.A.1 of IPCC (2013).

Table A1. Global climate models used in creating the climate projections. The first and second columns state the model acronym and the country of origin; the EC-EARTH model has been developed by a consortium of multiple European countries. The remaining columns show the availability of model data under the RCP4.5 scenario for temperature, precipitation and incident solar radiation $(T+P+S)$, relative humidity $(R H)$, near-surface soil moisture (SOILM), geostrophic wind (VG), daily standard deviations of temperature and precipitation and precipitation indices (STDEV) and the growing season (GROW).

\begin{tabular}{llllllll} 
Model & Country & $\mathrm{T}+\mathrm{P}+\mathrm{S}$ & $\mathrm{RH}$ & SOILM & $\mathrm{VG}$ & STDEV & GROW \\
\hline MIROC5 & Japan & $\mathrm{X}$ & $\mathrm{X}$ & $\mathrm{X}$ & $\mathrm{X}$ & $\mathrm{X}$ & $\mathrm{X}$ \\
MIROC-ESM & Japan & $\mathrm{X}$ & $\mathrm{X}$ & $\mathrm{X}$ & $\mathrm{X}$ & $\mathrm{X}$ & $\mathrm{X}$ \\
MIROC-ESM-CHEM & Japan & $\mathrm{X}$ & $\mathrm{X}$ & $\mathrm{X}$ & & & $\mathrm{X}$ \\
MRI-CGCM3 & Japan & $\mathrm{X}$ & $\mathrm{X}$ & $\mathrm{X}$ & $\mathrm{X}$ & $\mathrm{X}$ & $\mathrm{X}$ \\
BCC-CSM1-1 & China & $\mathrm{X}$ & $\mathrm{X}$ & $\mathrm{X}$ & $\mathrm{X}$ & $\mathrm{X}$ & $\mathrm{X}$ \\
INMCM4 & Russia & $\mathrm{X}$ & $\mathrm{X}$ & $\mathrm{X}$ & $\mathrm{X}$ & $\mathrm{X}$ & $\mathrm{X}$ \\
NorESM1-M & Norway & $\mathrm{X}$ & $\mathrm{X}$ & $\mathrm{X}$ & $\mathrm{X}$ & $\mathrm{X}$ & $\mathrm{X}$ \\
NorESM1-ME & Norway & $\mathrm{X}$ & $\mathrm{X}$ & $\mathrm{X}$ & & & \\
HadGEM2-ES & U.K. & $\mathrm{X}$ & $\mathrm{X}$ & $\mathrm{X}$ & $\mathrm{X}$ & $\mathrm{X}$ & $\mathrm{X}$ \\
HadGEM2-CC & U.K. & $\mathrm{X}$ & $\mathrm{X}$ & $\mathrm{X}$ & $\mathrm{X}$ & $\mathrm{X}$ & $\mathrm{X}$ \\
MPI-ESM-LR & Germany & $\mathrm{X}$ & & $\mathrm{X}$ & $\mathrm{X}$ & $\mathrm{X}$ & $\mathrm{X}$ \\
MPI-ESM-MR & Germany & $\mathrm{X}$ & & $\mathrm{X}$ & $\mathrm{X}$ & $\mathrm{X}$ & $\mathrm{X}$ \\
CNRM-CM5 & France & $\mathrm{X}$ & $\mathrm{X}$ & $\mathrm{X}$ & $\mathrm{X}$ & $\mathrm{X}$ & $\mathrm{X}$ \\
IPSL-CM5A-LR & France & $\mathrm{X}$ & $\mathrm{X}$ & $\mathrm{X}$ & $\mathrm{X}$ & $\mathrm{X}$ & $\mathrm{X}$ \\
IPSL-CM5A-MR & France & $\mathrm{X}$ & $\mathrm{X}$ & $\mathrm{X}$ & $\mathrm{X}$ & $\mathrm{X}$ & $\mathrm{X}$ \\
CMCC-CM & Italy & $\mathrm{X}$ & & $\mathrm{X}$ & $\mathrm{X}$ & $\mathrm{X}$ & $\mathrm{X}$ \\
CMCC-CMS & Italy & $\mathrm{X}$ & & $\mathrm{X}$ & $\mathrm{X}$ & $\mathrm{X}$ & $\mathrm{X}$ \\
GFDL-CM3 & U.S.A. & $\mathrm{X}$ & $\mathrm{X}$ & $\mathrm{X}$ & $\mathrm{X}$ & $\mathrm{X}$ & $\mathrm{X}$ \\
GFDL-ESM2M & U.S.A. & $\mathrm{X}$ & $\mathrm{X}$ & $\mathrm{X}$ & $\mathrm{X}$ & $\mathrm{X}$ & $\mathrm{X}$ \\
GISS-E2-R & U.S.A. & $\mathrm{X}$ & $\mathrm{X}$ & $\mathrm{X}$ & & & $\mathrm{X}$ \\
GISS-E2-H & U.S.A. & $\mathrm{X}$ & $\mathrm{X}$ & $\mathrm{X}$ & & & \\
NCAR-CCSM4 & U.S.A. & $\mathrm{X}$ & $\mathrm{X}$ & & $\mathrm{X}$ & $\mathrm{X}$ & $\mathrm{X}$ \\
NCAR-CESM1-CAM5 & U.S.A. & $\mathrm{X}$ & $\mathrm{X}$ & $\mathrm{X}$ & & & \\
NCAR-CESM1-BGC & U.S.A. & $\mathrm{X}$ & $\mathrm{X}$ & $\mathrm{X}$ & & & \\
CanESM2 & Canada & $\mathrm{X}$ & $\mathrm{X}$ & $\mathrm{X}$ & $\mathrm{X}$ & $\mathrm{X}$ & $\mathrm{X}$ \\
ACCESS1-0 & Australia & $\mathrm{X}$ & $\mathrm{X}$ & $\mathrm{X}$ & $\mathrm{X}$ & $\mathrm{X}$ & $\mathrm{X}$ \\
ACCESS1-3 & Australia & $\mathrm{X}$ & $\mathrm{X}$ & $\mathrm{X}$ & & & \\
EC-EARTH & Europe & $\mathrm{X}$ & & & $\mathrm{X}$ & $\mathrm{X}$ & $\mathrm{X}$ \\
& & & & & & &
\end{tabular}

The future evolution of the time-mean surface air temperature, precipitation and solar radiation was simulated by all of the 28 models. For the other quantities examined, by contrast, data were not available from the entire model ensemble. Accordingly, near surface soil moisture was analyzed from 26 models and relative humidity and the growing season length from 23 models. Calculating the temporal variations of temperature and precipitation and the precipitation indices requires data at a daily level, which was available from 21 models only (Table A1). Daily data was likewise needed in constructing wind speed projections. 
The true near-surface wind speeds are influenced, in addition to meteorological conditions, by the properties of the underlying surface. In forests, for instance, winds are consistently far weaker than over an open land or sea. In some models, the modelled surface conditions vary quite arbitrarily in the course of the model run, and thereby, it is hard to obtain reliable projections for wind speed changes directly from the modelsimulated wind data. Therefore, we have focused on the so-called geostrophic wind speeds that can be derived from the horizontal distribution of surface pressure. Geostrophic winds are relevant only in extratropical latitudes, and they mainly reflect winds related to largescale weather systems.

Model simulations were forced by the observation-derived "historical" greenhousegas concentrations up to the year 2005, after which the concentrations were adopted from the selected RCP scenario. We analyzed model output data up to the year 2099 or 2100 , which constitute the termination years for most of the model runs.

Many climate models provide data from multiple parallel runs for the individual RCP scenarios. Parallel runs are forced by identical greenhouse gas and aerosol concentrations but the initial conditions employed in the run diverge. Using data from parallel runs helps to reduce the uncertainty induced by internal natural variability of the climate system. Information about the parallel-run data available for the 28 models is given in Table 1 of Ruosteenoja et al. (2016).

\section{A.2 Processing of the model output}

The computational grid varies among the 28 climate models. Therefore, prior to calculating the multi-model statistics, all model data were interpolated bi-linearly onto a common $2.5 * 2.5$ degree latitude-longitude grid. Climate change projections are given for tridecadal periods. The 30 -year averaging period, consistent with the recommendations of WMO (1989) to calculate climatological standard normals, is a reasonable compromise; such a period rather representatively contains years with different weather conditions, but climate does not change too much within the period.

Future changes in the climate variables were calculated relative to the baseline-period 1971-2000 mean. In calculating the multi-model means and standard deviations for the simulated changes, all 28 models were weighted equally, with the exception that no individual research centre was given more than two "votes". Accordingly, halved weight coefficients were given for MIROC-ESM, MIROC-ESM-CHEM, NCAR-CESM1-CAM5 and NCAR-CESM1-BGC, while the remaining models were weighted by unity. Daily data were analyzed from a more limited set of models in which no centre is represented more than twice (Table A1).

After calculating the standard deviations representing the scatter of the changes simulated by the various model runs, the $90 \%$ uncertainty intervals for the change were calculated by using the normality approximation.

Temporal standard deviations of temperature and precipitation were first calculated separately for all 12 calendar months from a time series containing $30 *$ (28 to 31 ) days for the individual months. This was done separately for all 21 models using only one parallel run. Then, changes relative to 1971-2000 were determined both in the absolute and percentage terms, and these were used to calculate both the multi-model mean and inter-model scatter for the STD change.

The thermal growing season begins in spring when daily mean temperature rises "permanently" above $5^{\circ} \mathrm{C}$. More precisely, after the onset date there has to be less summed daily-mean temperature anomaly below than above this threshold temperature (see Figure 2 of Ruosteenoja et al., 2016b). The termination of the growing season in autumn is defined analogously. The effective temperature sum (also termed growing degree days) of the growing season is calculated by summing all the deviations above $5^{\circ} \mathrm{C}$ in the daily mean 
temperature from the onset till the termination of the growing season. Growing degree days give a reasonable picture of the thermal conditions of the growing season for plants adjusted to live in the boreal climate zone (e.g., in Finland). For heat-loving plants growing in warm climate, the concept is not relevant since those plants require temperatures far higher than $5^{\circ} \mathrm{C}$ for their growth.

If the reader is interested in further details of the analysis methods, the following references provide additional information: Ruosteenoja et al. (2016a) for the time-mean changes in temperature, precipitation and solar radiation, including the multi-model mean changes as well as the uncertainty intervals; Ruosteenoja et al. (2018) for soil moisture; Lehtonen and Jylhä (2019) for the precipitation indices; Ruosteenoja et al. (2019) for the geostrophic wind speeds; Ruosteenoja et al. (2016b) for growing season projections; Veijalainen et al. (2018) for hydrological changes in selected Finnish rivers. 
FINNISH METEOROLOGICAL INSTITUTE

Erik Palménin aukio 1

P.O. Box 503

FI-00560 HELSINKI

tel. +358 295391000

WWW.FMI.FI

FINNISH METEOROLOGICAL INSTITUTE REPORTS 2019:3

ISSN 0782-6079

ISBN 978-952-336-084-6 (paperback)

ISBN 978-952-336-085-3 (pdf)

https://doi.org/10.35614/isbn.9789523360853

Edita Prima Oy

Helsinki 2019
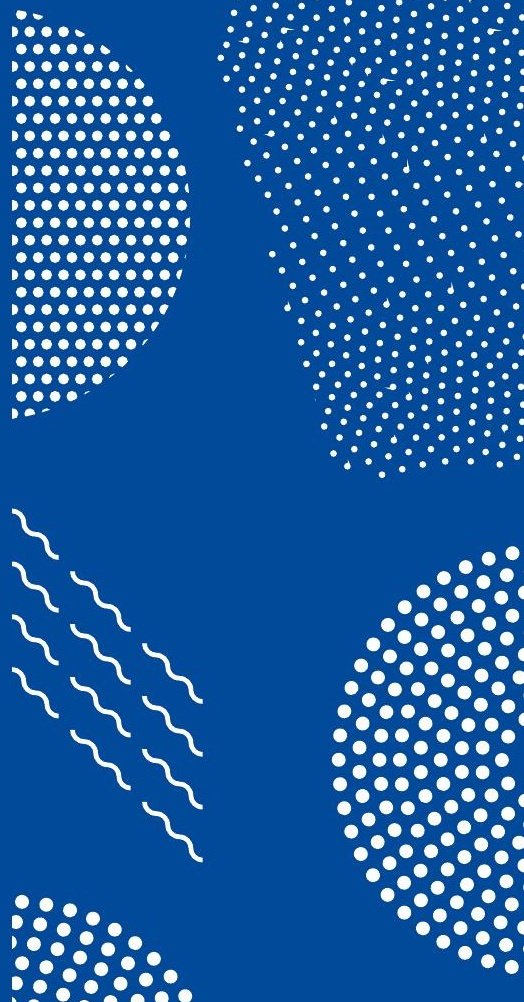